\title{
Experiências com desenvolvimento ágil
}

\author{
Dairton Luiz Bassi Filho
}

\author{
DisSERTAÇÃO APRESENTADA AO \\ Instituto de MATEMÁtica E Estatística DA \\ Universidade de SÃo PAUlo PARA \\ OBTENÇÃo DO TÍTULO DE \\ Mestre em CiÊnCIAS
}

Área de Concentração: Ciência da Computação
Orientador: Prof. Dr. Eduardo Colli

São Paulo, março de 2008 


\title{
Experiências com desenvolvimento ágil
}

\author{
Este exemplar corresponde à redação \\ final da dissertação devidamente corrigida \\ e defendida por Dairton Luiz Bassi Filho \\ e aprovada pela Comissão Julgadora.
}

São Paulo, março de 2008.

Banca Examinadora:

- Prof. Dr. Eduardo Colli (orientador) - IME-USP.

- Prof. Dr. Fabio Kon - IME-USP.

- Prof. Dr. Arlindo Flávio da Conceição - UNIFESP. 


\section{Agradecimentos}

Este trabalho aconteceu graças a colaboração de muitas mentes. Algumas influenciaram diretamente com sugestões e opiniões, outras proveram estímulos para reflexões, além daquelas que, mesmo involuntariamente, colaboraram com a convivência. Todas, de alguma forma ajudaram a lapidar este trabalho.

Agradeço à minha família e ao meu orientador, Prof. Dr. Eduardo Colli, pela confiança, incentivo e apoio durante todo o longo percurso deste mestrado. Especialmente, agradeço ao Prof. Dr. Fabio Kon, pela colaboração e exigência.

Agradeço aos companheiros da AgilCoop: Prof. Dr. João Eduardo Ferreira, Alexandre Freire, Paulo Cheque, Mariana Bravo e Hugo Corbucci que têm se dedicado a temas ágeis e, em especial, ao Prof. Dr. Alfredo Goldman, que sempre ofereceu ajuda e contribuições de ótima qualidade e, ao Danilo Sato, que colaborou com diversas sugestões e me acompanhou em várias missões ágeis.

Agradeço à Daniela dos Santos, pela ajuda na revisão. Agradeço à Kelly Braghetto, ao Igor Sucupira e a todos que contribuíram com a criação de um software importantíssimo para o IME, o Colméia. Agradeço ao pessoal da PR\&A, em particular ao Sérgio Malacrida, pela confiança depositada durante todo o projeto. Agradeço a equipe da ALESP, pelo excelente trabalho que realizamos juntos e, por fim, ao pessoal da Ikwa, que trabalha muito para fazer um sonho se tornar realidade.

\section{Obrigado, esta obra foi possível graças a vocês!}




\section{Resumo}

A crescente demanda por sistemas e a alta velocidade com que seus requisitos evoluem têm evidenciado que desenvolvimento de software exige flexibilidade, pois muitas decisões precisam ser tomadas durante o projeto. Além disso, as dificuldades para a produção de sistemas vão muito além das questões técnicas. Fatores estratégicos, comerciais e humanos são responsáveis por algumas das variáveis que contribuem para tornar o desenvolvimento de sistemas de software uma atividade altamente complexa.

Modelos tradicionais de desenvolvimento de software propõem processos prescritivos que não consideram toda essa complexidade. Por outro lado, Métodos Ágeis de desenvolvimento de software sugerem uma abordagem mais humanística com foco na entrega rápida e constante de software com valor de negócios. Porém, para conseguir isto, é preciso escolher um conjunto de práticas de desenvolvimento adequado às características do projeto e da equipe. Desta forma, a natureza única de cada projeto e a necessidade de alta qualidade e produtividade tornam importante a busca por práticas de desenvolvimento.

A partir de projetos que conduzimos usando métodos ágeis na academia e na indústria, identificamos e descrevemos 22 práticas para desenvolvimento de software que podem ser adotadas por equipes para aumentar o seu desempenho e/ou a qualidade do software.

Palavras-chave: Métodos Ágeis, Programação Extrema, Práticas, XP, Scrum, Crystal, Lean, Desenvolvimento de Software, Engenharia de Software, DSDM, ASD, EVO, FDD. 


\section{Abstract}

The growing demand for systems and the high speed with which their requirements evolve has shown that software development requires flexibility because many decisions need to be taken during the project. Also, the difficulties for the production of software systems go far beyond the technical issues. Strategic, commercial and human factors are responsible for some variables that contribute to make the software development a highly complex activity.

Traditional models of software development propose prescritive processes that do not consider all this complexity. On the other hand, Agile Methods of software development suggest an humanistic approach focused on fast and often business valuable software deliveries. But, in order to get it, one needs to choose an appropriated group of development practices accordingly to the project and team features. In this way, the individuality of each project and the need for better quality and productivity motivate the search for software development practices.

Based on projects that we conducted by using agile methods in academic and industry environments we identified and described 22 software development practices that can be used by teams to increase their performance and/or the software quality.

Keywords: Agile Methods, Extreme Programming, Practices, XP, Scrum, Crystal, Lean, Software Development, Software Engineering, DSDM, ASD, EVO, FDD. 


\section{Sumário}

Lista de Figuras $\quad$ v

Lista de Tabelas $\quad$ vii

1 Introdução 1

1.1 Escopo do Trabalho . . . . . . . . . . . . . . . . . . . . . . . 3

1.2 A Quem Pode Interessar . . . . . . . . . . . . . . . . . . . . . . . 5

1.3 Trabalhos Relacionados . . . . . . . . . . . . . . . . . . 5

1.4 Definições e Terminologia . . . . . . . . . . . . . . . . . . . . . 6

1.5 Organização do Trabalho . . . . . . . . . . . . . . . . . . 7

2 Métodos de Desenvolvimento de Software $\quad 9$

2.1 Métodos Tradicionais . . . . . . . . . . . . . . . . . . . . . . . . . 11

2.1 .1 Cascata . . . . . . . . . . . . . . . . . . . 12

2.1 .2 Prototipação . . . . . . . . . . . . . . . . . . 13

2.1 .3 Espiral . . . . . . . . . . . . . . . . . . . . 14

2.1.4 Rapid Application Development - RAD . . . . . . . . . . . . . . . 15

2.1.5 Rational Unified Process - RUP . . . . . . . . . . . . . . . . . 16

2.2 Processos Prescritivos e Processos Empíricos . . . . . . . . . . . . . . . 20

2.3 Métodos Ágeis . . . . . . . . . . . . . . . . . . . . . . . . . 22

2.3.1 Origem dos Métodos Ágeis . . . . . . . . . . . . . . . . . 22

2.3 .2 Características Comuns . . . . . . . . . . . . . . . . . . 24 
2.3.3 Evolutionary Project Management - EVO . . . . . . . . . . . . . . . 32

2.3.4 Dynamic Systems Development Method - DSDM . . . . . . . . . . . . . . 35

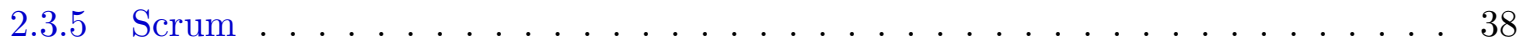

2.3.6 Feature Driven Development - FDD . . . . . . . . . . . . . . 42

2.3.7 Adaptative Software Development - ASD . . . . . . . . . . . . . . . . . 45

2.3.8 Programação eXtrema - XP . . . . . . . . . . . . . . 46

2.3.9 Família Crystal . . . . . . . . . . . . . . . . . 61

2.3.10 Lean Software Development . . . . . . . . . . . . . . . 71

3 Experiências com Desenvolvimento Ágil $\quad 77$

3.1 Na Universidade - IME-USP . . . . . . . . . . . . . . . . . . . . . 77

3.1 .1 Os Sistemas da USP . . . . . . . . . . . . . . . . . . . . 78

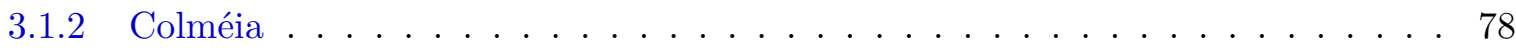

$3.1 .3 \mathrm{XP}$ e a Academia . . . . . . . . . . . . . . . . . 80

3.1 .4 Fase Incremental $\ldots \ldots \ldots$. . . . . . . . . . . . . . . . 83

3.1 .5 Fase de Maturação . . . . . . . . . . . . . . . . . . . . . . . . 86

3.1.6 Avaliação da Metodologia . . . . . . . . . . . . . . . . . . 88

3.2 No Setor Público - ALESP _ . . . . . . . . . . . . . . . . . . 89

3.2.1 Solução: Ajuda Especializada . . . . . . . . . . . . . . . . . . . 90

3.2 .2 Capacitação em Desenvolvimento . . . . . . . . . . . . . . . . . . 90

3.2 .3 Organização da Equipe . . . . . . . . . . . . . . . . . . 91

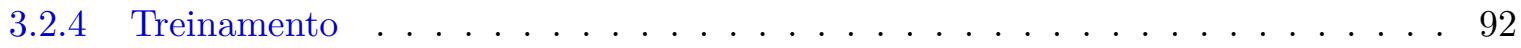

3.2.5 Implementação Assistida . . . . . . . . . . . . . . . . . . . . . . . 93

3.2.6 Resultados . . . . . . . . . . . . . . . . . . . . 95

$3.3 \mathrm{Na}$ Indústria $-\mathrm{PR} \& \mathrm{~A} \ldots \ldots \ldots \ldots \ldots$

3.3 .1 O Projeto e a Equipe . . . . . . . . . . . . . . . 97

3.3.2 Processo de Desenvolvimento . . . . . . . . . . . . . . . . . . 98

3.3 .3 Práticas Ágeis . . . . . . . . . . . . . . . . . . . . . . . 99 
3.3.4 Conclusão do Projeto . . . . . . . . . . . . . . . . . . . . 101

3.4 Uma Startup - Ikwa . . . . . . . . . . . . . . . . . . . . . . . . . . . 102

3.4 .1 Dificuldades de Startups . . . . . . . . . . . . . . . . . . 102

3.4 .2 Ambiente Colaborativo . . . . . . . . . . . . . . . . . 103

3.4 .3 Abordagem Ágil . . . . . . . . . . . . . . . . . . . . . . . . . . . . 104

3.5 Adoção de Práticas . . . . . . . . . . . . . . . . . . . . . . . . . 107

4 Práticas Ágeis $\quad 111$

4.1 Práticas Estratégicas . . . . . . . . . . . . . . . . . . . . 111

4.1 .1 Tripé de Conhecimentos . . . . . . . . . . . . . . . . . 112

4.1 .2 Acoplamento ao Cliente . . . . . . . . . . . . . . . . 114

4.1 .3 Nivelamento de Equipes . . . . . . . . . . . . . . . . 116

4.1 .4 Barreira de Entrada . . . . . . . . . . . . . . . . . . . 118

4.1 .5 Combatendo a Resistência Interna . . . . . . . . . . . . . . . . . . . . 119

4.1 .6 Combatendo a Resistência Externa . . . . . . . . . . . . . . . . . . . . 120

4.1 .7 Combatendo a Resistência Superior . . . . . . . . . . . . . . . . . . . . . 121

4.2 Práticas e Aspectos Motivacionais _ . . . . . . . . . . . . . . . . . 122

4.2.1 Responsabilidade Promove a Qualidade . . . . . . . . . . . . . . . 123

4.2 .2 Argumentos de Convencimento . . . . . . . . . . . . . . . . . . 124

4.2.3 Refatorações Aumentam a Motivação . . . . . . . . . . . . . . . . 126

4.2 .4 Hierarquia Fraca . . . . . . . . . . . . . . . . . . . . . 127

4.2.5 Desenvolvimento Mercenário _ . . . . . . . . . . . . . . . . . 128

4.2.6 Desafios com Prêmios ． . . . . . . . . . . . . . . . . . . . . 129

4.2 .7 Quebra de Rotina . . . . . . . . . . . . . . . . . . . 130

4.2.8 Motivação pelo Trabalho . . . . . . . . . . . . . . . . . . . . 131

4.3 Práticas de Desempenho . . . . . . . . . . . . . . . . . . . 132

4.3 .1 Solução Mínima . . . . . . . . . . . . . . . . . . 132

4.3 .2 Layout Exposto . . . . . . . . . . . . . . . . . . . 133 
4.3 .3 Posicionamento Otimizado f . . . . . . . . . . . . . . . 133

4.3.4 Controlando a Instabilidade . . . . . . . . . . . . . . . . . . . . 135

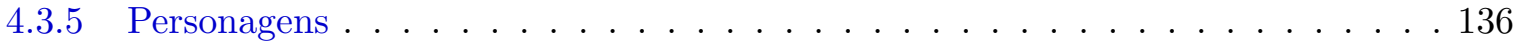

4.3 .6 Limite para Refatoração . . . . . . . . . . . . . . . . . . . . 138

4.3 .7 Integrando a Equipe . . . . . . . . . . . . . . . . . . . . . . 140

5 Considerações Finais $\quad 141$

5.1 Contribuições . . . . . . . . . . . . . . . . . . . . . . . . . . . . . . 142

5.2 Trabalhos Futuros . . . . . . . . . . . . . . . . . . . . . 143

Referências Bibliográficas $\quad 145$ 


\section{Lista de Figuras}

2.1 Histórico de publicações de metodologias de desenvolvimento de software. . . . . . . . 10

2.2 As fases do RUP e a distribuição do volume de atividades em cada uma delas [Rat]. . 19

2.3 Ciclo de melhoria contínua de Deming. . . . . . . . . . . . . . . . . . . . . . . . . . . 21

2.4 Exemplo de construção do gráfico de Valor e Risco. . . . . . . . . . . . . . . . . . . . . 29

2.5 Prioridade dos quadrantes com foco na eliminação de risco. . . . . . . . . . . . . . . 30

2.6 Prioridade dos quadrantes focada na entrega da primeira versão. . . . . . . . . . . . . . 31

2.7 Relação entre a satisfação do cliente e a presença de características básicas, de desempenho e excitantes. . . . . . . . . . . . . . . . . . . 32

2.8 Processo DSDM. . . . . . . . . . . . . . . . . . . . . . . . . . . 37

2.9 Ciclo de desenvolvimento do Scrum. . . . . . . . . . . . . . . . . . . . . . . . 41

2.10 Classificação de projetos pela criticalidade e número de envolvidos. . . . . . . . . . . . 63

2.11 Aplicação de metodologias Crystal conforme o número de envolvidos. . . . . . . . . . . 63

3.1 Uso tradicional das mesas e do espaço. . . . . . . . . . . . . . . . . . . . . . . . . 100

3.2 Ambiente de desenvolvimento potencializado para comunicação e compartilhamento de informações. . . . . . . . . . . . . . . . . . . . . . . . 100

3.3 Um das faces do quadro móvel com mural de tarefas e alguns rascunhos. . . . . . . . . 105

4.1 Pirâmide de Maslow com a hierarquia de necessidades que fortalecem a motivação. . . 122

4.2 Disposição física dos desenvolvedores conforme suas atividades. . . . . . . . . . . . . . 134

4.3 Exemplo de evolução da quantidade de refatorações pendentes com relação ao CFT e

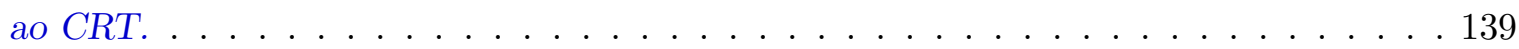




\section{Lista de Tabelas}

2.1 Objetivos das etapas do Ciclo de Deming. . . . . . . . . . . . . . . . . 21

2.2 Relação de dependência entre variáveis do projeto, analisadas duas a duas. . . . . . . . 27

2.3 Classificação das funcionalidades de acordo com as respostas dos usuários. . . . . . . . 33

3.1 Comparação de fatores da indústria e da academia que influenciam no desenvolvimento de software. . . . . . . . . . . . . . . . . . . . 82

3.2 Uso de práticas ágeis durante os projetos que estudamos. . . . . . . . . . . . . 109 


\section{Capítulo 1}

\section{Introdução}

Os avanços tecnológicos da academia e da indústria fizeram com que o software permeasse todas as atividades da sociedade contemporânea. Os principais centros urbanos tornaram-se completamente dependentes de computadores e de sistemas. Novos equipamentos eletrônicos são produzidos cada vez mais rápido e a crescente expansão desses dispositivos, em indústrias, no comércio e em domicílios, exige o desenvolvimento de sistemas cada vez mais especializados e avançados. Esta realidade implica diretamente o aumento da demanda por softwares e implica indiretamente a busca por maneiras mais apropriadas de desenvolvê-los.

Neste cenário, o mercado de software tem se tornado mais competitivo, fazendo com que as necessidades se alterem e evoluam com mais velocidade, exigindo que a Engenharia de Software desenvolva a capacidade de se adaptar a mudanças. Historicamente, o contato com requisitos instáveis e a falta de envolvimento das pessoas que retinham o conhecimento fez com que diversos modelos de desenvolvimento de software se mostrassem inapropriados. No CHAOS Report de 1994 [Sta94], 365 empresas colaboraram com a avaliação de 3682 projetos. $83,2 \%$ foram cancelados ou entregues excedendo o orçamento ou o prazo estimados. Dentre esses projetos, o custo foi em média $89 \%$ acima do previsto e o atraso médio foi de $122 \%$ além do planejado. Os participantes também declararam as principais razões para esses resultados e apenas seis fatores representaram juntos a 60,35\% das possíveis causas: requisitos incompletos, falta de envolvimento de usuários, mudanças de requisitos e especificações, falta de apoio da equipe de negócios, falta de recursos e expectativas não-realistas [Sta94].

Versões mais recentes do relatório mostram uma tendência de melhora na qualidade dos projetos, porém a situação ainda requer atenção pois os dados de 2004 indicam que só $29 \%$ dos projetos são finalizados com sucesso e o percentual de projetos que excedem os custos ou o prazo, mantém-se tão 
elevado quanto antes. Além disso, Shull et al. apontam que mais de $50 \%$ dos sistemas entram em produção com defeitos que afetam a execução $\left[\mathrm{SBB}^{+} 02\right]$.

Esses dados apenas evidenciaram a realidade da indústria de software. Mesmo antes dessas publicações, o desconforto causado por vários resultados ruins estimulou diversos esforços no ramo da Engenharia de Software para encontrar maneiras mais eficientes de desenvolver sistemas complexos. Alguns processos tentaram mapear com abrangência as etapas do desenvolvimento, resultando em modelos como: Unified Process (UP) [JBR99], Cleanroom Software Engineering [MDL87] e $R a-$ pid Application Development (RAD) [KH93] que posicionaram-se como alternativas baseadas em um processo pré-definido. Somados ainda a modelos de certificação que foram criados para validar a aplicação dos processos, o Capability Maturity Model Integration (CMMi) [CKS03], ISO 9000-3 [KJ95], Six Sigma [Har98] e o modelo de Melhoria de Processos de Software Brasileiro (MPS.BR) [WRA ${ }^{+}$04] são alguns exemplos. Para os profissionais, o Project Management Institute (PMI) regula a certificação sobre o conhecimento das práticas de gerenciamento do Project Management Body of Knowledge (PMBOK) [Ins04]. Porém, apesar das boas intenções dessas iniciativas, todas abordam o desenvolvimento de software como um processo que pode ser repetido mecanicamente, tentando enquadrá-lo em uma linha de produção.

Apesar do software ter se tornado um bem de consumo facilmente comprável pela Internet, no shopping center, ou mesmo, no supermercado, ele possui características diferentes da maioria dos bens de consumo produzidos industrialmente em linhas de produção, como carros, telefones ou parafusos. Primeiro, porque carros ou pequenos parafusos dependem essencialmente de matéria-prima e das ferramentas certas para serem produzidos. Segundo, porque depois de criada uma unidade, é possível determinar a quantidade de matéria-prima necessária para produzir um certo número de carros, a fim de atender a demanda de clientes. E terceiro, porque a produção de bens de consumo que seguem linhas de montagem podem ser feitas inteiramente por máquinas sem a intervenção humana no processo. Com software, não existe matéria-prima palpável e a grande dificuldade está em criálo, não em replicá-lo. Depois de pronto, pode-se reproduzir quantos exemplares (cópias) forem necessários por um custo que tende a zero sem que o número de usuários finais influencie o valor investido para a sua criação. Além disso, o desenvolvimento de software usa outros softwares como ferramentas e conta, indispensavelmente, com a participação de profissionais qualificados. De forma que, o conhecimento e as habilidades dos envolvidos são, de fato, sua principal "matéria-prima".

$\mathrm{Na}$ metade da década de 90, algumas iniciativas deram origem a metodologias que foram na contra-mão do grande fluxo da indústria de software. Estas concentraram-se nos fatores humanos e 
em entregar valor ao cliente e não na burocracia dos processos. Esses métodos foram inicialmente chamados de leves. Depois de diversos resultados positivos, seus líderes se reuniram em 2001 para discutir suas técnicas e publicaram um manifesto que reuniu os valores essenciais de suas metodologias $\left[\mathrm{BBvB}^{+} 01\right]$. A partir de então, essas metodologias leves passaram a ser chamadas de Métodos Ágeis, dos quais seus principais representantes são: Programação Extrema (XP), Scrum, DSDM, Lean e Crystal.

Atualmente, tão rápido quanto a tecnologia evolui, a pesquisa e a possibilidade de acesso a informações precisas e confiáveis faz com que as necessidades mudem e os sistemas de software tornem-se obsoletos em menos tempo. Como conseqüência, a demanda por software cresce e os prazos diminuem. Essa realidade aumenta a instabilidade e torna o desenvolvimento de um software uma operação mais sensível à influência de elementos externos à equipe técnica. Questões comerciais, mudanças de prioridade, mudanças de escopo e incertezas no planejamento são alguns dos fatores que contribuem para tornar o desenvolvimento de um software uma tarefa complexa. Ademais, o inerente envolvimento de seres humanos não pode ser ignorado, pois o sucesso da produção de um software depende também da motivação, do comprometimento e de uma comunicação eficaz entre os envolvidos. Todas estas variáveis acrescentam um grau de imprecisão que muitas vezes é ignorado. Além disso, elas corroboram para elevar a instabilidade do processo e tornar o desenvolvimento de cada software uma atividade altamente específica, de tal forma que o uso de um processo comum e preestabelecido se faz inadequado.

As metodologias ágeis têm ciência dessa complexidade e admitem que também não conseguem prever todas as possibilidades, por isso oferecem liberdade para adaptações conforme o contexto de cada projeto. Em vista disto, identificar técnicas para desenvolver software que considerem também

os fatores associados à participação humana torna-se uma área de estudos relevante para a academia e, principalmente, para a indústria. Considerando ainda que o principal foco dos métodos ágeis são equipes pequenas e que pequenas empresas representam $85 \%$ das empresas da maior indústria mundial de software, a americana [RvW07], a importância de pesquisas por novas metodologias e práticas ágeis cresce ainda mais.

\subsection{Escopo do Trabalho}

Neste trabalho, estudamos os principais modelos de desenvolvimento de software usados na indústria com enfoque especial nas metodologias ágeis. A partir dessa investigação, focamos em identificar práticas que possam ser combinadas a essas metodologias para tornar a equipe de desenvolvimento 
mais eficiente e produtiva. Experimentamos variações nas metodologias ágeis e novas práticas em quatro projetos realizados na universidade, com softwares de código aberto e, na indústria, em projetos com fins comerciais.

Dentro da universidade, utilizamos os recursos disponíveis para produzir sistemas que atendessem as necessidades dela própria e da sociedade. Aliamos a capacidade técnica dos professores e alunos do IME-USP com um modelo de desenvolvimento baseado em métodos ágeis para que, ao mesmo tempo em que aprendiam, os alunos pudessem contribuir para a produção de aplicações que mais tarde seriam usadas por centenas ou milhares de usuários.

A escolha dos sistemas a serem desenvolvidos foi feita de acordo com as necessidades de grupos de usuários de dentro da universidade. O mais urgente foi um sistema completo para gerenciamento de bibliotecas. Este foi o projeto onde iniciamos nossa pesquisa. Devido às grandes dimensões do projeto, nos propusemos a concluir apenas um dos módulos, assim pudemos participar de outros projetos e aumentar a variedade de experiências que compuseram este trabalho. O módulo que trabalhamos encontra-se em produção na biblioteca do IME-USP e, além deste, outros módulos estão parcialmente finalizados.

$\mathrm{Na}$ indústria, nossos objetos de estudo foram três projetos em segmentos diferentes nos quais introduzimos metodologias ágeis. O primeiro foi o desenvolvimento do sistema de controle de recursos humanos da Assembléia Legislativa do Estado de São Paulo (ALESP). O segundo, realizado na PR\&A, foi um software para análise de ativos do mercado financeiro. O terceiro, por fim, foi a estruturação da área de tecnologia e o desenvolvimento de todos os softwares da Ikwa, uma jovem empresa do segmento de internet que busca estabilidade financeira.

Nossa atuação aconteceu em vários níveis dentro de cada projeto. No nível estratégico, contribuiu para decisões de posicionamento de marca e entrada no mercado. No nível tático, formou as equipes de desenvolvimento e auxiliou clientes e equipes a escolherem as tecnologias adequadas. No nível gerencial, com a definição de processos leves para equipes pequenas, o tutoramento dos envolvidos, a liderança dos projetos e a colaboração com clientes para a definição do software. No nível da implementação, contribuiu com participação ativa nas atividades de análise, design, modelagem, programação, testes, implantação e manutenção.

Com a participação nesses quatro projetos, tivemos a oportunidade de usar diferentes combinações de metodologias e práticas de desenvolvimento ágil com o objetivo de identificar quais se mostravam mais adequadas a cada contexto. A partir dessas experimentações e da convivência diária com as 
equipes de desenvolvimento, pudemos observar similaridades e tirar conclusões que compilamos em um conjunto de práticas e percepções relevantes às equipes de desenvolvimento de software. Dentre essas conclusões, várias levam em conta fatores atrelados ao lado humano da produção de software, pois acreditamos que esses aspectos possuem alta relevância nas atividades em equipe. Desta forma, as análises e conclusões deste trabalho apresentam resultados essencialmente qualitativos.

\subsection{A Quem Pode Interessar}

Esta dissertação contém informações que atendem tanto ao interesse acadêmico quanto ao da indústria. Nossos relatos reúnem evidências de benefícios do uso de métodos ágeis que podem ser usados pela academia como mais uma fonte de resultados qualitativos e, por empresas, como base para a implantação de métodos ágeis. Leitores iniciantes em desenvolvimento ágil, estudantes e curiosos poderão se beneficiar da revisão sobre metodologias ágeis de desenvolvimento de software, onde descrevemos tais métodos oferecendo uma ampla visão sobre o tema, com referências para estudos mais aprofundados sobre cada tópico. Leitores experientes terão provavelmente mais interesse pelos casos de estudo e pelas práticas que propomos.

Equipes, não exclusivamente adeptas da filosofia ágil, mas interessadas em aprimorar seu modo de trabalho, encontrarão diversas técnicas para lidar com as dificuldades do desenvolvimento de sistemas, tais como: priorização de funcionalidades, negociação com clientes, identificação de funcionalidades e estimação de tarefas. Além disso, encontrarão uma grande variedade de práticas que podem ser facilmente utilizadas pela equipe ou, incorporadas como base de conhecimento para a criação de suas próprias práticas.

\subsection{Trabalhos Relacionados}

A bibliografia que serviu de base para identificar as características das metodologias ágeis abordadas neste trabalho foi: XP [BA04, Bec99, JAH00], Scrum [SB02, Sch04], Crystal [Coc06, Coc04, Coc98], FDD [CdLL99,PF02], Lean [Ohn88, PP03,PP06,Dem86], EVO [Gil76, Gil88], DSDM [SS03] e ASD [Hig04]. Para os interessados em RUP, as principais referências são [JBR99, KK03, Kru03]. O métodos tradicionais podem ser consultados em [Pre04] e [Som06].

Alguns estudos analisam especificamente os impactos e benefícios da programação em pares [CW01, WKCJ00, CS06, Nos98, WK02, SBB ${ }^{+}$02]. Além deste, outros temas também relacionados com este trabalho são: planejamento ágil [Coh06,BF01], desenvolvimento dirigido por testes [Bec03] e produ- 
tividade de equipes de desenvolvimento de software [DL99, DeM01].

$\mathrm{Na}$ academia, métodos ágeis é um tema que desperta cada vez mais o interesse de pesquisadores e estudantes. Diversos relatos, descrevem o uso de métodos ágeis. Dogs e Klimmer coletaram dados sobre as características do desenvolvimento em empresas e fizeram algumas recomendações para melhoria baseados em métodos ágeis [DK04]. Fransson analisou quantitativamente os impactos do uso de métodos ágeis na indústria sueca [FaK05]. Kalermo e Rissanen estudaram a evolução do desenvolvimento de software e proveram uma análise detalhada dos 12 princípios do Manifesto Ágil. Eles também apresentam um caso de estudo e apontam as adaptações que fizeram para tornar a abordagem ágil mais adequada ao projeto [KR02].

No Brasil, algumas dissertações também foram publicadas com temas relacionados. Teles apresentou conclusões sobre o uso de XP [Tel05], Freire descreveu experiências com ensino de XP [Fre07] e Sato apresentou formas eficazes de coleta e análise de métricas em projetos que utilizam desenvolvimento ágil [Sat07].

Além desses trabalhos, inúmeros artigos relatam casos de uso de metodologias ágeis na academia e na indústria [Coc00, $\mathrm{ABB}^{+}$98, $\mathrm{SR} 07, \mathrm{GBL}^{+}$04,SVBP07, JZ03,PP05, Dan05, KA96, $\mathrm{SBB}^{+}$06, ZMMW01, FKT05] com resultados que contribuem para fortalecer as evidências de eficácia dos metodos ágeis. Os relatos incluem descrições de como as metodologias foram aplicadas e adaptadas para cada contexto, utilizando também novas práticas ou variações das práticas propostas originalmente por essas metodologias.

\subsection{Definições e Terminologia}

Não é o objetivo deste trabalho chegar a conclusões sobre a definição de termos. Portanto, usamos os termos metodologia, método e modelo de desenvolvimento como sinônimos para representar formas de trabalho encontradas na literatura ou usadas por equipes de desenvolvimento de software.

Nosso foco recai sobre as técnicas e atividades realizadas durante a produção de um software. Portanto, cada atividade realizada regularmente por um ou mais desenvolvedores, nós chamamos de prática. Projeto é um esforço temporário com o objetivo de criar ou melhorar um software e, para cada projeto, usamos software e sistema como sinônimos para denotar o produto que a equipe está implementando. 


\subsection{Organização do Trabalho}

O trabalho segue a seguinte organização: no Capítulo 2, descrevemos os modelos de desenvolvimento de software mais usados na indústria, com enfoque em métodos ágeis. No Capítulo 3, relatamos os projetos de desenvolvimento de software onde aplicamos metodologias ágeis. No Capítulo 4, com base em nossas experiências, apresentamos nossas percepções no formato de práticas que podem ser utilizadas por outras equipes de desenvolvimento. Finalmente, o Capítulo 5 reúne nossas conclusões e as principais linhas de pesquisa para trabalhos futuros. 


\section{Capítulo 2}

\section{Métodos de Desenvolvimento de Software}

Neste capítulo, descrevemos os principais modelos de desenvolvimento de software utilizados para produção de sistemas de software na indústria. Nosso objetivo é oferecer uma visão ampla sobre o tema, sem discutir os detalhes mínimos de cada método. Leitores interessados em se aprofundar poderão seguir as referências que sugerimos no decorrer do texto.

Começamos com uma rápida contextualização sobre modelos tradicionais, por possuírem uma grande importância na história da Engenharia de Software e por serem amplamente utilizados pela indústria de software. Em seguida, dissertamos brevemente sobre processos prescritivos e empíricos. Depois, abordamos com mais profundidade os modelos ágeis; um grupo de metodologias que têm ganhado considerável destaque na indústria e que fornece a principal base de idéias para o nosso trabalho. Na Figura 2.1, apresentamos o histórico de surgimento dos principais métodos de desenvolvimento de software usando como critério o ano de sua publicação. 


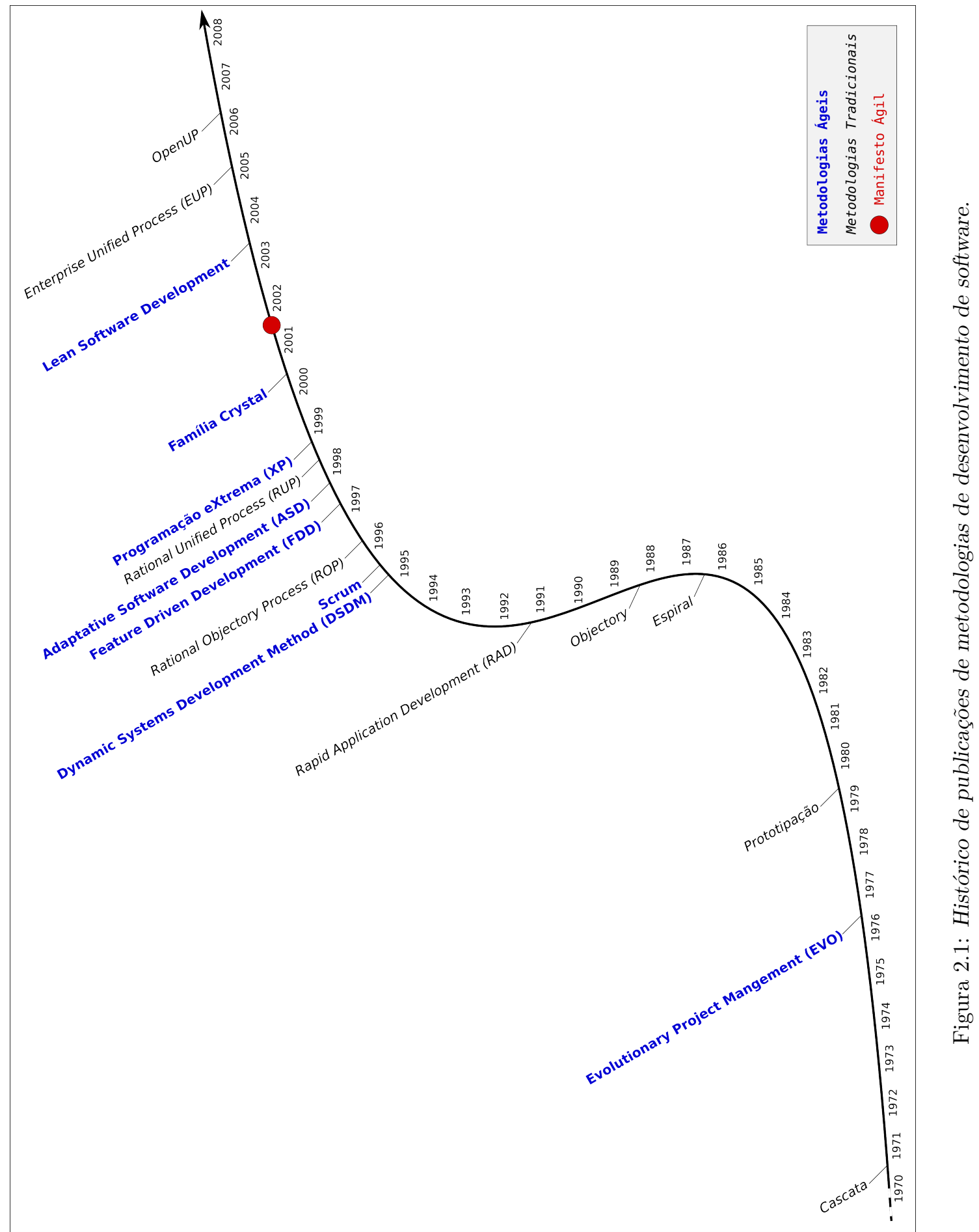




\subsection{Métodos Tradicionais}

Desde o final da década de 60, técnicas de engenharia passaram a ser usadas para o desenvolvimento de sistemas de software com o objetivo de definir processos que pudessem ser descritos e depois replicados. Essas abordagens segmentam a criação do software em fases apoiadas por processos, pelo uso de ferramentas e por uma documentação detalhada de tudo que é produzido.

Como parte do processo, a equipe precisa produzir diversos tipos de itens intermediários até chegar no produto final. Alguns exemplos são: diagramas UML, glossários, cenários de uso, especificações, modelagens, solicitações, planos de trabalho, formulários, componentes, testes, relatórios, análises, manuais, dados de carga, entre outros. Estes elementos são chamados genericamente de artefatos. Para cada fase da produção do software, alguns artefatos são criados ou atualizados e um conjunto de ferramentas deve ser usado para armazenar dados que podem ser empregados em análises ou servir como uma parte da documentação. Os documentos criados em cada etapa descrevem os detalhes do trabalho realizado até aquele momento, de forma que a próxima fase possa usá-los como base para continuar a produção do software. Esta, por sua vez, atualiza e produz novos documentos que serão utilizados pela etapa seguinte. Neste contexto, os documentos atuam como elos entre as fases do desenvolvimento e, entre os seus participantes, exercendo duas funções específicas: servem como registros históricos das decisões do projeto e também como manuais que explicam o código e o funcionamento do sistema.

A documentação influi fortemente na comunicação da equipe de desenvolvimento e em suas interações com pessoas de fora dela, tais como clientes e usuários. Inicialmente, os requisitos são definidos formalmente através de documentos para que os arquitetos, programadores e testadores os usem como base para criar o sistema. Com uma documentação vasta e altamente detalhada é possível que inúmeras pessoas trabalhem em um projeto sem compartilhar o mesmo espaço físico ou estarem presentes no mesmo horário, podendo chegar ao ponto em que essas pessoas não precisem se falar pessoalmente ou sequer se conhecerem.

Apesar da comunicação ser fortemente afetada pelos documentos, na prática eles dificilmente substituem a comunicação verbal e as interações entre pessoas. O uso de documentos colabora para a criação de dois níveis de interação: um informal, onde estão as relações interpessoais, compreendidas por bate-papos, conversas ao telefone e pequenas discussões; e outro oficial, que é feito através do conjunto de artefatos produzido para o projeto. Em geral, o primeiro serve como um "rascunho" para o segundo, pois, após as interações acontecerem informalmente, o resultado relevante vai para 
o papel ou para um sistema $\mathrm{CASE}^{1}$ e passa a fazer parte da comunicação oficial do projeto.

Além dos documentos que auxiliam no fluxo do processo de desenvolvimento, existe também toda a documentação para o código. Cada elemento do software, como por exemplo, classes, componentes ou módulos, deve possuir a documentação que explica o seu funcionamento e utilização. Assim, qualquer pessoa pode compreendê-lo, usá-lo ou aprimorá-lo. A documentação sobre o código também tem o papel de compartilhar o conhecimento do criador, reduzindo o risco de centralização de informações e facilitando a participação de outros profissionais no projeto.

\subsubsection{Cascata}

O modelo Cascata foi o primeiro paradigma largamente utilizado dentro da engenharia de software. Em 1970, quando a indústria de software acabara de assumir sua ineficiência para a construção de sistemas, Royce sugeriu uma abordagem pragmática e linear que a indústria usou indiscriminadamente para a construção de todos os tipos de sistemas [Roy70].

Neste modelo, o software final é obtido através da execução de etapas sistematicamente definidas. Segundo Pressman, o processo segue linearmente as etapas de: engenharia do sistema, análise de requisitos, projeto, geração de código, testes e manutenção [Pre04]. Em cada uma dessas fases, um conjunto preestabelecido de atividades é realizado de forma que os artefatos produzidos em cada etapa sirvam de entrada para a etapa seguinte. Cada fase tem as seguintes características:

- Engenharia do Sistema - Constitui a coleta e análise de requisitos de alto nível e de equipamentos para definir os requisitos tecnológicos e possíveis limitações.

- Análise de Requisitos - Consiste na identificação das funcionalidades desejadas para o software. Nesta fase é adquirido conhecimento detalhado sobre o domínio de negócios que o sistema se propõe a tratar. Os tipos de interação, as necessidades de interface e todos os fatores que determinam a maneira como usuários e outros sistemas utilizarão o novo software devem ser identificados, documentados e revistos pelo cliente.

- Projeto - Define as características da implementação. São propostas soluções para arquitetura, modelagem, estruturas de dados e as interfaces entre os elementos do sistema. Essas soluções devem cobrir todos os requisitos identificados nas fases anteriores, assim como atender às res-

\footnotetext{
${ }^{1}$ Computer-Aided Software Engineering.
} 
trições e aos níveis mínimos de qualidade preestabelecidos. O resultado é uma especificação detalhada do código, que define como cada parte do sistema deve ser implementada.

- Geração de Código - Implementação conforme descrito na especificação do projeto.

- Testes - Cada elemento e componente do sistema é validado de acordo com sua especificação. Os testes podem ser de dois tipos: caixa preta, baseados apenas nas interfaces oferecidas pelo sistema e, caixa branca, que testam o software conhecendo a sua implementação.

- Manutenção - Caracteriza-se por definir a criação de uma nova versão para o software, que irá substituir a atual. Com uma versão em produção, o software volta para alguma das fases anteriores para a inclusão de novas funcionalidades ou para ajustes ou melhorias.

\subsubsection{Prototipação}

Um dos grandes problemas no desenvolvimento de sistemas é a ineficácia da coleta dos requisitos [Lar04]. Todo o processo de construção do software depende de uma identificação eficiente das necessidades e do conhecimento criado no início do projeto. Nesta fase são definidos os objetivos e as características do sistema. Análises erradas ou incompletas podem conduzir o desenvolvimento por um caminho com metas diferentes das intencionadas pelos clientes e usuários. Tal situação eleva radicalmente o custo de correções $\left[\mathrm{SBB}^{+} 02\right]$.

Para conseguir melhores resultados nos casos em que as fases de análise não são capazes de identificar todos os requisitos, o modelo de Prototipação sugere a construção de um projeto-piloto para auxiliar a identificação dos requisitos do sistema principal [BW79, Can81]. Neste modelo, após uma fase inicial de análise e coleta de requisitos, a equipe de desenvolvimento parte para a construção de um protótipo do projeto principal com o objetivo de tornar as discussões em torno do suposto produto mais palpáveis. Com base no protótipo, o cliente pode refinar suas idéias e sugerir mudanças, até possuir uma visão consistente o suficiente para delinear as características do produto final.

O protótipo pode ser construído com vários propósitos, de acordo com o grau e a origem das incertezas dos envolvidos no projeto. Nos casos em que o objetivo do protótipo é auxiliar clientes e usuários a delinearem seus desejos através de uma interface gráfica, o protótipo pode ser produzido mais rápido em uma linguagem de programação menos robusta, mas mais produtiva do que a que será usada no projeto principal. Mais uma motivação para criar um protótipo é a avaliação de novas tecnologias ou de tecnologias pouco familiares à equipe de desenvolvimento. Esta poderá oferecer 
estimativas mais apuradas sobre as dificuldades da construção do software. Protótipos também são úteis para a avaliação do desempenho de algoritmos que podem causar impacto na usabilidade do sistema. Casos em que o software inerentemente precisa garantir um determinado tempo de resposta podem justificar a realização de um protótipo para a medição da viabilidade do projeto [Pre04].

O ponto fraco desta abordagem é a falsa impressão que os clientes adquirem ao verem o protótipo. É comum pensarem que o produto está quase finalizado quando na verdade ele sequer foi iniciado. Esta ilusão é bastante comum para pessoas sem conhecimento técnico, principalmente quando o protótipo possui interface gráfica. Em função disso, a equipe de desenvolvimento pode receber pressão para entregar o produto mais rápido e ser obrigada a suprimir algumas etapas do processo.

A proposta de continuar o desenvolvimento a partir do protótipo é pouco aconselhável porque o protótipo foi geralmente elaborado rapidamente com o objetivo de apresentar algo com aparência similar ao sistema final ou comportamento simplificado [Pre04]. Portanto, esta solução não considera todos os requisitos na especificação da arquitetura e, obviamente, não considera os requisitos descobertos a partir das discussões desencadeadas pelo protótipo.

\subsubsection{Espiral}

O modelo Espiral, proposto por Berry Boehm em 1986 [Boe86], apresenta duas grandes inovações em relação aos modelos anteriores: 1) a introdução do modelo iterativo, no qual as etapas do desenvolvimento são realizadas várias vezes no formato de ciclos e, 2) a inclusão de uma etapa de análise de riscos, onde os envolvidos no projeto podem avaliar e tomar decisões conforme as dificuldades que surgem durante o desenvolvimento.

As abordagens cascata e de prototipação estão presentes como uma das etapas do ciclo de desenvolvimento do modelo espiral. Cada iteração é formada por quatro etapas: Planejamento, Análise de Riscos, Engenharia e Avaliação do Cliente. A cada iteração, o produto evolui e se aproxima do que será a versão que entrará em produção.

- Panejamento - Inicialmente são coletados os requisitos principais para realizar um planejamento de alto nível e determinar objetivos e restrições. Depois do primeiro ciclo, a avaliação do cliente também é considerada durante o planejamento.

- Análise de riscos - Os riscos associados ao projeto são identificados através do levantamento das incertezas associadas aos requisitos. A partir da análise dos principais riscos, o objetivo é 
encontrar soluções ou alternativas que reduzam as incertezas identificadas. Por fim, é tomada a decisão de continuar com o projeto ou pará-lo.

- Engenharia - O produto definido na etapa de planejamento é de fato construído. Contudo, o objetivo não é produzir o sistema todo de uma só vez, mas sim por partes, através de várias iterações do ciclo de desenvolvimento. Cada execução da etapa de engenharia pode usar o modelo cascata ou a prototipação.

- Avaliação do cliente - O cliente analisa o trabalho realizado na etapa de engenharia de acordo com os objetivos definidos no planejamento e acrescenta comentários, sugestões, modificações e críticas que serão considerados na próxima iteração.

A análise de riscos permite que periodicamente os envolvidos no projeto parem para avaliar o andamento, permitindo focar a atenção nos impedimentos do momento. Com essa abordagem o desenvolvimento caminha para um formato em que os envolvidos tornam-se obrigados a repensar seus objetivos e a viabilidade do projeto durante a execução.

Muitas vezes, o software produzido não corresponde aos pedidos do cliente ou contém muitos erros devido à falta de compreensão das regras de negócio pela equipe de desenvolvimento, quer pela quantidade de regras, quer pela sua complexidade. O caráter evolutivo deste modelo permite que a equipe técnica tenha mais tempo para dominar os novos conceitos, pois eles são introduzidos gradativamente durante os ciclos de desenvolvimento. Como conseqüência, a visão e o planejamento do projeto se tornam reduzidas, porém mais realistas com a coleta de requisitos e as análises fragmentadas no decorrer do processo.

A grande desvantagem do espiral é a dificuldade para determinar o número de ciclos de desenvolvimento necessários para conclusão do projeto e, portanto, é difícil dizer quando será o final do projeto. No entanto, modelos não-iterativos também não conseguem determinar com precisão a duração de projetos.

\subsubsection{Rapid Application Development - RAD}

James Martin criou o RAD [Mar91] no início da década de 90 com a proposta de produzir aplicações com um único ciclo de desenvolvimento, de no máximo três meses. Apesar do nome e de usar um ciclo de desenvolvimento relativamente curto, RAD não é um método ágil. Ele é especialmente recomendado para aplicações que possam ser modularizadas, com escopo claro e bem 
definido [Mar91]. Sua abordagem se baseia em quebrar o software em módulos para que várias equipes trabalhem ao mesmo tempo. Cada equipe trabalha em um dos módulos, usando o modelo cascata com as seguintes etapas: modelagem de negócios, modelagem de dados, modelagem do processo, geração da aplicação, testes e correções [KH93]. No final, os módulos são integrados.

As duas principais vantagens do RAD são: a proposta de concluir o projeto em um período preestabelecido e relativamente curto (90 dias) e o estímulo à produção de componentes modularizados e reutilizáveis. Por outro lado, há alguns pontos negativos: requer mais pessoal e equipamentos para equipes que trabalham simultaneamente, não comporta mudanças de requisitos e não é recomendado quando os riscos técnicos são altos.

\subsubsection{Rational Unified Process - RUP}

O RUP é a implementação da Rational Corporation para o Processo Unificado (UP) de desenvolvimento de software [JBR99]. No fim da década de 80, a empresa de Ivar Jacobson, a Objectory $\mathrm{AB}$, definiu um processo para o desenvolvimento de software baseado em documentos UML, o Objectory v1.0 [JCJO92]. Mais tarde, em 1995, a Rational adquiriu a Objectory AB e integrou seus produtos para, no ano seguinte, criar o Rational Objectory Process (ROP) 4.0, introduzindo conceitos iterativos. Finalmente, em 1998, o Rational Unified Process 5.0 foi lançado [JBR99] e, ao longo dos anos seguintes, expandiu a gama de elementos em seu arcabouço. Atualmente, as várias dezenas de práticas, artefatos e papéis que dispõe, permitem que, cada vez mais, o RUP se apresente mais flexível aos diferentes contextos da indústria de software [Kru03] e, ao mesmo tempo, possibilitam que outras implementações do Processo Unificado, como o OpenUP [KM06] e o Enterprise Unified Process (EUP) [ANV05], ofereçam processos com pesos variados.

Durante muitos anos, o UP/RUP teve seu uso canalizado para o desenvolvimento de grandes aplicações, o que o deixou com um estigma de processo pesado. Porém, com a crescente disseminação das metodologias ágeis, a própria Rational ${ }^{2}$ tem se empenhado para reforçar a imagem de processo flexível e adaptável [Eva03]. Na definição do processo há flexibilidade para a implantação e é sugerido que, apesar da vastidão de elementos no arcabouço, um número reduzido de artefatos seja selecionado para cada caso de desenvolvimento ${ }^{3}$ [KK03]. Reforçando esta tendência, Ivar Jacobson publicou

\footnotetext{
${ }^{2}$ No início de 2003, a IBM adquiriu a Rational Corporation, no entanto, preservou seu nome no processo e nas ferramentas.

${ }^{3}$ Conjunto de artefatos escolhidos especificamente para cada aplicação do UP.
} 
um artigo intitulado "Enough of Processes - Lets do Practices" [JNS07], colocando o foco na produção do software, não no processo. Além disso, as premissas listadas por Kruchten mostram uma mescla entre características ágeis e tradicionais [Kru03]:

1. Ataque os riscos rápido e sempre, senão eles irão atacar você.

2. Entregue valor rápido e constantemente ao seu cliente.

3. Foque em entregar software funcionando nas primeiras iterações.

4. Descubra e acomode as mudanças no início do projeto.

5. Defina a arquitetura cedo.

6. Prefira arquiteturas orientadas a componentes e reutilize os componentes.

7. Trabalhe como uma única equipe.

8. Qualidade é um estilo de vida, não um privilégio.

Os valores ágeis (Subseções 2.3.1 e 2.3.2) são percebidos nas premissas de número 1, 2, 3, 6 e 7 . Em paralelo, conceitos característicos de metodologias tradicionais aparecem claramente nas premissas 4 e 5. A $8^{\text {a }}$ premissa, que diz respeito à qualidade, decidimos não atribuir como característica de nenhuma metodologia, uma vez que todas visam à produção de software com alta qualidade.

\section{Artefatos}

Uma das capacidades do Processo Unificado é a possibilidade de acomodar seu grau de formalismo e documentação para uso em equipes de diversos tamanhos. Desde equipes com menos de uma dúzia de participantes, até grandes projetos com várias centenas de colaboradores. Ao todo, o arcabouço conta com diversas dezenas de tipos de artefatos que podem ser criados durante o projeto [Kru03]. Fica a critério da empresa e do projeto a escolha de quais deles estarão presentes em cada caso de desenvolvimento. No entanto, a Visão e a Lista de Risco são o mínimo que o processo precisa possuir para ser considerado Processo Unificado. Esta liberdade para escolha sobre uma grande gama de artefatos permite que a implementação do Processo Unificado seja tão leve ou pesada quanto se queira [KK03]. No entanto, a maior dificuldade é justamente conseguir a percepção do conjunto ideal de práticas e documentos. 
A grande diversidade do arcabouço oferece a possibilidade de flexibilizar o processo com a substituição de alguns artefatos por outros de caráter menos formal, como cartazes na parede, fotos, diagramas na lousa ou vídeos explicativos, contanto que recebam nomes de acordo com um vocabulário comum para não prejudicar a comunicação e permitir que empresas com centenas de desenvolvedores possam reutilizar artefatos e integrar novos participantes com mais facilidade.

\section{Fases}

O Processo Unificado passa por quatro fases: Concepção, Elaboração, Construção e Transição. Cada uma é composta por iterações idealmente curtas, de duas a seis semanas. O avanço para a próxima fase acontece quando os objetivos da fase anterior são alcançados. Tais objetivos são apresentados na listagem abaixo. Contudo, o modo de alcançá-los não é estritamente determinado pela metodologia. O projeto e as condições de trabalho da empresa devem ser levados em consideração para a escolha das atividades e artefatos criados para atingir as metas. A Figura 2.2 mostra a distribuição de atividades ao longo das fases.

- Concepção - Dura geralmente poucos dias, o suficiente para estabelecer uma visão de alto nível dos objetivos, do escopo e das prioridades. Visa a coletar os $10 \%$ de requisitos mais relevantes, identificar os principais riscos e elaborar uma estimativa de esforços. Isso é feito através de oficinas de requisitos [Kru03], com histórias e cenários de uso, de prototipação, de rascunhos de interface e da identificação de regras, restrições e requisitos não-funcionais.

- Elaboração - A compreensão dos requisitos se estende em quantidade e em profundidade. O núcleo da arquitetura e as partes mais críticas são desenvolvidos e testados de forma que os principais riscos sejam minimizados e seja possível obter uma estimativa razoável de duração e esforço. Essas metas são alcançadas através de iterações curtas contendo oficinas de requisitos, modelagem, programação e testes.

- Construção - Com base em uma estrutura estável criada nas etapas anteriores, a implementação do sistema é realizada, por isso esta fase tende a ser a mais longa do processo. Uma versão alpha com documentação é produzida usando iterações curtas com pouca modelagem e muita programação, testes e avaliações dos clientes.

- Transição - O sistema fica pronto para entrar em produção. Uma versão beta é produzida e avaliada. Com base no feedback obtido, alguma programação e ajustes são feitos para chegar à 
versão que entrará em produção acompanhada da documentação completa.

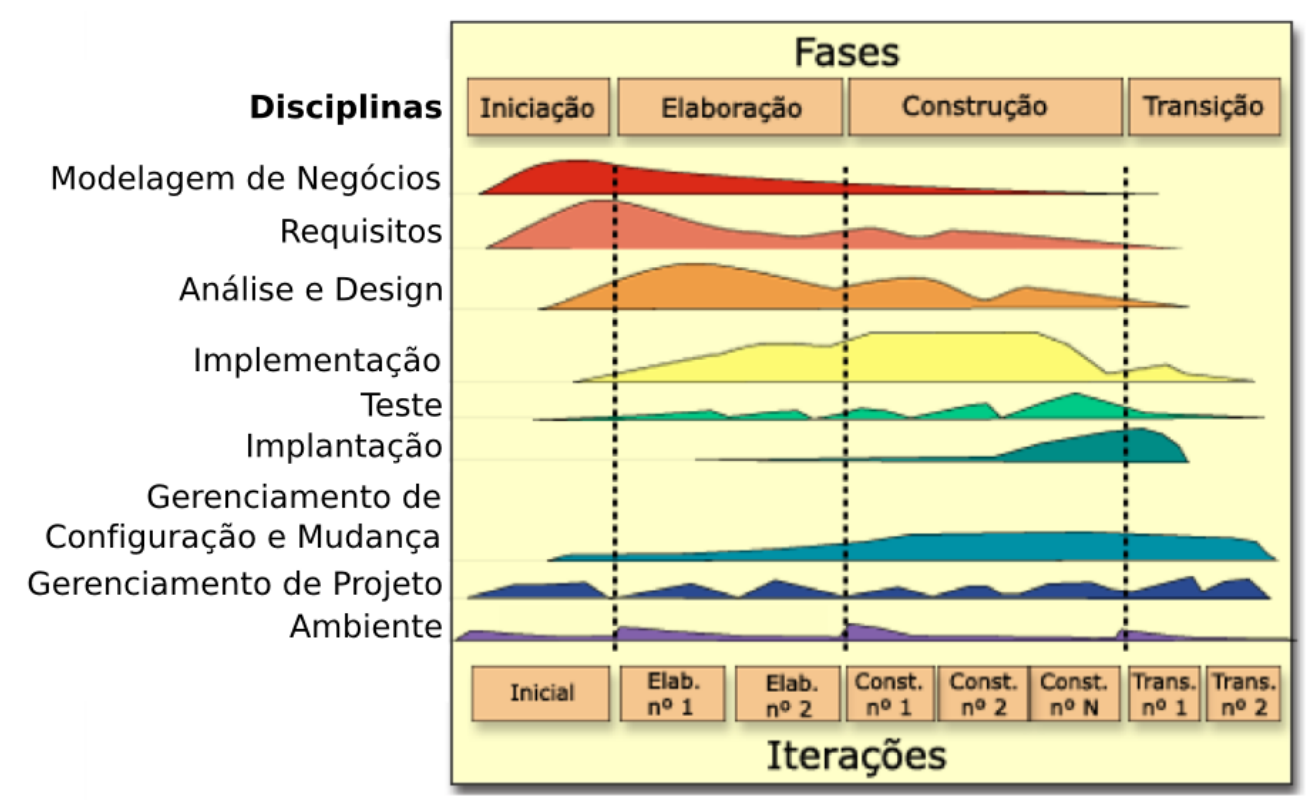

Figura 2.2: As fases do RUP e a distribuição do volume de atividades em cada uma delas [Rat].

\section{Práticas}

As práticas do Processo Unificado traduzem seus princípios em atividades que são realizadas pelo participantes. Apesar de haver inúmeras, seis delas se destacam como mais importantes, pois reúnem o mínimo necessário para expressar a essência do processo [Kru03].

1. Utilize intervalos de tempo fixos (timebox) de duas a seis semanas para cada iteração realizando programação desde o início. Isso tornará o processo iterativo e as decisões serão embasadas pelo conhecimento ganho a partir do esforço de programação. O software poderá ser adaptado à medida que o conhecimento sobre os requisitos aumentar e os maiores riscos forem descobertos ou minimizados.

2. Foque em desenvolver primeiro os requisitos de alto risco e alto valor e reaproveite componentes prontos, pois eles também diminuem o risco uma vez que o código já foi testado. 
3. Verifique a qualidade constantemente. Desenvolva, crie testes, execute testes e integre o código freqüentemente. Valide também a qualidade do processo através de reuniões de reflexão sobre o andamento do desenvolvimento.

4. Rascunhe a iteração. Antes de começar a programar, desenhe e discuta os principais pontos da modelagem. Para isso, diagramas UML podem ser esboçados em uma lousa ou criados com ajuda de ferramentas CASE.

5. Gerencie os requisitos. Descubra os requisitos iterativamente e, com auxílio de uma ferramenta, organize-os, refine-os e acompanhe os seus estados.

6. Gerencie mudanças definindo regras para alterações e as mantenha atualizadas.

\subsection{Processos Prescritivos e Processos Empíricos}

Processos que tentam prescrever cada passo da construção de um software são a base das metodologias tradicionais. Neles as etapas e as regras estão claramente definidas. Cada pessoa exerce um papel dentro do processo e cada papel possui responsabilidades específicas que limitam o campo de atuação dos envolvidos.

O objetivo por trás dessa rigidez é facilitar a replicação do processo em diversos ambientes, pois ele trata as pessoas como recursos facilmente substituíveis que podem exercer suas atividades independentemente do contexto. Assim, o processo teoricamente elimina o risco associado a erros humanos, pois as tarefas seguirão as especificações determinadas pelo processo.

A inconsistência desta abordagem é a tentativa de tornar uma atividade inerentemente feita com a criatividade humana em uma atividade mecanicamente replicável. Se o desenvolvimento de sistemas de software fosse uma operação determinística, as pessoas que participam do processo poderiam ser substituídas por máquinas ou programas de computador.

Processos rígidos transferem o foco da produção do sistema para si ao fazerem com que as pessoas e o projeto tenham que se adequar a eles. Tentar tirar dos indivíduos a responsabilidade pela produção do software não faz sentido em um contexto em que eles são fundamentais, uma vez que: pessoas sem processos podem produzir software, mas processos sem pessoas não produzem.

Metodologias ágeis apóiam-se em poucas regras rigidamente definidas e em princípios que oferecem certa flexibilidade para que as práticas do dia-a-dia sejam adaptadas. 
No contexto ágil, os processos caracterizam-se como empíricos e adaptativos. A principal influência para os processos ágeis é o modelo de melhoria contínua de qualidade que Eduwards Deming criou nos anos 50 baseado no modelo estatístico de controle de qualidade proposto por Walter Shewhart na década de 20. Os dois trabalharam juntos na indústria japonesa e contribuíram decisivamente para sua ascensão. O ciclo proposto por Eduwards é composto por quatro etapas que se repetem continuamente: Planejamento, Execução, Verificação e Ação. Este processo ficou mundialmente conhecido como Ciclo de Deming [Dem86]. O diagrama da Figura 2.3 apresenta a interação entre suas etapas e a Tabela 2.1 seus principais objetivos.

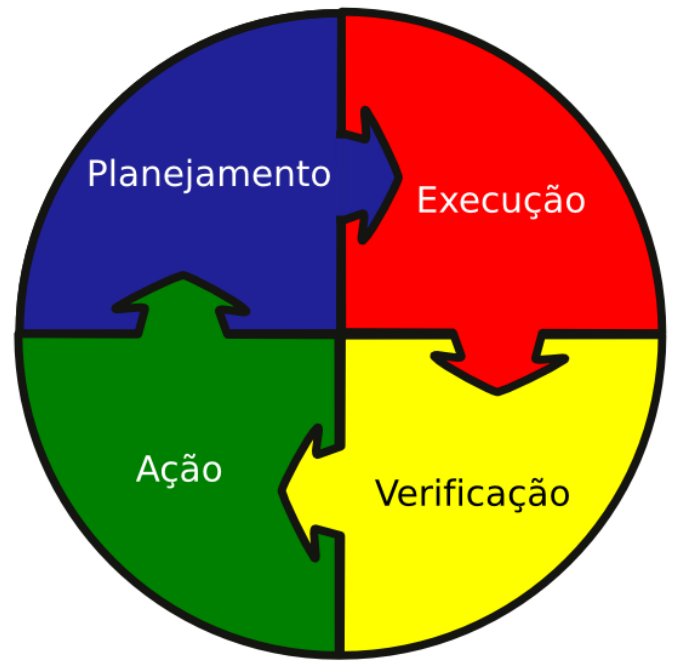

Figura 2.3: Ciclo de melhoria contínua de Deming.

\begin{tabular}{ll}
\hline Etapa & Objetivos \\
\hline Planejamento & $\begin{array}{l}\text { Definir objetivos; estabelecer um caminho para atingir os ob- } \\
\text { jetivos; definir padrões; escolher os métodos e ferramentas. }\end{array}$ \\
\hline Execução & $\begin{array}{l}\text { Treinar e aprender os métodos escolhidos; executar o plane- } \\
\text { jado; coletar dados para avaliação. }\end{array}$ \\
\hline Verificação & $\begin{array}{l}\text { Verificar se os padrões estão sendo seguidos; analisar os dados } \\
\text { coletados; avaliar se os objetivos foram atingidos. }\end{array}$ \\
\hline \multirow{2}{*}{ Ação } & $\begin{array}{l}\text { Investigar as razões dos problemas; se necessário, tomar ações } \\
\text { para atender os padrões estabelecidos; corrigir os problemas } \\
\text { e tomar ações para evitar que eles reapareçam; identificar } \\
\text { maneiras de melhorar o processo de trabalho. }\end{array}$ \\
\hline
\end{tabular}

Tabela 2.1: Objetivos das etapas do Ciclo de Deming. 


\subsection{Métodos Ágeis}

A seguir, vamos descrever os principais métodos ágeis, dando ênfase para aqueles que mais influenciaram nosso trabalho.

\subsubsection{Origem dos Métodos Ágeis}

Durante a evolução dos processos de Engenharia de Software, a indústria se baseou nos métodos tradicionais de desenvolvimento de software, que definiram por muitos anos os padrões para criação de software nos meios acadêmico e empresarial. Porém, percebendo que a indústria apresentava um grande número de casos de fracasso, alguns líderes experientes adotaram modos de trabalho que se opunham aos principais conceitos das metodologias tradicionais. Aos poucos, foram percebendo que suas formas de trabalho, apesar de não seguirem os padrões no mercado, eram bastante eficientes. Aplicando-as em vários projetos, elas foram aprimoradas e, em alguns casos, chegaram a se transformar em novas metodologias de desenvolvimento de software. Essas metodologias passaram a ser chamadas de leves por não utilizarem as formalidades que caracterizavam os processos tradicionais e por evitarem a burocracia imposta pela utilização excessiva de documentos. Com o tempo, algumas delas ganharam destaque nos ambientes empresarial e acadêmico, gerando grandes debates, principalmente relacionados à confiabilidade dos processos e à qualidade do software.

Depois de muitos anos de experiência, 17 desses líderes que trabalhavam no contra-fluxo dos padrões da indústria de software perceberam que seus modos de trabalho, além de eficazes, eram parecidos uns com os outros. Em 2001, eles se reuniram durante um final de semana em uma estação de ski em Utah para discutir sobre suas formas de trabalho e para chegar a uma nova metodologia de produção de software que pudesse ser usada por todos eles e em outras empresas, substituindo os modelos tradicionais de desenvolvimento.

Após dois dias de debate, o grupo não chegou a uma metodologia: concluíram que desenvolver software é algo complexo demais para ser definido por um único processo, pois ele depende de muitas variáveis e principalmente por ser uma tarefa inerentemente realizada por pessoas em praticamente todas as etapas do processo. No entanto, o grupo chegou ao consenso de que alguns princípios eram determinantes para a obtenção de bons resultados. O resultado deste encontro foi a identificação de 12 princípios e a publicação do Manifesto Ágil $\left[\mathrm{BBvB}^{+} 01\right]$ que os representa com quatro premissas: 
- Indivíduos e iterações são mais importantes do que processos e ferramentas

- Software funcionando é mais importante do que documentação completa

- Colaboração com o cliente é mais importante do que negociação de contratos

- Adaptação a mudanças é mais importante do que seguir o plano inicial

Kent Beck, Mike Beedle, Arie van Bennekum, Alistair Cockburn, Ward Cunningham, Martin Fowler, James Grenning, Jim Highsmith, Andrew Hunt, Roland Jeffries, Jon Kern, Brian Marick, Robert C. Martin, Steve Mellor, Ken Schwaber, Jeff Sutherland e Dave Thomas [BBvB $\left.{ }^{+} 01\right]$

O Manifesto Ágil ressalta o que mais tem valor para as metodologias ágeis. Processos, contratos, documentação e planejamento têm valor para o desenvolvimento de software, mas são menos importantes do que saber como lidar com pessoas, do que ter o cliente colaborando para encontrar a melhor solução, do que entregar o software com qualidade e do que se adaptar às mudanças [KR02].

As metodologias, então chamadas de ágeis, propõem a obtenção de resultados práticos em um período menor do que a indústria de software estava acostumada, tirando o foco do processo e o colocando no produto. Para isso, foi preciso que os métodos ágeis dispensassem ou modificassem as etapas do processo e a forma como os envolvidos com o desenvolvimento realizavam suas atividades. Muitas dessas mudanças alteraram características tidas como essenciais pelos métodos tradicionais, por isso as abordagens ágeis tornaram-se polêmicas e não inspiraram confiança nos mais conservadores.

Por outro lado, o foco dos modelos ágeis no produto final e nos interesses de negócio tem despertado interesse de outra parcela da comunidade de desenvolvimento de software. Desde sua publicação até novembro de 2007, o Manifesto Ágil teve 7.378 pessoas que o assinaram publicamente em http://www.agilemanifesto.org. Além disso, o número de adeptos de metodologias ágeis vem crescendo pelo mundo. A Scrum Alliance possui 18.225 associados que pagaram para obter certificações em desenvolvimento e treinamento usando Scrum [Scr] e o DSDM Consortium possui 118 instituições associadas que utilizam essa metodologia [DSD $]^{4}$. Contudo, apesar da expansão e do amadurecimento desses métodos pelo mundo, eles ainda são utilizados na menor parte das empresas. Algumas utilizam apenas poucas práticas, mas a maioria ainda utiliza modelos tradicionais.

\footnotetext{
${ }^{4}$ Todos os dados sobre o Manifesto Ágil, a Scrum Alliance e o DSDM Consortium foram coletados em 10/11/2007.
} 


\subsubsection{Características Comuns}

Algumas características estão presentes em muitos dos métodos ágeis ou podem ser usadas independentemente da metodologia escolhida, por isso optamos por apresentá-las antes e, em alguns casos, ressaltamos como elas diferem de características equivalentes em métodos tradicionais. Depois, na descrição dos métodos, explicamos as práticas que concretizam esses conceitos.

\section{Testes}

Métodos tradicionais tratam a implementação e os testes como fases completamente distintas. Em métodos ágeis, esta segmentação tende a desaparecer. Implementação e testes acontecem muitas vezes juntos: o mesmo programador cria o código e também o testa.

A produção de testes no início do projeto facilita a identificação de problemas e reduz o custo de desenvolvimento do software. Boehm et al. apontam que o custo de encontrar e corrigir erros depois que o software foi entregue pode chegar a 100 vezes mais do que durante as fases de exploração

e design $\left[\mathrm{BAB}^{+} 00\right]$. Por isso, em alguns métodos ágeis o conceito de cedo é levado ao extremo usando uma técnica que cria os testes antes da implementação, o Desenvolvimento Dirigido por Testes (Test Driven Development, TDD), com um ciclo de testes e implementação que dura apenas alguns minutos [Bec03]. Jeffries e Grigori reuniram vários relatos de uso de TDD destacando os ganhos de qualidade com esta técnica e o esforço extra para a equipe implementá-la [JM07].

Criando testes desde o início do projeto, a equipe pode realizá-los com freqüência para certificarse de que o software continua sempre atendendo aos requisitos. Para facilitar a realização freqüente dos testes, metodologias ágeis os produzem no formato de testes automatizados, assim eles podem ser executados facilmente a qualquer momento e, em especial, sempre que novas implementações forem realizadas.

\section{Desenvolvimento Iterativo}

O desenvolvimento acontece em ciclos (iterações), que têm o objetivo de produzir e integrar partes do software. Cada iteração pode durar desde alguns meses até poucas horas, conforme a metodologia escolhida e as habilidades da equipe. Desta forma, o processo torna-se flexível para acomodar mudanças funcionais e de prioridade durante a construção do sistema. No fim de cada ciclo, o software pode ser entregue ao cliente para que o restante do desenvolvimento seja direcionado pelo seu feedback. 


\section{Desenvolvimento Incremental}

Durante as iterações, o software pode receber incrementos funcionais de duas formas: 1) acrescentando funcionalidades à medida que o software cresce, ou 2) evoluindo as funcionalidades junto com o sistema. Na primeira, as funcionalidades são implementadas completamente e entregues uma por vez, no segundo caso elas são criadas de forma simplificada para entrarem em produção rapidamente e, se preciso, são completadas ou melhoradas nas próximas iterações.

\section{Colaboração}

Clientes e usuários estão mais próximos dos desenvolvedores e acompanham a evolução do produto. O contato constante com o cliente permite feedback rápido e facilita a comunicação. Com mais comunicação, a visão dos participantes sobre o andamento do projeto torna-se mais apurada, evitando que surpresas aconteçam no fim do projeto. A identificação e resolução de problemas tornam-se mais rápidas e as prioridades, o escopo e os detalhes da implementação podem ser negociados com mais facilidade.

\section{Estimativas}

Métodos ágeis usam estimativas ao invés de predições. Estimativas são compostas por uma dupla de valores $\langle v, p\rangle$, onde $v$ é um palpite sobre determinado evento ou atividade e $p$ é a probabilidade de $v$ acontecer.

Equipes ágeis baseiam-se na comunicação e na transparência. Ao invés de tratar suas estimativas como fatos, admitem que existe uma incerteza associada ao valor estimado e evidenciam isso para que o cliente e outros envolvidos também tomem ciência do grau de dificuldade de cada tarefa.

Estimativas de longo prazo geralmente possuem graus maiores de incerteza associados. À medida que o tempo passa e o conhecimento sobre o assunto aumenta, as estimativas podem ser refeitas considerando um nível maior de detalhes e associando probabilidades de sucesso mais altas.

Cada funcionalidade, ou grupo de funcionalidades, é estimado usando uma escala com valores preestabelecidos. Cohn [Coh06] sugere o uso de escalas com números de Fibonacci (1, 2, 3, 5, 8, $13, \ldots)$ ou com potências de $2(1,2,4,8,16,32, \ldots)$, pois são seqüências exponenciais que irão absorver parte do erro e da incerteza associada às estimativas de tarefas grandes. Opcionalmente, a equipe pode incluir o 0 (zero) na escala para estimar tarefas triviais. Depois, muitas tarefas triviais 
podem ser agrupadas e receber tamanho 1, afinal, mesmo sendo triviais, tomarão algum tempo para serem realizadas.

A escala usada para estimar pode utilizar pontos, dias ideais ou horas de trabalho. Os pontos são medidas abstratas definidas pela equipe a partir de uma tarefa pequena que ela considera como sua unidade, os demais valores da escala são atribuídos às funcionalidades por comparação com esta unidade. Um dia ideal é o quanto seria produzido em um dia de trabalho se $100 \%$ do tempo fosse dedicado a uma atividade, sem interrupções ou distrações. Para este caso, a equipe precisa perceber a porcentagem de tempo que ela, de fato, se dedica ao projeto, para obter o fator de conversão entre dias ideais e dias reais. As horas de trabalho apontam quanto tempo será preciso para concluir cada tarefa. Esta medida é geralmente usada para chegar ao custo do desenvolvimento.

Os pontos e os dias ideais fornecem estimativas de tamanho, que são medidas sobre o volume de trabalho. Além dessas, é interessante obter estimativas de duração, como por exemplo, horas de trabalho, que prevêem a quantidade de tempo necessária para realizar a tarefa. Medidas de duração podem ser obtidas a partir da velocidade da equipe, que é a quantidade de pontos que ela consegue concluir a cada iteração.

De qualquer forma, é importante que medidas de tamanho e duração fiquem separadas, pois a velocidade da equipe pode variar durante o projeto. Isso influencia as estimativas de duração, que são as que os clientes estão mais interessados, e obriga a equipe a refazê-las. Baseando as estimativas no tamanho, quando a velocidade de desenvolvimento mudar, basta identificar a nova velocidade e derivar as novas estimativas de duração.

\section{Negociação}

No desenvolvimento de software, o planejamento e o produto final estão relacionados com quatro variáveis interdependentes: tempo, custo, escopo e qualidade, onde o custo é definido pelo tamanho da equipe de desenvolvimento, Essas variáveis se relacionam de forma que a alteração do valor de qualquer uma delas influencia as outras [BF01]. Portanto, assumindo essa dependência, podemos representar essas relações através de uma equação:

$$
\alpha \cdot \text { Qualidade }+\beta \cdot \text { Custo }=\gamma \cdot \text { Tempo }+\delta \cdot \text { Escopo }
$$

onde $\alpha, \beta, \gamma$ e $\delta$ são constantes não-negativas. 
Agora, considerando as variáveis duas a duas e fixando o valor das demais, a Tabela 2.2 mostra o seu comportamento quando uma delas sofre alteração. Os símbolos "+" e "-" representam, respectivamente, se a variação de uma delas muda direta ou inversamente o valor da outra, ou seja, se o aumento da primeira eleva ou reduz o valor da segunda.

\begin{tabular}{r|c|c|c|c}
\hline & Tempo & Custo & Qualidade & Escopo \\
\hline Tempo & + & - & + & + \\
\hline Custo & - & + & + & + \\
\hline Qualidade & + & + & + & - \\
\hline Escopo & + & + & - & + \\
\hline
\end{tabular}

Tabela 2.2: Relação de dependência entre variáveis do projeto, analisadas duas a duas.

Da Tabela 2.2, percebemos que há apenas duas relações inversas, uma entre tempo e custo e outra entre qualidade e escopo. Para as outras relações, o aumento ou diminuição no valor de um dos lados, causa um efeito de mesma orientação na outra variável. Com essa análise vemos que não é razoável modificar essas variáveis isoladamente.

Métodos ágeis têm como objetivo sempre entregar software testado e com o mínimo de erros, por isso consideram a qualidade como uma variável fixa com valor alto. Supondo que a equipe esteja definida, o custo mensal da equipe também está. Desta forma, o planejamento e as negociações com clientes baseiam-se em ajustes no tempo e no escopo, duas variáveis diretamente relacionadas de muito interesse dos clientes, que tendem a querer aumentar o escopo e diminuir o tempo. Para evitar planejamentos e negociações inconsistentes, que diminuam o tempo sem mexer no escopo ou que aumentem o escopo sem mudar o prazo, modelos ágeis têm a proposta de guiar o desenvolvimento pelas prioridades de negócio, permitindo que o cliente primeiro defina as datas de entrega, desta forma, a negociação segue até clientes e desenvolvedores concordarem sobre o escopo.

\section{Priorização}

Métodos ágeis baseiam-se fortemente na adaptação a mudanças. As estratégias de planejamento focam em planos detalhados para o curto prazo e mais superficiais para o futuro distante. Desta forma, é possível uma visão panorâmica para guiar as decisões no longo prazo e precisão nas atividades do dia-a-dia. As duas principais vantagens desta abordagem são: 1) economia de esforço ao abrir mão do detalhamento de longo prazo, pois é difícil fazer previsões sobre o futuro e a alta chance 
de mudanças durante a execução invalida facilmente especificações minuciosas; 2) detalhes no longo prazo trazem a falsa sensação de certeza, pois os indivíduos passam a tratar previsões detalhadas como predições [PP03].

Equipes ágeis revêem seus planos constantemente. A cada planejamento, elas têm a oportunidade de avaliar as condições do projeto e, baseadas nesses fatos, traçar o melhor caminho para atingir seus objetivos. Esta estratégia mantém os planos e a execução sempre adequados à realidade, que inexoravelmente está em mutação. Isso significa identificar prioridades para cada momento do projeto.

Identificar prioridades nem sempre é óbvio ou natural. Jim Jonhson ressaltou as conseqüências de má priorização: $64 \%$ das funcionalidades raramente ou nunca são usadas [Joh02]. Isto explicitamente significa desperdício, pois essas funcionalidades poderiam não ter sido produzidas, ou sido substituídas por outras mais relevantes. Para resolver este problema, a priorização pode ser guiada pelo valor de negócio das funcionalidades. Algumas técnicas determinam as prioridades baseadas em estimativas de volume de trabalho, tempo de desenvolvimento e dificuldade de implementação (fornecidas pela equipe de desenvolvimento), combinadas com dependências associadas às regras de negócio e à visão do cliente. Em especial, destacamos três técnicas que utilizam esses dados como insumo para a obtenção das prioridades: a Ponderação por Pesos Relativos [Coh06], a Priorização por Valor $e$ Risco [Coh06] e o Modelo de Satisfação do Cliente [KSTT84].

A Ponderação por Pesos Relativos considera três valores para cada funcionalidade: o custo, representado pelas estimativas de tamanho (pontos) feitas pela equipe de desenvolvimento; o benefício definido pelo cliente considerando o valor que a funcionalidade agrega ao software; e uma penalidade, que corresponde a um potencial prejuízo caso a funcionalidade esteja ausente. Por exemplo, alguns sistemas da área médica e financeira precisam que todas as suas operações atendam a exigências legais. Do ponto de vista do usuário, essas conformidades são imperceptíveis, por isso o benefício dessa característica é muito baixo, ou zero, e a penalidade é alta, pois sua ausência implica um grande risco para o projeto ou para a empresa, expondo-a a multas e a processos jurídicos ou criminais.

Para priorizar as funcionalidades, percentuais de valor e custo são calculados. O percentual de valor (\%valor) de cada funcionalidade $f$ é obtido somando seus pontos de benefício e de penalidade, depois dividindo-os pela soma dos pontos de benefício e de penalidade de todas as funcionalidades do projeto, conforme a expressão a seguir:

$$
\text { ovalor }_{f}=\frac{\text { beneficio }_{f}+\text { penalidade }_{f}}{\sum_{k=1}^{n}\left(\text { beneficio }_{k}+\text { penalidade }_{k}\right)}
$$


O percentual do custo (\%custo) é calculado através da relação entre a quantidade de trabalho necessária para produzir cada funcionalidade $f$ com o esforço de produzir todas as funcionalidades, conforme a expressão abaixo:

$$
\% \text { custo }_{f}=\frac{\text { pontos }_{f}}{\sum_{k=1}^{n} \text { pontos }_{k}}
$$

A prioridade da funcionalidade $f$ é então obtida a partir da relação entre custo e valor através de seus percentuais, conforme a fórmula a seguir:

$$
\text { Prioridade }_{f}=\frac{\text { \%valor }_{f}}{\text { \%custo }}
$$

A Priorização por Valor e Risco considera estas duas variáveis: o valor de negócios e os riscos associados à implementação de cada funcionalidade. O cliente determina a primeira medida e a equipe de desenvolvimento a segunda. Por fim, ambas são expostas em um gráfico onde os eixos são justamente valor e risco (Figura 2.4). Para esta técnica não é preciso definir uma escala e pontuar valor e risco com precisão numérica porque ao dispô-los no gráfico, será possível visualizar as funcionalidades e, comparativamente, determinar as que mais agregam valor ou possuem incertezas.

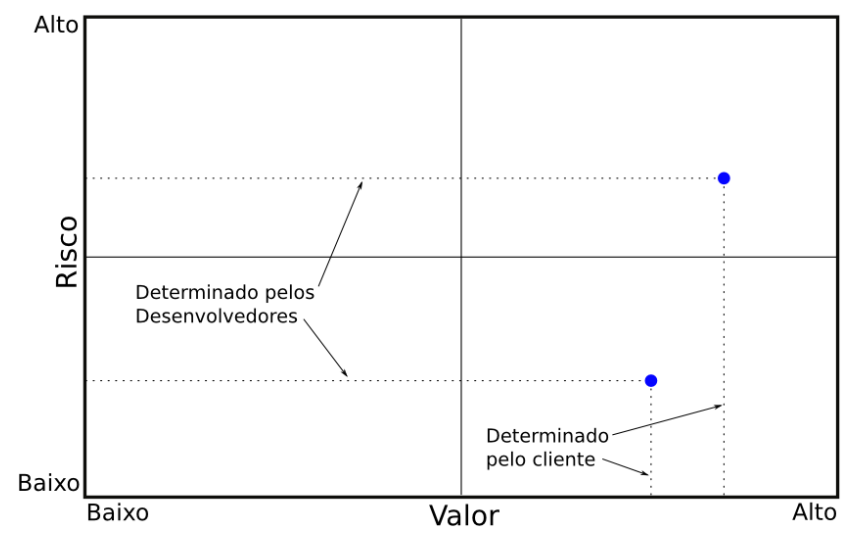

Figura 2.4: Exemplo de construção do gráfico de Valor e Risco.

Depois de dispor as funcionalidades no plano, este é dividido em quadrantes e uma estratégia de priorização é escolhida conforme a metodologia, o projeto e a experiência da equipe. Para projetos que precisam comprovar sua viabilidade ou equipes experientes com métodos ágeis, a prioridade 
mais alta pode ir para as funcionalidades do quadrante com valor e risco altos. Fazê-las primeiro é interessante porque quando estiverem concluídas, haverá uma grande quantidade de valor agregado ao software e ao mesmo tempo, uma grande quantidade de risco terá sido eliminada do projeto. Caso não seja possível produzi-las ou a dificuldade torne a implementação muito mais demorada do que o previsto, isso é identificado cedo e as estimativas podem ser ajustadas no início do projeto.

Em seguida, conforme a Figura 2.5, são feitas as funcionalidades do quadrante com alto valor e baixo risco, depois aquelas com baixo valor e baixo risco e, por último, se ainda forem necessárias, as funcionalidades de grande dificuldade que agregam pouco valor.

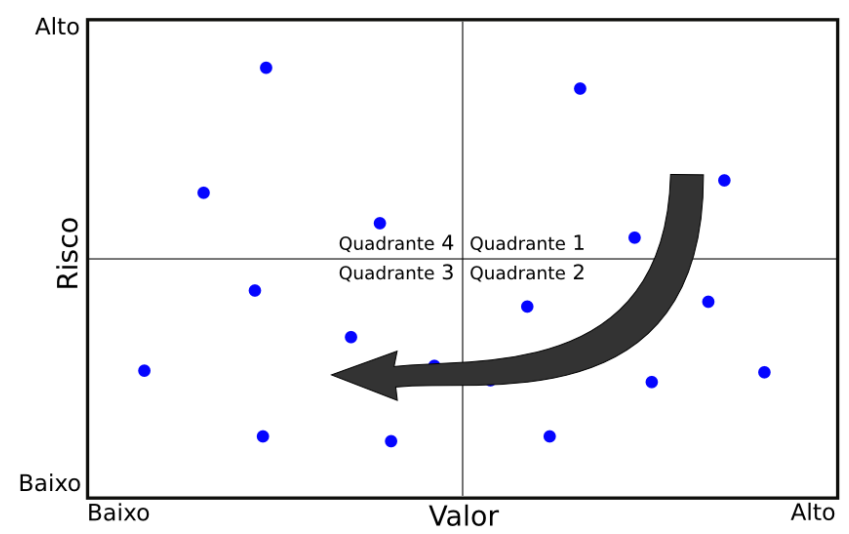

Figura 2.5: Prioridade dos quadrantes com foco na eliminação de risco.

Equipes com pouca experiência em desenvolvimento ágil ou projetos sem grandes desafios técnicos podem usar outra seqüência de priorização. Começando pelo quadrante 2, para produzir funcionalidades importantes e rapidamente chegar a uma versão do software em produção e, em seguida, implementado as funcionalidades dos quadrantes 1 e 3 e, se necessário, as do quadrante 4, conforme a Figura 2.6.

Algumas vezes, independente da seqüência de quadrantes escolhida, o último não chega a ser implementado porque o software já atende às necessidades dos usuários e o investimento para produzir funcionalidades de alto risco não é recompensado.

O Modelo de Satisfação do Cliente proposto por Noriaki Kano [KSTT84] para o desenvolvimento de produtos classifica as suas características em seis categorias de acordo com as preferências dos usuários. 


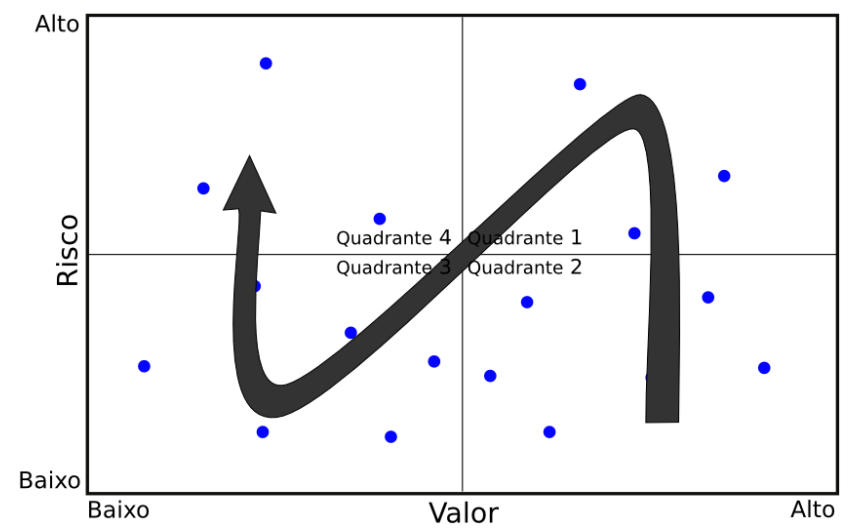

Figura 2.6: Prioridade dos quadrantes focada na entrega da primeira versão.

- Características Básicas: causam descontentamento se estiverem ausentes mas não levam à satisfação quando presentes.

- Características de Desempenho: a quantidade e a qualidade influem diretamente na satisfação, podendo levar o usuário à satisfação ou ao descontentamento.

- Características Excitantes: aumentam a satisfação quando presentes e não causam descontentamento se estiverem ausentes.

- Características Indiferentes: os clientes não se preocupam se elas estão presentes ou não.

- Características Invertidas: apontam que a preferência dos clientes é contrária ao modo como a característica proposta.

- Características Questionáveis: indicam respostas contraditórias, podendo evidenciar um erro na aplicação do modelo ou que há clientes que gostam e outros que não gostam da característica.

A presença de características básicas, excitantes e de desempenho afetam a satisfação do cliente. Na Figura 2.7, podemos ver como elas se relacionam.

Para identificar a qual categoria cada característica (ou funcionalidade, no caso de software) pertence, Kano recomenda a aplicação de duas perguntas sobre ela, uma funcional e outra disfuncional:

- Funcional: Como você se sentiria se esta característica estivesse presente? 


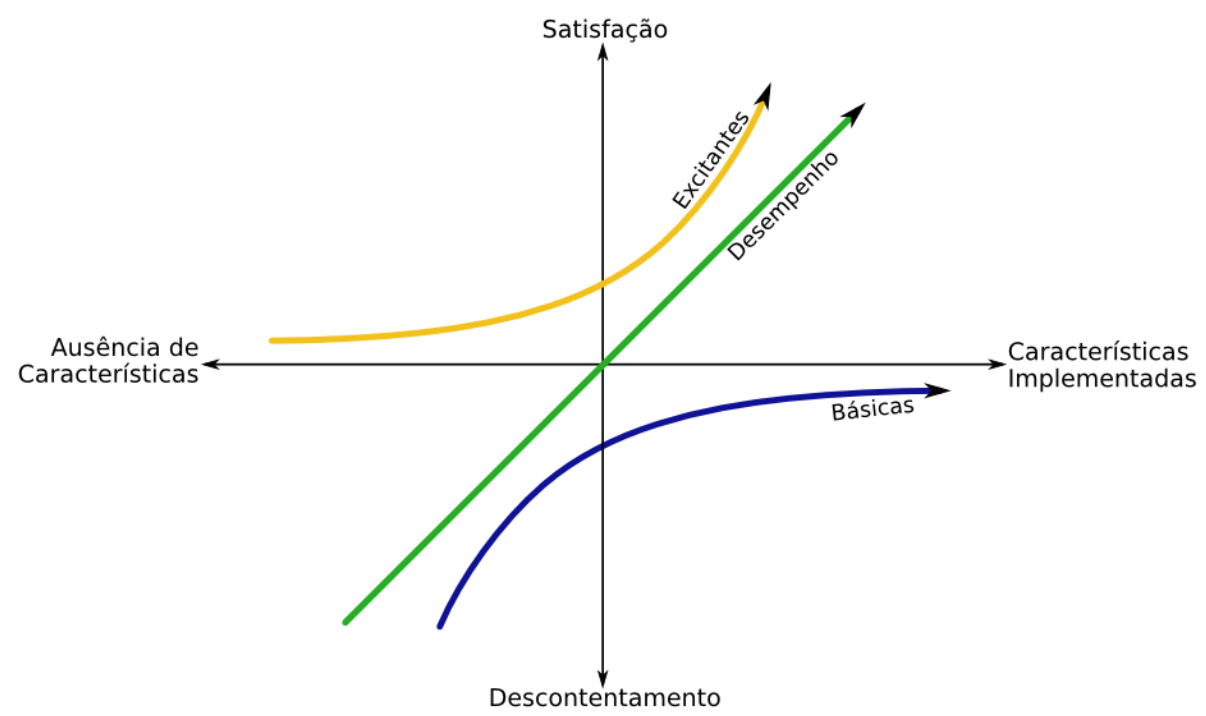

Figura 2.7: Relação entre a satisfação do cliente e a presença de características básicas, de desempenho e excitantes.

- Disfuncional: Como você se sentiria se esta característica não estivesse presente?

Para cada questão, o cliente deve escolher a resposta entre uma das cinco alternativas:

- 1 - Eu gostaria.

- 2 - Eu espero que ela esteja.

- 3 - Tanto faz.

- 4 - Tudo bem se ela estiver.

- 5 - Eu não gostaria.

O cruzamento das respostas no gabarito da Tabela 2.3 classifica a funcionalidade entre as categorias e portanto determina sua relação com a satisfação do cliente.

\subsubsection{Evolutionary Project Management - EVO}

Após anos de experiência em desenvolvimento de software, Tom Gilb foi um pioneiro do desenvolvimento de software usando processos evolutivos. Em uma época onde o modelo Cascata era 


\begin{tabular}{|c|c|c|c|c|c|c|}
\hline & \multicolumn{5}{|c|}{ Disfuncional } \\
\hline & & Gostaria & Espero & $\begin{array}{c}\text { Tanto } \\
\text { faz }\end{array}$ & $\begin{array}{l}\text { Tudo } \\
\text { bem }\end{array}$ & $\begin{array}{c}\text { Não } \\
\text { gostaria }\end{array}$ \\
\hline \multirow{5}{*}{ 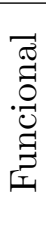 } & Gostaria & $\mathrm{Q}$ & $\mathrm{E}$ & $\mathrm{E}$ & $\mathrm{E}$ & $\mathrm{D}$ \\
\hline & Espero & $\mathrm{C}$ & $\mathrm{I}$ & $\mathrm{I}$ & $\mathrm{I}$ & $\mathrm{B}$ \\
\hline & Tanto faz & $\mathrm{C}$ & $\mathrm{I}$ & $\mathrm{I}$ & I & B \\
\hline & Tudo bem & $\mathrm{C}$ & I & I & I & B \\
\hline & Não gostaria & $\mathrm{C}$ & $\mathrm{C}$ & $\mathrm{C}$ & $\mathrm{C}$ & Q \\
\hline
\end{tabular}

$$
\begin{aligned}
& \mathrm{B}=\text { básica } \\
& \mathrm{D}=\text { desempenho } \\
& \mathrm{E}=\text { excitante } \\
& \mathrm{I}=\text { indiferente } \\
& \mathrm{C}=\text { invertida } \\
& \mathrm{Q}=\text { questionável }
\end{aligned}
$$

Tabela 2.3: Classificação das funcionalidades de acordo com as respostas dos usuários.

soberano, em 1976, publicou seu primeiro livro sobre desenvolvimento evolutivo, apresentando as primeiras idéias do EVO [Gil76]. Depois de ter contato com o trabalho de Deming [Dem86], Gilb refinou seus conceitos de evolução [Gil85], até que em 1988, publicou "Principles of Software Engineering Management" que se tornou um marco entre os processos evolutivos [Gil88]. Apesar de pouco difundida na indústria brasileira, a obra de Gilb foi a precursora de métodos iterativos tais como UP, Scrum e XP.

\section{Fases}

As fases de Evo foram inspiradas nos processos de produtividade e qualidade implantados por Deming e por Shewhart na indústria japonesa. A cada iteração, além de produzir o software, o processo preocupa-se fortemente em quantificar, estimar e medir o progresso para orientar as decisões da próxima etapa de planejamento e execução [She80, Dem86].

A entrega de um software está associada a identificar o que é valioso para os clientes. Gilb chama a tentativa de levantar todos os requisitos de uma só vez de big bang delivery [Gil88], que é dificultada pela instabilidade das funcionalidades e pela falta de conhecimento completo dos requisitos. Para evitar esse problema, EVO usa desenvolvimento incremental dividido em duas fases:

- Gerenciamento Estratégico - Os donos do projeto analisam o que foi entregue e o que ainda há por ser feito e adaptam as metas da próxima entrega e do projeto. As funcionalidades prontas são avaliadas e podem, ou não, ser entregues aos usuários.

- Desenvolvimento - Dois tipos de entrega podem acontecer. Primeiro, a equipe desenvolve, testa e integra o software, deixando-o à disposição para entrar em produção no backroom. 
Depois, quando o cliente decide de fato entregar os produtos aos clientes, eles passam para o frontroom, concentrando os esforços em realizar novos testes em ambiente de produção, instalá-los e orientar os usuários sobre a utilização. No fim da iteração, o cliente redefine prioridades, revisa os requisitos e detalha os objetivos da próxima iteração. O gerente do projeto e os desenvolvedores identificam as dificuldades para melhorar o processo e o desempenho da equipe através das experiências da iteração anterior.

\section{Práticas}

O principal enfoque acontece nos aspectos gerenciais do projeto. A combinação das práticas abaixo facilita o direcionamento do desenvolvimento conforme os interesses de negócio, adaptando o processo através de iterações curtas.

- Identifique os envolvidos - Para produzir um software adequado, é importante saber quem são os envolvidos em sua criação para que o andamento do projeto seja guiado pelos interesses de negócio.

- Mitigação de riscos - Os ciclos de iterações e entregas devem ser curtos, consumindo de 2 a $5 \%$ do tempo e recursos totais do projeto. Dessa forma, o feedback é colhido rapidamente e quando uma iteração ou entrega não tem sucesso, ela terá consumido no máximo $5 \%$ dos recursos do projeto.

- Planguage - O uso de Planguage [Gil89], a linguagem de especificação do EVO, permite reunir informações de forma sintética junto com a descrição de funcionalidades e definição de testes, dependências, metas de desempenho, detalhes da arquitetura, histórico de decisões e alternativas para a implementação.

- Evolução do planejamento - As prioridades, custos e riscos devem ser reavaliados no fim de cada iteração, levando em conta medidas tiradas no decorrer do projeto. Assim, o planejamento para a próxima iteração é feito com base em informações atualizadas e com auxílio da experiência adquirida pela equipe. Análises de impacto considerando soluções alternativas são recomendadas para ajudar a tomar decisões.

- Evolução da arquitetura - A definição e o detalhamento da arquitetura deve acontecer incrementalmente durante as iterações. Opções arquiteturais, de implementação e explicações 
que descrevem como a versão atual atende aos requisitos podem manter-se presentes na documentação de especificação, que é refinada no decorrer do projeto.

- Inspeção de especificações - O controle de qualidade das especificações é feito com inspeções e aprovações através de técnicas de controle do processos da engenharia de software tradicional. As inspeções preocupam-se em assegurar a clareza dos documentos através de verificadores que avaliam as especificações e identificam pontos de melhoria.

\subsubsection{Dynamic Systems Development Method - DSDM}

No início da década de 90, depois de muitas frustrações com os atuais modelos de desenvolvimento, programadores e usuários estavam cansados de utilizar metodologias que não acompanhavam a velocidade das mudanças dos requisitos. Depois de mais de três décadas de trabalho na IBM, James Martin desenvolveu nos anos 80 o Rapid Application Development (RAD) [Mar91]. Na década de 90, a partir de sua disseminação pouco ordenada e do crescente interesse dos clientes em RAD, um grupo de 16 instituições se reuniu para definir e oficializar um padrão mais flexível para aplicação de RAD. O grupo criou o DSDM Consortium e, em 1995, lançou a primeira versão do arcabouço que definiu a implementação do DSDM [MS95]. No mesmo ano, após a experimentação da metodologia em projetos-piloto, a versão 2 já foi lançada. Ao longo dos anos, o foco do DSDM evoluiu conforme o mercado de software. Em 1997, a terceira versão foi desenvolvida a partir de mudanças propostas em um workshop organizado especificamente com o propósito de aprimorar o arcabouço. A atual versão 4.2 defende um modelo altamente interessado em refletir as perspectivas de negócio [SS03].

O DSDM Consortium centraliza os treinamentos corporativos e o material da metodologia, apresentando o DSDM para empresas que valorizam certificações como uma alternativa ao ISO 9001.

\section{Princípios}

O DSDM baseia-se em princípios ao invés de regras, focando em uma estratégia exploratória e iterativa. Os princípios apoiam-se na idéia de desenvolvimento iterativo e em uma intensa colaboração entre o cliente e a equipe de desenvolvimento. A filosofia do DSDM prega que softwares não são desenvolvidos perfeitamente da primeira vez, por isso as iterações e a colaboração servem para chegar gradativamente ao resultado esperado. Os nove princípios de sua filosofia são:

1. O envolvimento ativo dos usuários é imperativo. 
2. A equipe precisa ter poder para tomar decisões.

3. Foco em entregas freqüentes.

4. Alinhamento com os interesses de negócio.

5. Desenvolvimento iterativo e incremental para chegar a soluções apuradas.

6. Todas as mudanças de desenvolvimento devem ser reversíveis.

7. Requisitos são definidos em alto nível.

8. Testes são integrados durante o desenvolvimento.

9. Colaboração e cooperação entre todos os clientes é essencial.

Os princípios 1, 2, 3, 4, 5, 8 e 9 são semelhantes aos de outras metodologias ágeis que apresentamos. O princípio 6 prevê a criação de um ambiente de desenvolvimento onde a equipe sinta-se confortável para decidir sem medo de errar. Com mais auto-confiança a equipe terá coragem para tomar decisões mais rapidamente. O princípio 7 considera a certeza de que os requisitos irão mudar e que não é possível saber tudo a respeito deles de antemão. Assim, o detalhamento dos requisitos é postergado ao máximo para evitar que eles fiquem desatualizados.

\section{Processo}

Um projeto que usa DSDM começa com um estudo de viabilidade seguido pelo estudo de mercado e negócios que servem de base para as etapas incrementais do projeto. Na Figura 2.8, extraída de [Con], as três fases iterativas do processo são representadas por círculos: a iteração do modelo funcional, a iteração de design e a implementação. As setas indicam que além da iteratividade dentro de cada uma das fases, as três são iterativas também entre si. Com experiência, esse modelo permite a criação de planos altamente flexíveis para o projeto.

As iterações do modelo funcional priorizam a identificação dos requisitos funcionais e não-funcionais mais importantes, que preferencialmente documentados na forma de protótipos, ao invés de texto. As iterações de design refinam os protótipos identificando e acrescentando mais requisitos para serem implementados no terceiro ciclo iterativo. Quando as iterações de implementação acabam, o projeto pode voltar a qualquer uma das outras etapas, inclusive para o estudo de viabilidade. 


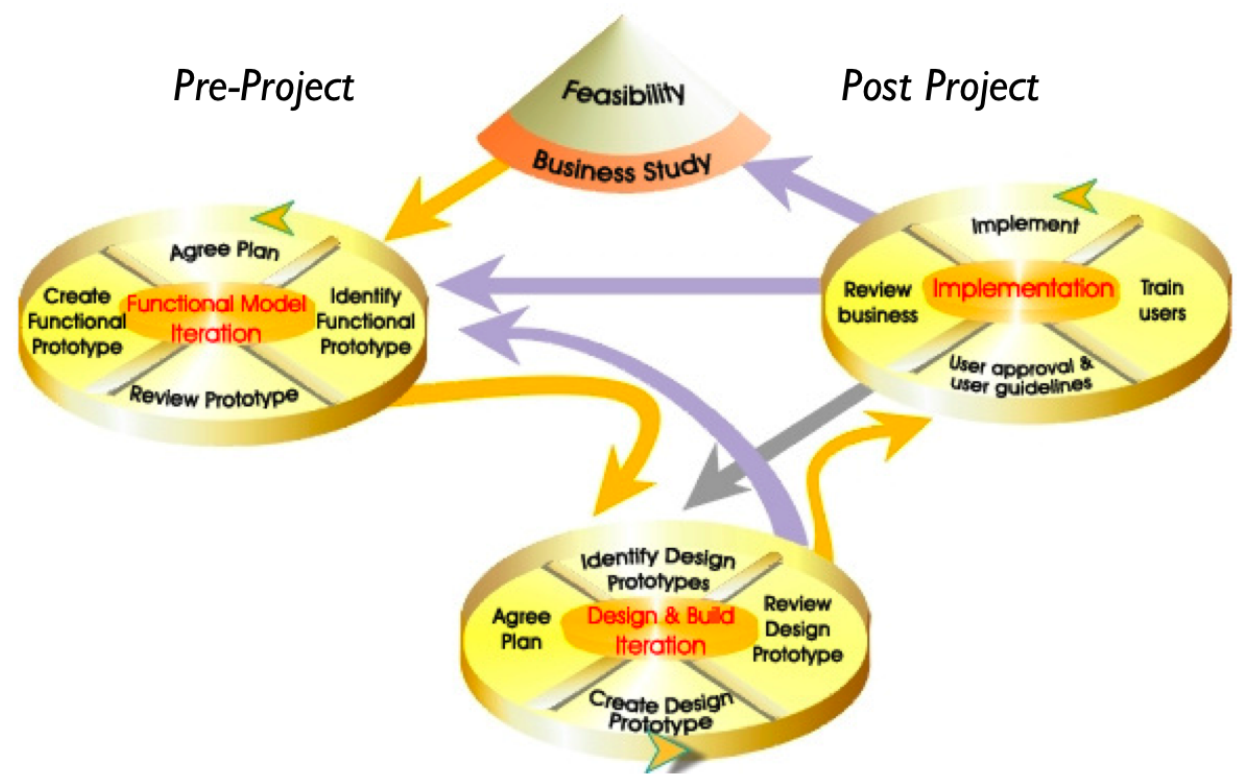

Figura 2.8: Processo DSDM.

O processo como um todo é fortemente baseado em prototipação. Tipos variados de protótipos podem ser criados para avaliar a usabilidade, performance, capacidade, explorar novas tecnologias ou investigar áreas com muita incerteza. Algumas vezes os protótipos podem ser testes de programação ao modo como é feito na fase exploratória de XP, no entanto o protótipo não é descartado. No DSDM, o protótipo é uma versão inicial do software que será melhorado no futuro.

Cada uma das fases iterativas (funcional, design e implementação) pode passar por várias iterações antes do projeto avançar para a próxima fase. As iterações e as versões são definidas por time-boxes ${ }^{5}$ com tamanhos definidos conforme as características do projeto. Cada fase dura de 2 a 6 semanas, assim o processo oferece flexibilidade durante o avanço do projeto para adaptações nos planos e cria oportunidades para novos estudos de viabilidade e incorporação de novos requisitos.

\section{Material de Apoio}

Seguindo a filosofia minimalista, DSDM sugere que durante todo o ciclo de desenvolvimento sejam produzidos no máximo quinze artefatos, incluindo os protótipos. Nas orientações de como produzir

\footnotetext{
${ }^{5}$ intervalos fixos de tempo
} 
esses artefatos, são apresentados apenas propósitos, breves descrições e critérios de qualidade para cada um deles, dando liberdade para que cada empresa ou equipe personalize e complemente esses artefatos conforme a sua cultura.

\section{Papéis}

O DSDM define três tipos de papéis para usuários que interagem com a equipe de desenvolvimento: o usuário embaixador, que representa uma comunidade de usuários com interesses e necessidades específicas; o visionário, que mantém seu interesse nos objetivos de alto nível do software para que eles não sejam perdidos com as mudanças que acontecem no decorrer do projeto; e o orientador, que acompanha o desenvolvimento no dia-a-dia fornecendo detalhes do negócio para a equipe.

\subsubsection{Scrum}

Em um jogo de rugby, "scrum" é uma forma do time recolocar a bola em jogo. Na metodologia criada por Jeff Sutherland a partir do trabalho de Nonaka e Takeuchi [NT86] e formalizada em 1995 por Ken Schwaber [Sch95], a equipe de desenvolvimento trabalha unida com o objetivo de entregar o software funcional de alta qualidade. Neste modelo, a equipe se compromete com um objetivo e tem autonomia para definir a tática para chegar até ele.

Em modelos tradicionais, o desenvolvimento de software é visto como um processo definido. O que significa que, a partir de entradas, é possível produzir uma determinada saída e que isto pode ser repetido várias vezes sem diferenças expressivas. Porém, Ken Schwaber percebeu que a complexidade da produção de sistemas tornava essa abordagem inadequada ao problema em questão e que melhores resultados poderiam ser obtidos tratando o desenvolvimento de software como um processo empírico [Sch95]. A dificuldade de definir um modelo de produção de software capaz de suportar as inúmeras variações dos ambientes de desenvolvimento motivou Schwaber a unir-se a Jeff Sutherland e Mike Beedle para compilarem suas idéias e lapidar o Scrum como modelo ágil de desenvolvimento de software que agrupa um pequeno conjunto de simples regras gerenciais que dão liberdade à evolução empírica do processo de desenvolvimento [SB02].

Scrum atua principalmente na gerência do projeto, sem determinar como a equipe executará as tarefas de programação. Esta abordagem favorece a auto-organização da equipe e permite a integração com outras metodologias ágeis que foquem nas práticas de programação, como por exemplo, XP. Diversos relatos descrevem a combinação de Scrum e XP com sucesso [Kni07, PP05, Dan05]. 
Em 2003, Jensen e Zilmer relataram um caso de sucesso com Scrum distribuído usando práticas de XP [JZ03] e mais recentemente, Sutherland também descreveu um caso do mesmo tipo [SVBP07].

\section{Elementos de Apoio}

Os únicos elementos que a equipe produz para seguir a práticas de Scrum são cartões com as funcionalidades e gráficos de acompanhamento. Os cartões agrupados formam o Backlog do Produto e outros backlogs. Os gráficos são atualizados freqüentemente e devem refletir o estado do projeto.

- Backlog do Produto: Lista de todos os cartões de funcionalidades que o produto deve possuir e que ainda não foram implementadas.

- Backlog Selecionado: Um subconjunto de funcionalidades que o cliente escolheu a partir do backlog do produto para ser implementado no sprint atual e que não pode ser modificado durante o sprint ${ }^{6}$.

- Backlog do Sprint: Lista priorizada, obtida a partir da quebra dos cartões do backlog selecionado em tarefas menores.

- Backlog de Impedimentos: Lista dos obstáculos identificados pela equipe que não pertencem ao contexto do desenvolvimento.

- Gráficos de Acompanhamento: Gráficos que medem a quantidade de trabalho restante (burndown charts) são os preferidos em Scrum. É recomendado fazê-los para várias esferas do projeto: para o produto, para a release e para o sprint.

\section{Papéis}

Poucos papéis caracterizam o Scrum. Apenas três estão presentes na metodologia:

Dono do Produto: O dono do produto deve possuir a visão do produto em vários níveis. A visão de longo prazo é mantida com o gerenciamento do backlog e a de curto prazo através da definição do objetivo do Sprint Selecionado. Quando existe vários interessados ou envolvidos com o produto, o dono do produto deve ser representado por uma só pessoa que entenda todas as necessidades e seja capaz de priorizá-las.

\footnotetext{
${ }^{6}$ Um sprint é equivalente a uma iteração, na página 41 mais detalhes são apresentados.
} 
Equipe: A equipe de desenvolvimento é vista como uma unidade dentro da metodologia. Ela deve ser multi-funcional e auto-suficiente, o que significa que seus membros devem reunir todas as habilidades necessárias para atingir o objetivo, assumindo compromissos e responsabilidades em relação ao projeto. Seus membros devem trabalhar em equipe para, juntos, atingir o objetivo. Uma equipe de desenvolvimento Scrum deve ser auto-organizada: cada membro deve saber que seu trabalho é igual e essencialmente importante para o sucesso de todos. Não existe hierarquia, cada um deve possuir consciência de sua responsabilidade para com a meta e pessoas sem comprometimento devem deixar a equipe.

ScrumMaster: O ScrumMaster deve possuir conhecimento de todo o processo para garantir que ele seja seguido e deve manter uma ampla visão sobre o projeto. Assim, pode auxiliar o dono do produto a tomar decisões que conduzam o projeto a obter o máximo retorno e aconselhar a equipe com suas escolhas. É responsabilidade do ScrumMaster eliminar os itens do backlog de impedimentos, fazer gráficos de acompanhamento da evolução do projeto e proteger a equipe contra instabilidades e fatores externos que prejudiquem seu rendimento.

\section{Fases}

Scrum caracteriza-se como um processo empírico e adaptativo. Suas iterações baseiam-se fortemente no Ciclo de Deming. As fases do Scrum, Planejamento, Sprint e Avaliação, correspondem, respectivamente, aos três primeiros estados do ciclo evolutivo do processo. A etapa de ação acontece no Scrum com mudanças no próximo planejamento baseadas nas conclusões da última avaliação.

O primeiro planejamento pode durar desde dias até algumas semanas, o tempo necessário para a equipe conhecer satisfatoriamente as características do produto que será desenvolvido e escolher as tecnologias e ferramentas de trabalho. Os planejamentos seguintes têm duração de aproximadamente dois dias, nos quais três reuniões são realizadas: uma para estimar, outra para definir a meta do sprint e a terceira para definir as tarefas necessárias para atingir a meta. A cada sprint, o dono do produto se baseia nas prioridades de negócio para escolher uma parte do backlog para compor o backlog selecionado. A equipe pode concordar com a seleção ou negociar os itens até que se comprometa a produzi-los durante o sprint.

Na reunião de estimativa, a equipe se reúne para estimar a quantidade de trabalho dos itens mais prioritários do backlog do produto com a presença do ScrumMaster e do dono do produto para esclarecer dúvidas referentes às regras de negócio. Depois, na primeira reunião de planejamento do 
sprint (Figura 2.97 , Sprint Planning 1), todos se reúnem para definir a meta do sprint e criar o backlog selecionado de acordo com as prioridades de negócio estabelecidas pelo dono do produto. Em seguida, na segunda reunião de planejamento do sprint (Figura 2.9, Sprint Planning 2), a equipe se reúne para quebrar os itens do backlog selecionado em tarefas de implementação de menor granularidade.

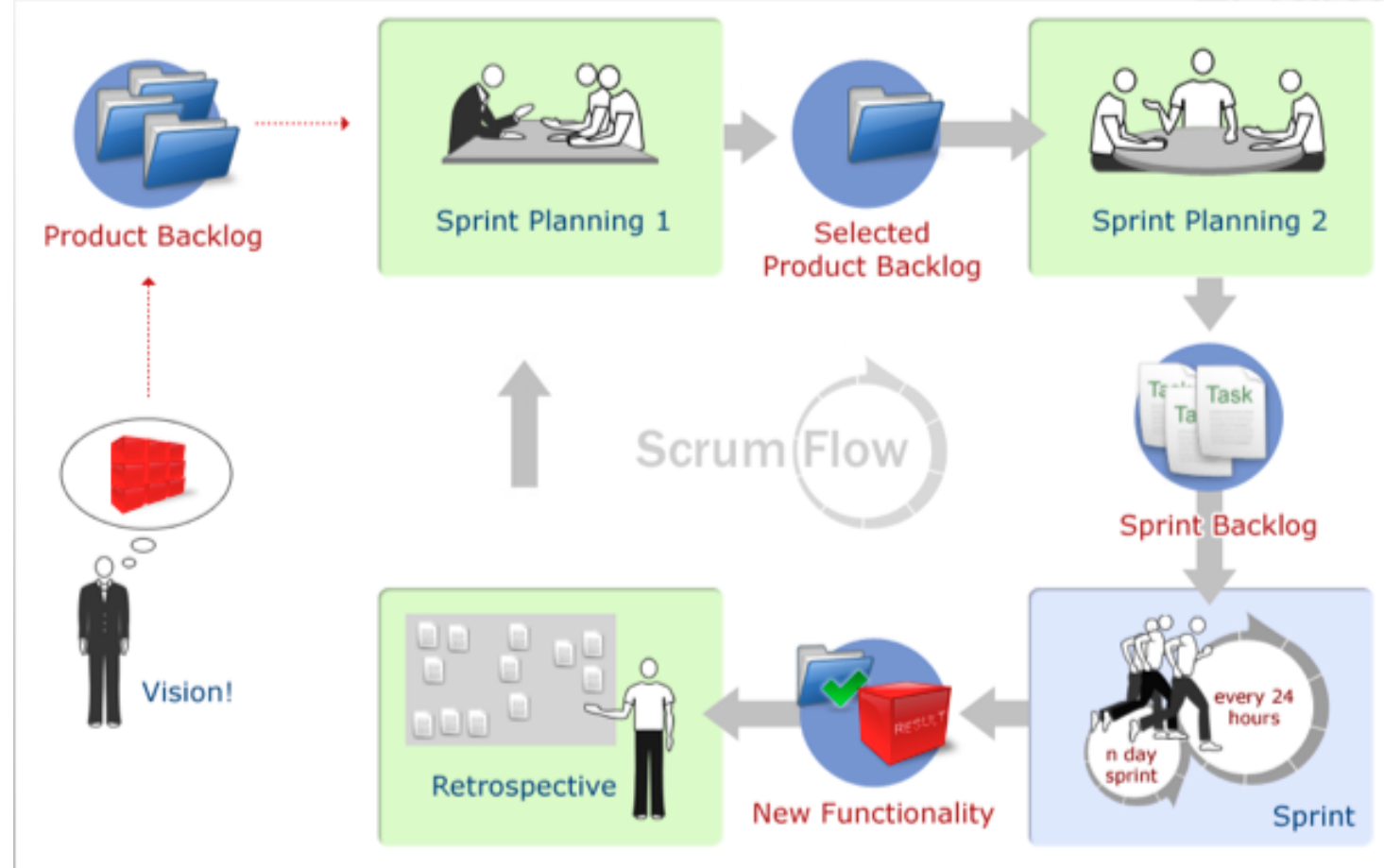

Figura 2.9: Ciclo de desenvolvimento do Scrum.

O sprint (Figura 2.9, Sprint) é a fase de implementação em que a equipe irá trabalhar unida para atingir o objetivo de entregar a parte do software que está no backlog selecionado. Inicialmente esta fase era recomendada num tamanho padrão de 30 dias corridos; atualmente a duração é definida conforme características do projeto e da equipe. É comum encontrar sprints de duas ou três semanas [Sch04,SVBP07,Dan05]. Sobretudo, é aconselhável que dentro de um projeto todos tenham o mesmo tamanho para que seja mais fácil determinar a velocidade da equipe. Durante o sprint, o ScrumMaster assegura que os itens do backlog selecionado não mudarão e elimina os itens do backlog de impedimentos para garantir que a equipe mantenha-se focada em seu objetivo. O dono do produto

\footnotetext{
${ }^{7}$ Obtida em http://corporate.sprint-it.de/sprint-it//scrum-flow/id=20, cid=28, lang=de, último acesso: $31 / 01 / 2008$
} 
acompanha o desenvolvimento e esclarece eventuais dúvidas, sem poder mudar o escopo porém, caso realmente precise mudar os itens do backlog selecionado, ele tem a opção de cancelar o sprint. Neste caso, a iteração volta ao início, para a Sprint Planning 1 (Figura 2.9).

Diariamente durante o sprint, os membros da equipe se reúnem no mesmo horário para fazer a Daily Scrum, uma rápida reunião para sincronizar o trabalho. Cada membro da equipe conta o que fez desde o último encontro, o que pretende fazer até o próximo e quais problemas está tendo. Discussões técnicas ou específicas devem ser tratadas individualmente após a reunião, pois ela não deve durar mais do que 15 minutos. O ScrumMaster atua como facilitador do encontro. O dono do produto e outros clientes envolvidos podem participar apenas como ouvintes pois essas discussões dizem respeito ao trabalho da equipe, que deve ter autonomia e liberdade de tomar decisões para alcançar sua meta.

Quando o sprint termina, a equipe apresenta o trabalho na reunião de revisão do sprint ao dono do produto através de uma demonstração. O dono do produto faz testes para verificar se cada item atende às suas expectativas e determinar se a meta foi atingida. A meta sempre "é atingida" ou "não é atingida". Não existem opções intermediárias. Desta forma a equipe deve se preocupar com a qualidade de tudo que entrega para não colocar em risco o trabalho do sprint inteiro.

Após cada entrega, a equipe realiza uma retrospectiva (Figura 2.9, Retrospective) para avaliar seu trabalho e identificar oportunidades para melhorar seu desempenho nos próximos sprints. O ScrumMaster e os membros da equipe repensam o último sprint e refinam o processo de desenvolvimento através de uma reflexão sobre o passado. O resultado da retrospectiva são três listas: 1) as ações que trouxeram resultados positivos e devem ser mantidas; 2) as ações sem resultado ou problemas que reduziram o rendimento; e, 3) mudanças e novas práticas para usar no próximo sprint e eliminar o que foi apontado na listagem 2. As listas 2 e 3 servem de entrada para o próximo planejamento como pontos a serem considerados.

\subsubsection{Feature Driven Development - FDD}

FDD foi usada pela primeira vez em 1997 por Peter Coad e Jeff De Luca. Dois anos depois, publicaram um livro contando essa experiência [CdLL99]. Mais tarde, Stephen Palmer e John Felsing publicaram uma versão aprimorada e detalhada da metodologia [PF02]. FDD mantém seu foco nas fases de modelagem e implementação, sem a pretensão de cobrir todo o processo de desenvolvimento do software. Por isso, ela pode ser combinada com outras técnicas para a produção de sistemas 
complexos [PF02].

\section{Papéis}

FDD divide os papéis em três grupos: papéis chave, papéis de apoio e opcionais. Dentro de cada categoria os papéis podem ser atribuídos a vários participantes para multiplicar uma função ou compartilhar responsabilidades. Gerente do projeto, arquiteto chefe, gerente de desenvolvimento, programador chefe, dono de classe e o especialista de negócios são os responsáveis pelo desenvolvimento da aplicação, por isso são os papéis chave. Os papéis de apoio ao desenvolvimento são o gerente de versão, o guru de linguagem, o engenheiro de integração e o toolsmith, que é o responsável por criar programas que auxiliem os outros desenvolvedores a construir o produto final. Os papéis opcionais são testadores, implantadores e escritores técnicos.

\section{Processo}

Os processo proposto por FDD consiste de cinco etapas que cobrem as fases de modelagem e implementação do software. As três primeiras são feitas no início do projeto instituindo um planejamento de nível médio, as duas últimas são repetidas iterativamente para construir o planejado. As etapas são:

1. Desenvolver um Modelo Abrangente: Para criar um modelo de alto nível os especialistas do negócio já devem ter estabelecido um consenso sobre os objetivos, o escopo e as funcionalidades do projeto. Como a metodologia não define como obter ou gerenciar os requisitos, as especificações e os casos de uso já devem estar prontos para que a equipe de negócios ofereça explanações de alto nível ao arquiteto chefe e os desenvolvedores para que eles criem um modelo panorâmico do projeto. Em seguida, este modelo é subdividido para que pequenos grupos formados por especialistas de negócio e desenvolvedores abordem cada uma das partes para chegar à modelagem de objetos. Por fim, os objetos são reunidos, revisados e integrados para chegar à versão inicial do modelo de objetos do sistema.

2. Construir a Lista de Funcionalidades: Baseado nas explicações dos especialistas de negócio, nos artefatos da especificação e no modelo de objetos criado na fase anterior, é identificada uma lista de funcionalidades com valor de negócio que compreende todo o escopo do projeto. No fim, clientes e usuários revisam e validam a listagem. 
3. Planejamento por Funcionalidade: Visa a criar um planejamento de alto nível para todo o projeto. Os gerentes e programadores chefes definem a ordem em que as funcionalidades serão implementas baseados no valor de negócios, dependências e volumes de trabalho. As funcionalidades podem ser agrupadas para formar versões potencialmente entregáveis e as classes do modelo atribuídas aos programadores, que passam a ser chamados de donos dessas classes.

4. Modelagem por Funcionalidade: Os programadores chefes selecionam conjuntos de funcionalidades para formar pacotes de trabalho com duração de dois dias a duas semanas. Para cada pacote de funcionalidades, os programadores donos das classes envolvidas são convocados para integrar a equipe. Dessa forma, diversas pequenas equipes trabalham em paralelo sob o comando de um programador chefe. Se preciso o modelo de objetos é refinado para comportar as funcionalidades de cada pacote.

5. Implementação por Funcionalidade: Para cada funcionalidade do pacote, a equipe implementa, testa e inspeciona o código. Quando o programador chefe autoriza, as funcionalidades são integradas ao repositório principal e novos pacote e equipe são formados pelo programador chefe para a próxima iteração.

\section{Práticas}

FDD utiliza oito técnicas conhecidas na indústria como "boas práticas" para o desenvolvimento de sistemas [PF02]. Além das vantagens de cada uma, a força da metodologia está no uso combinado das práticas desse conjunto.

- Modelagem de domínio de objetos: Diagramas classe e de seqüência com os objetos do sistema, mesmo que simplificados, permitem validar possíveis soluções e refinar o entendimento das funcionalidades. A participação da equipe na criação da modelagem de objetos elimina divergências de modelagem e de implementação.

- Desenvolvendo por Funcionalidade: Desenvolver e entregar por funcionalidade garante que o projeto produza o que os clientes desejam, pois o desenvolvimento é guiado pelos requisitos funcionais com valor de negócio e em tamanhos pequenos.

- Propriedade de Classes: Cada classe do sistema possui um programador responsável e cada programador é dono de um grupo de classes. Esta estratégia aumenta o senso de responsabi- 
lidade sobre o código e evita problemas com múltiplos desenvolvedores modificando o mesmo código.

- Equipes por Funcionalidade: As equipes são montadas a partir das funcionalidades escolhidas para cada iteração e os participantes são os donos das classes envolvidas. Como várias equipes podem estar trabalhando em paralelo, a melhor forma de evitar problemas com a alocação dos donos das classes é permitir que a classe mude de dono durante o projeto.

- Inspeções: Alguns estudos concluíram que inspeções aumentam a qualidade do código [Gil88, Jon96, $\mathrm{SBB}^{+}$02]. Além disso, inspeções promovem transferência de conhecimento, estimulam a padronização e inibem a inserção de código de baixa qualidade, pois os desenvolvedores sabem que alguém irá verificá-lo mais tarde.

- Versões com Regularidade: A integração freqüente do código e a construção freqüente de versões estáveis do software permite identificar e resolver rapidamente problemas de integração e fornecer informações seguras quanto à evolução do projeto.

- Gerenciamento de Configurações: Idealmente, o sistema de gerenciamento de configurações deve ser simples. No entanto, conforme as características do projeto, é interessante manter um controle de versão para todos os artefatos do projeto.

- Relatórios de Progresso: É importante acompanhar a evolução do projeto e prover informações em níveis diferentes para cada tipo de envolvido com o projeto através de análises e gráficos.

\subsubsection{Adaptative Software Development - ASD}

Com base na teoria dos sistemas adaptativos complexos [GM94] e apoiado por sua experiência com Radical Software Development [BH94], Jim Highsmith criou o ASD [Hig97, Hig00], um método de desenvolvimento de software que considera a incerteza e a instabilidade dos requisitos e permite que o aprendizado aconteça durante o desenvolvimento.

\section{Fases}

O ASD segue um modelo iterativo com etapas curtas que se sobrepõem. Essa dinâmica, assim como outras metodologias ágeis, permite que a equipe adquira experiência, melhore seu modo de trabalho e colabore para a criação do produto final. As suas três fases são: 
- Especulação - Partindo do princípio que pessoas são incapazes de fazer planos completos e detalhados para situações complexas, especulação é a melhor forma de classificar previsões com alto grau de incerteza. Este rótulo deixa a incerteza em evidência para que fique claro que adaptações estão previstas. Com essa consciência desde o início, torna-se mais fácil realizar mudanças, pois os envolvidos estão cientes das limitações do planejamento e, portanto, mais propícios a aceitá-las.

- Colaboração - Considerando a dificuldade de fazer bons planos para ambientes de alta instabilidade e complexidade, o gerenciamento desses ambientes também torna-se uma tarefa difícil. Para não tornar o processo dependente de um bom gerenciamento, uma parcela da responsabilidade de comando é diluída entre os envolvidos através da colaboração do grupo.

- Aprendizado - Constantemente, programadores e clientes devem rever seus conceitos sobre o produto em desenvolvimento. Ciclos de revisão em períodos curtos favorecem a compreensão dos detalhes e a validação do que foi planejado. Discussões freqüentes sobre o que foi aprendido evitam que grandes erros sejam cometidos ou passem despercebidos por muito tempo.

\subsubsection{Programação eXtrema - XP}

Kent Beck criou XP depois de vários anos de atuação na indústria de desenvolvimento de software. A partir de uma larga experiência com Smaltalk, publicou em 1996 um livro com suas melhores técnicas de programação [Bec96]. No mesmo ano, foi convidado para conduzir um projeto crítico na Chrysler: um sistema para a folha de pagamento que já havia estourado os custos e os prazos sem alcançar resultados substanciais. Com Martin Fowler e Ron Jeffries na equipe, Beck conseguiu tornar a equipe altamente produtiva e entregar um sistema de excelente qualidade começando do zero e terminando o projeto em menos tempo do que havia sido gasto nas tentativas anteriores.

No projeto da Chrysler, Beck selecionou um conjunto de práticas que haviam se mostrado eficientes separadamente em outros projetos e as aplicou juntas e potencializadas [ $\left.\mathrm{ABB}^{+} 98\right]$, com isso cunhou a Programação Extrema. Beck percebeu que revisão de código, testes, integração rápida, feedback do cliente, design simples, entre outras práticas, eram atividades que aumentavam a qualidade do produto. Sua proposta foi intensificar a utilização delas ao extremo, fazendo, por exemplo, revisão constante do código através de programação em pares, intensificando o uso de testes com testes automatizados, antecipando os testes com testes a priori e permitindo um acompanhamento constante do projeto com o cliente presente. 
Em 1999, publicou "Extreme Programming Explained: Embrace Change" [Bec99], o livro que introduziu e tornou a metodologia internacionalmente conhecida. Na conferência OOPSLA do anos seguintes, XP ganhou grande repercussão por trazer idéias opostas aos paradigmas vigentes de desenvolvimento de software. No entanto, XP ainda era uma metodologia destinada exclusivamente a pequenas equipes, de no máximo 12 pessoas. Em 2004, junto com sua esposa, Cynthia Andres, Beck lançou a segunda edição do livro [BA04], tornando XP mais inclusiva, abrangente e flexível através do enfoque nos valores da metodologia.

\section{Valores}

A primeira edição do livro de XP foi baseada em quatro valores que, em alinhamento com o Manifesto Ágil, definiram as prioridades da metodologia. Na segunda edição, o valor do "Respeito" foi incluído para ressaltar o lado humano presente no desenvolvimento de software. Os cinco valores são:

- Comunicação é fundamental para a obtenção de um produto de qualidade que atenda às necessidades do cliente. XP favorece a comunicação entre todos os membros da equipe através de atividades colaborativas. A equipe trabalha pelo mesmo objetivo, produzindo e modificando pedaços de código que se comunicam e refletem no resultado que é entregue ao cliente. Quanto mais intensificada for a comunicação, mais facilmente serão aproveitadas as contribuições de cada membro e tarefas individualizadas poderão contar com a colaboração de outros participantes, fazendo com que críticas tornem-se contribuições que melhoram as soluções antes mesmo de serem implementadas. Os princípios da humanidade e da diversidade preocupam-se em estimular a comunicação principalmente entre os desenvolvedores. Os princípios da economia e do benefício mútuo promovem a colaboração entre participantes com perfil técnico e com o perfil de negócios, que é importante para garantir que os desenvolvedores compreendam os pontos de vista dos usuários e possam produzir soluções adequadas às suas expectativas e necessidades.

- Simplicidade nas soluções para evitar esforços desnecessários. É mais válido gastar pouco esforço para produzir uma solução simples e depois sofisticá-las do que criar de imediato implementações complexas com funcionalidades extras. Funcionalidades e complexidade desnecessárias aumentam a complicação do código e o tornam mais propenso à introdução de erros, exigindo mais horas de programação e mais refatorações. Tudo isso dificulta o crescimento e a manutenção da arquitetura e do código, desviando o projeto de seus principais objetivos e 
atrasando a entrega das funcionalidades essenciais. Os princípios do benefício mútuo, autosemelhança, melhoria e passos pequenos promovem a simplicidade durante o desenvolvimento.

- Coragem é importante para mudar, inovar e aceitar que não se sabe de tudo. À medida que o conhecimento sobre o projeto aumenta, muitas decisões precisam ser revistas e o preço a ser pago é abrir mão de planos e de trabalho feitos no passado para chegar a soluções adequadas à realidade do projeto. Para motivar o surgimento de coragem junto com responsabilidade, os princípios da humanidade e da aceitação da responsabilidade valorizam as pessoas e aumentam as suas auto-confianças e os princípios do benefício mútuo, melhoria e oportunidade sugerem que a equipe se sinta segura e confiante para fazer as mudanças necessárias.

- Feedback constante entre todos os envolvidos permite que a equipe e o projeto identifiquem seus problemas e se adaptem a eles [Ker01]. Quanto mais cedo impedimentos forem encontrados e removidos, menos tempo eles irão atrapalhar. Quanto mais freqüente forem as avaliações, do produto e do processo de desenvolvimento, mais rapidamente serão identificados os problemas e as soluções. Os princípios da humanidade, melhoria, reflexão, fluxo, oportunidade e passos pequenos garantem feedback e melhorias constantes.

- Respeito entre as pessoas é a peça principal para que os demais valores corroborem. Sem respeito, a Comunicação e o Feedback serão pouco eficientes e a Coragem de um membro poderá ser nociva aos demais por não estar alinhada com os interesses da equipe. Todos os participantes devem manter o respeito entre si e em relação aos seus trabalhos. Desvalorizar alguém, a função que exerce ou a qualidade de seu trabalho são formas de falta de respeito que minam a sinergia da equipe. Uma forma de respeito de cada um para com a equipe é assumir responsabilidades que serão capazes de cumprir e da equipe para com seus membros é confiar que cada um fará o melhor trabalho possível. XP considera que os desenvolvedores também são pessoas e preocupa-se com suas necessidades pessoais e profissionais através dos princípios da humanidade e da diversidade, estabelecendo compromissos com o princípio da aceitação da responsabilidade.

\section{Documentação e Material de Apoio}

A documentação em XP é minimalista: em um cenário ideal, apenas o código e os testes a compõem. Um código simples, claro e bem estruturado facilita a compreensão por outros programadores e pelo próprio desenvolvedor no futuro. Com ajuda de comentários relevantes, o código é 
a documentação mais completa e detalhada que um software pode ter, com a vantagem de que ela não se desatualiza e não requer esforços extras com manutenção. Alternativamente, a geração dos documentos a partir do código é uma opção aceitável, porém menos preferível, porque uma vez gerada, essa documentação fica separada do código e, em geral, requer-se algum esforço para mantê-la sincronizada.

Além do código, pouco material é produzido. Apenas cartões de história e radiadores de informação $^{8}$ são recomendados, e mesmo assim, quando não forem mais necessários devem ser descartados [BA04].

Os cartões de história são de papel e servem para os clientes e usuários descreverem as funcionalidades que desejam no sistema. Os programadores os utilizam para guiar o seu trabalho. Cohn sugere um formato para escrita dos cartões [Coh06] (página 136). Cada cartão é escrito a lápis para poder ser modificado no futuro e pode conter outras informações referentes àquela funcionalidade, como por exemplo, o responsável por implementá-lo, estimativas e o número de horas gastas na implementação [BA04]. Sharp e Robinson apresentam dois layouts para cartões de história usados por equipes com experiência em XP [SR07].

Os radiadores de informação são cartazes espalhados pelo ambiente de desenvolvimento que exibem gráficos e dados que destacam pontos importantes do projeto e tornam o ambiente autoinformativo, permitindo que análises simples possam ser facilmente conduzidas a qualquer momento. Dentre as diversas possíveis informações que os radiadores podem exibir, algumas das mais comuns são gráficos com: a evolução do número de testes, a quantidade de cartões concluídos por iteração, a qualidade do código medida a partir da opinião dos desenvolvedores, entre outras.

\section{Papéis}

Uma equipe de XP deve reunir todas as habilidades técnicas e de negócios para produzir o software. A hierarquia entre os desenvolvedores deve ser rasa e sem necessariamente uma divisão preestabelecida de tarefas. Em princípio, as responsabilidades são atribuídas de acordo com especialidades, mas ao longo do tempo, espera-se que essas especialidades sejam disseminadas entre os envolvidos para evitar a concentração de conhecimento e estimular o crescimento profissional de todos os participantes.

\footnotetext{
${ }^{8}$ Radiador de Informação foi um termo definido por Cockburn [Coc06], mais detalhes podem ser encontrados na página 67.
} 
Kent Beck descreve papéis importantes dentro de uma equipe, porém nem todos precisam coexistir, ou necessariamente precisam ser atribuídos a pessoas diferentes [BA04]. Uma equipe completa de XP prevê papéis para programadores responsáveis por estimar, implementar e testar; analistas de negócios que auxiliam o cliente a definir histórias; analistas de testes que identificam cenários de teste; projetistas de interação que avaliam a utilização do sistema pelos usuários; arquitetos que analisam a estrutura do sistema para identificar melhorias de grande impacto; gerentes de projeto que promovem a comunicação e removem os impedimentos que dificultam o trabalho dos programadores; gerentes de produto que escrevem e priorizam histórias e definem os objetivos dos ciclos do projeto; redatores técnicos que produzem a documentação para os usuários finais; executivos que preocupam-se com objetivos de alto nível; recursos humanos que resolvem problemas burocráticos; e, usuários que contribuem com opiniões, sugestões e críticas para ajustes e novas histórias.

Entre os programadores, os papéis de coach e tracker são atribuídos e opcionalmente podem fazer um rodízio pelos membros da equipe durante o projeto para que os envolvidos exercitem outras habilidades além da programação.

Coach: Geralmente um programador experiente da equipe. Kent Beck define o coach como a "consciência do time" [Bec99]. Ele é responsável por verificar se os outros programadores estão realizando as práticas propostas e assegurar que a metodologia seja seguida.

Tracker: Ron Jeffries define o tracker como um desenvolvedor responsável por prover informações sobre o progresso do projeto através de métricas apropriadas e por mostrar pontos a melhorar [JAH00]. O tracker exibe essas informações através de gráficos e pôsteres espalhados pelas paredes do ambiente de trabalho. É função do tracker escolher quais deles mais ajudarão a equipe em cada momento do projeto. Sato apresenta um catálogo de métricas para o tracker de XP e formas eficazes de fazer o acompanhamento de projetos [Sat07].

O papel do cliente é assumido por aqueles que possuem conhecimento das regras de negócio, que sabem ou conseguem definir as prioridades funcionais do software. Apesar de não participarem da codificação, os clientes devem estar junto com os programadores no ambiente de desenvolvimento para esclarecer dúvidas dos programadores, fornecer feedback sobre o que já foi desenvolvido e ajudar na construção de testes automatizados ou na definição de seus cenários. Quando o cliente não puder estar presente o tempo todo, o coach pode representá-lo, assumindo o papel de cliente proxy [Wue02, WBA02]. 


\section{Fases}

Um projeto com XP começa com a fase de Exploração que, dependendo da complexidade e das restrições do projeto, pode consumir desde poucos dias até algumas semanas. Os programadores começam o projeto tendo contato direto com o cliente para conhecer suas necessidades e intenções. À medida que a equipe de desenvolvimento adquire conhecimento sobre o produto, ela pesquisa e discute as tecnologias, arcabouços e ferramentas capazes de prover a solução mais adequada considerando as funcionalidades e os critérios de desempenho, confiabilidade, segurança, portabilidade, escalabilidade, manutenção, custo e tempo indicados pelo cliente. A fase de exploração é marcada por muita pesquisa e leitura. Para auxiliar na tomada das decisões, a equipe de desenvolvimento pode produzir pequenas aplicações, que Kent Beck chama de "spikes" [BA04], para avaliar com mais precisão as tecnologias em questão e assim comparar seus resultados. Essas aplicações são feitas sem a pretensão de que possam fazer parte do produto final. Elas são descartadas quando a implementação do software se inicia, no entanto serviram para familiarizar a equipe com tecnologias novas ou desconhecidas.

Para fazer o Planejamento, a equipe de negócios descreve as funcionalidades que precisa nos cartões de história, acompanhada pela equipe de desenvolvimento, que pode tirar dúvidas e sugerir adaptações ou melhorias com base em seu conhecimento técnico. Com tecnologias e ferramentas escolhidas, os programadores estimam o volume de trabalho de cada funcionalidade e anotam no próprio cartão de história.

Todo o processo de escrita de cartões, priorização e estimativas faz parte do Jogo do Planejamento [BF01]. Através desses elementos a equipe fará o planejamento das versões (releases) do produto agrupando os cartões de acordo com funcionalidades que fazem sentido serem entregues juntas para os usuários. Em seguida, a equipe faz o planejamento das iterações, dividindo os cartões da primeira versão em grupos menores: as iterações.

O foco do planejamento das versões é orientar as expectativas de negócio em relação à obtenção de versões que entrem em produção. Conforme a estratégia da equipe de negócios, duas abordagens podem ser usadas para defini-las:

- Se existe um conjunto mínimo de funcionalidades estritamente necessário para compor a versão, o escopo da versão está fixado e as estimativas desses cartões podem ser usadas para calcular o tempo de implementação.

- Se fatores ou eventos externos ao projeto definem uma data, o tempo para entrega da versão 
está prefixado. Neste caso, a partir das prioridades mais altas, as estimativas são usadas para escolher o escopo, isto é, quais funcionalidades serão implementadas no período determinado.

O que comumente acontece na indústria são restrições de tempo associadas à necessidade de um escopo além do que as estimativas indicam. Uma opção para este caso é o aumento da equipe, porém a velocidade de desenvolvimento não está simplesmente associada ao número de pessoas que a compõe. O tempo de aprendizado, a instabilidade dos requisitos e a complexidade para integração do código são fatores que desviam o tempo de desenvolvimento da linearidade. Seguir em frente ignorando grandes incompatibilidades entre tempo e escopo pode significar fracasso ou falta de qualidade.

O planejamento das iterações estabelece pontos de controle dentro da versão para programadores e clientes saibam como a execução está em relação ao planejado. No planejamento da iteração, os programadores analisam novamente cada cartão, desta vez para identificar as tarefas de implementação associadas a ele e para se comprometerem individualmente com a implementação. Opcionalmente cada desenvolvedor pode fazer estimativas das tarefas que identificou em cada cartão.

A fase de Implementação inicia com os programadores focados em concluir a iteração. Durante a implementação, a equipe realiza as práticas descritas na seção seguinte. No fim da iteração, os clientes aprovam a implementação dos cartões ou não, através de testes funcionais. O planejamento da próxima iteração começa considerando o planejamento feito para a versão e verifica se há mudanças consideráveis nas funcionalidades ou se novos fatores impactam na velocidade de desenvolvimento.

\section{Princípios}

Na segunda edição do livro, quatorze princípios foram introduzidos na metodologia [BA04]. Eles funcionam como ferramentas ou canais mentais para transformar os valores, que são abstratos, em práticas de fácil implementação no desenvolvimento.

- Humanidade: A produção do software depende dos desenvolvedores. É importante levar em conta que os desenvolvedores são pessoas com necessidades individuais que devem ser respeitadas e balanceadas com os interesses de negócio e as necessidades da equipe.

- Economia: A equipe deve possuir consciência das necessidades de negócio e eleger as prioridades para agregar o máximo de valor no menor intervalo de tempo. Ter flexibilidade para reagir rapidamente a mudanças também é importante pois facilita a reeleição de prioridades. 
- Benefício mútuo: As atividades executadas devem sempre trazer benefícios para os envolvidos. Testes, refatorações e metáforas são exemplos de atividades que trazem ganhos imediatos pois aumentam a compreensão e a confiabilidade do software. Por outro lado, documentos extensos e planejamentos detalhados de longo prazo não trazem benefício imediato e estão altamente sujeitos a mudanças no futuro.

- Auto-semelhança: Boas soluções devem poder ser aplicadas novamente, inclusive em outros contextos e escalas. A idéia é identificar estruturas equivalentes a padrões de projeto [GHJV95, $\mathrm{BMR}^{+96]}$ para o processo de desenvolvimento.

- Melhoria: É necessário implementar melhorias constantemente, contudo mais importante é difereciar o "bom" do "ótimo". A equipe pode produzir algo "bom" para colocar em produção rapidamente (satisfazendo o princípio da economia) e, em um segundo momento, com um pouco mais de esforço, aprimorá-lo para chegar ao "ótimo".

- Diversidade: A equipe deve reunir muitas habilidades, opiniões e perspectivas pois assim o universo de idéias e soluções cresce. Junto com a diversidade, é importante que a equipe possua o valor do respeito, pois ele garante que as diferenças colaborem para o crescimento de todos.

- Reflexão: Constantemente a equipe deve repensar o que fez, assim poderá avaliar suas decisões e aprender com o passado, identificando pontos a melhorar e experiências de sucesso que podem ser repetidas.

- Fluxo: O processo de desenvolvimento deve ser constante em relação ao ritmo de trabalho e à quantidade de software entregue. A equipe deve sempre ser capaz de fazer a integração do código e a implantação de novas versões em períodos tão curtos quanto for possível. Desta maneira, o risco e o tamanho de possíveis defeitos é minimizado e o custo para corrigi-los sempre será pequeno.

- Oportunidade: A equipe deve estar sempre disposta a melhorar e atenta às oportunidades que surgem. Mudanças inesperadas e problemas devem ser vistos como oportunidades para aprendizado e melhoria.

- Redundância: Devemos acrescentar meios para assegurar a qualidade do software, reduzindo a chance de erros. Através de testes automatizados e programação em pares diminuímos a probabilidade de defeitos e aumentamos a confiança da equipe em seu trabalho. 
- Falha: A equipe deve ter coragem para tentar opções alternativas quando elas surgirem, mesmo sabendo que algumas irão falhar. No entanto, o mais importante é aproveitar a experiência para adquirir algum aprendizado e estar disposto a abandoná-las para investir o esforço, desta vez com mais experiência, em uma opção melhor.

- Qualidade: XP não considera a qualidade como um fator negociável junto com escopo e tempo. A qualidade deve ser uma meta constante para a equipe. O aumento da qualidade do código trará mais motivação para a equipe, mais satisfação para o cliente e maior velocidade para novas implementações.

- Passos pequenos: A equipe deve fazer desenvolvimento dirigido por testes, integração do código e a implantação de novas versões em etapas com tamanho pequeno o suficiente para ter certeza de que está no caminho certo. Desta forma, o risco e o tamanho de possíveis erros é minimizado e o custo para corrigi-los também será menor.

- Aceitação da responsabilidade: Cada membro da equipe deve aceitar suas responsabilidades. Quando os programadores se responsabilizam pelas estimativas, pela implementação e pelos testes assumem compromissos pessoais com a entrega que tornam o trabalho mais motivante e recompensador.

\section{Práticas}

Na primeira versão do livro de Kent Beck foram propostas 12 práticas que traduzem os valores em ações para serem executadas no dia-a-dia do trabalho. São elas:

1. Versões Pequenas: A equipe deve implementar e entregar freqüentemente pequenas partes de software funcionando. O tamanho da iteração deve ser constante durante o projeto e de, no máximo, três semanas cada uma para que o cliente forneça feedback constante e a equipe consiga ter uma visão precisa do andamento do projeto sem surpresas no final.

2. Jogo do Planejamento: No começo do projeto, os clientes escrevem cartões com histórias que descrevem os requisitos do sistema. Programadores e clientes colaboram para selecionar o subconjunto de cartões com maior valor agregado: os programadores fornecem estimativas para cada história enquanto os clientes definem os seus valores de negócio. O planejamento acontece 
em dois níveis: no começo da implementação de cada release ${ }^{9}$ e no começo de cada iteração. Uma release é composta de várias iterações. No final de cada iteração um subconjunto das histórias da release devem ter sido implementadas. A decisão feita neste ponto é apenas um plano inicial: mudanças são bem vindas e podem ser incorporadas ao plano durante o projeto. Contudo, é importante que a equipe esteja disposta a fazer adaptações neste plano.

3. Design Simples: Simplicidade é o conceito chave que permite que um sistema adapte-se a mudanças. Para minimizar o custo das mudanças, deve ser implementado o design mais simples, com o nível de complexidade e flexibilidade necessários para atender às necessidades do momento. Como o desenvolvimento é incremental, os programadores não devem tentar antecipar requisitos, pois serão adicionados mais tarde se forem realmente necessários e o design será naturalmente melhorado através de refatorações. Funcionalidades extras ou flexibilidade desnecessária irão atrasar o cumprimento de tarefas essenciais e aumentarão a complexidade do sistema, dificultando a inclusão das próximas funcionalidades. Um dos lemas de XP é: "Faça o mais simples que possa funcionar."

4. Programação em Pares: Desenvolvedores trabalham em pares durante as tarefas de implementação para promover o trabalho coletivo e colaborativo. As duplas são trocadas freqüentemente para que todos os participantes tenham a possibilidade de interagir, aumentando a comunicação e a união do grupo. Com duas pessoas concentradas na mesma tarefa, a inserção de muitos erros é evitada e quando existem, eles são encontrados mais rapidamente. Enquanto um dos programadores digita, o outro revisa o código e sugere melhorias. Com o tempo, o trabalho em duplas promove a replicação de conhecimentos específicos de cada participante em vários membros da equipe. A seleção dos pares geralmente depende da tarefa, da disponibilidade dos programadores e da experiência de cada um.

5. Testes: O software é constantemente exercitado por um conjunto de testes automatizados escritos por programadores e clientes. A equipe de programadores escreve testes de unidade para todos os componentes do sistema e os executa várias vezes ao dia para assegurar que funcionalidades adicionadas recentemente não tenham introduzido erros no código antigo. Os clientes escrevem testes de aceitação para assegurar que o sistema faça exatamente o que eles solicitaram. Estes testes são executados sempre que uma nova funcionalidade é implementada para determinar se o cartão de história realmente está concluído. Esses testes podem ser

\footnotetext{
${ }^{9}$ Versão entregue do software.
} 
escritos por pares formados por clientes e programadores quando os clientes não possuírem conhecimento técnico para fazê-lo.

6. Refatorações: São um conjunto de técnicas sistemáticas para reorganizar o código, alterando sua estrutura interna sem modificar o comportamento externo [FBB $\left.{ }^{+} 99\right]$. As refatorações podem variar de simples mudanças de nomes de variáveis, métodos ou classes para tornar o código mais inteligível, passando pela remoção de código duplicado, até a simplificação da arquitetura do sistema $\left[\mathrm{FBB}^{+} 99\right.$, Ker04]. Os objetivos sempre são tornar o código mais legível, simples, organizado e preparado para acomodar novas funcionalidades.

7. Integração Contínua: O código fonte deve ser mantido em um repositório comum a toda a equipe de forma que sempre que alguma tarefa é concluída, o novo código possa ser executado, testado, e, se correto, integrado no repositório. Os programadores incluem e recuperam código do repositório várias vezes ao dia, assim todos os membros da equipe mantêm-se sincronizados, trabalhando com a versão mais recente do código.

8. Propriedade Coletiva do Código: Não existe o conceito de propriedade exclusiva ou restrita do código. O código do repositório é a última versão estável do sistema e é propriedade de toda a equipe. Se uma dupla de programadores precisar modificar um trecho do código ou identificar oportunidades para refatorá-lo, eles podem, e devem, fazê-lo sem pedir permissão a quem o escreveu originalmente. Esta dupla também deve verificar a validade das mudanças escrevendo novos testes e fazendo com que todos os testes passem, inclusive os que já existiam, para depois criar uma nova versão estável do código.

9. Ritmo Sustentável: O ritmo de trabalho não deve afetar a saúde ou a vida pessoal dos participantes. Durante o planejamento, a quantidade de horas de trabalho dedicadas ao projeto deve ser definida realisticamente. É aceitável que a equipe trabalhe horas extras em situações raras. Uma extensiva e recorrente sobrecarga de trabalho irá reduzir a qualidade do código e trará perdas no médio e longo prazo.

10. Cliente Presente: A equipe deve ser composta por diferentes pessoas com amplo conhecimento e experiência de forma a preencher todas as habilidades necessárias para o projeto. Isto deve incluir pessoal da área de negócios, chamados de clientes, que entendem as necessidades dos usuários e possuem conhecimento sobre as regras de negócio do sistema. O cliente escreve histórias, define prioridades, responde dúvidas dos programadores e acompanha a implantação, se possível, diariamente. 
11. Metáfora: Os participantes do projeto devem encontrar uma linguagem comum para falar sobre o sistema, relacionando suas abstrações com elementos do mundo real. Esta linguagem deve ser igualmente entendida por pessoas da área técnica e por pessoas da área de negócios para facilitar a comunicação entre eles. Esta provavelmente é a prática mais difícil de introduzir em uma equipe inexperiente porque ela está diretamente relacionada à comunicação e a quão compreensíveis as pessoas serão ao compartilharem seus desejos, idéias e conhecimentos.

12. Padrões de Código: Antes de começar a programação, os programadores devem definir um conjunto de padrões para ser usado na escrita do código. Isso torna o código mais fácil de entender, melhora a comunicação, facilita refatorações e contribui para a Propriedade Coletiva.

Depois de algum tempo, adeptos de XP perceberam que simplesmente aplicar todas as práticas, sem considerar os princípios e valores por trás delas não era uma abordagem efetiva. O que faz sentido, de acordo com a própria filosofia que XP segue: métodos ágeis devem ser adaptativos e não-prescritivos. Esta observação levou à criação de uma nova prática, chamada "Conserte XP quando ela não funciona", que sugere que quando não for possível aplicar XP em sua totalidade, as práticas devem ser adaptadas de acordo com o ambiente. Desta forma, as práticas de XP não devem ser vistas como dogmas, mas como orientações para organizar o comportamento da equipe e como base para reflexão contínua.

\section{Práticas Reformuladas}

Seguindo a prática que recomenda a adaptação da metodologia, a segunda versão de XP torna a aplicação das práticas mais flexível quebrando as doze práticas originais em treze práticas primárias e onze práticas corolárias, que juntas traduzem a filosofia e os princípios da metodologia.

As Práticas Primárias são úteis independentemente do contexto do projeto e especialmente adequadas para a introdução da metodologia. Das treze práticas primárias, duas pertenciam às doze práticas propostas inicialmente, a integração contínua e a programação em pares. Outras duas sofreram mudanças de nome: a antiga ritmo sustentável passou a ser chamada de trabalho energizado e a testes automatizados passou a se chamar desenvolvimento dirigido por testes. As outras nove são:

- Sentar Junto: A equipe deve possuir um ambiente comum para atividades de programação em dupla e de planejamento em grupo. A proximidade entre as pessoas irá contribuir para 
identificar e valorizar as habilidades individuais. A intensificação da comunicação favorecerá a colaboração, a ajuda mútua e a disseminação do conhecimento.

- Time Completo: A equipe deve ser constituída por pessoas que reúnam todas as habilidades técnicas e analíticas necessárias para conduzir o projeto ao sucesso. Faz parte do processo de análise e planejamento identificar essas habilidades para reunir profissionais com espírito de equipe que as atendam e queiram trabalhar de forma colaborativa.

- Área de Trabalho Informativa: O ambiente de trabalho deve fornecer informações sobre o andamento do projeto e permitir uma comunicação fácil e sem barreiras. Desenvolvedores e clientes devem trabalhar em um local com acesso fácil a dados do projeto e às métricas mantidas pelo tracker, pois a visibilidade dessas informações permite que a equipe identifique questões relevantes e tome decisões rapidamente.

- Histórias: As funcionalidades são brevemente descritas pelo cliente em cartões de papel que podem ser manuseados facilmente, por ele próprio e pelos desenvolvedores. Os programadores anotam suas estimativas de quantidade de trabalho em cada cartão para que sejam usadas durante as reuniões de planejamento para definir prioridades. As prioridades, programador responsável e outras informações relevantes também são anotadas no cartão. Geralmente observações a implementação, tais como o número de horas trabalhadas e quem as realizou, são anotadas no verso dos cartões ${ }^{10}$.

- Ciclo Semanal: O desenvolvimento acontece iterativamente em ciclos curtos nos quais a equipe realiza atividades de planejamento detalhado de curto prazo, com estimativas e priorizações, focados nas histórias que serão implementadas durante a iteração. A cada ciclo a equipe pode utilizar seu desempenho na iteração anterior para fazer um planejamento adequado à sua velocidade.

- Ciclo Trimestral: Em ciclos com duração de alguns meses ${ }^{11}$, releases são produzidas. Elas representam um nível de planejamento que visa a produzir versões entregáveis do software através do trabalho de várias iterações. No planejamento da release, a equipe escolhe um ou

\footnotetext{
${ }^{10}$ Em nossas experiências temos usado cartões de 101,6 x $152,4 \mathrm{~mm}$, com gramatura de $180 \mathrm{~g} / \mathrm{m}^{2}$. Estas dimensões mostraram-se adequadas para comportar descrições e anotações, porém cartões de outras dimensões também atendem ao mesmo propósito.

${ }^{11}$ Os ciclos não precisam ser necessariamente de 3 meses: este é um período razoável para obter avanços representativos. No entanto, as demandas de negócio e as características do projeto devem determinar o tamanho ideal da release.
} 
mais temas do contexto do projeto para serem atacados e os explora com um nível mediano de detalhes. A equipe também aproveita para refletir sobre o ciclo anterior para identificar as principais barreiras e dificuldades para propor soluções e melhorias.

- Folga: Durante o planejamento, deve ser considerada a imprecisão associada às estimativas, pois elas não são nada mais do que previsões. A introdução da folga no formato de tarefas que possam ser descartadas caso seja preciso representa um grau de liberdade para assegurar que todas as tarefas principais sejam realizadas. Com a folga os desenvolvedores ficam mais confortáveis para assumir o compromissos e o cliente tem segurança sobre o mínimo de software que será entregue no fim do ciclo.

- Build Ágil: O build constitui a execução automatizada dos testes e demais tarefas necessárias para verificar a consistência do código e colocar o software em funcionamento. Ele deve poder ser feito rapidamente, em não mais do que 10 minutos. Assim, a equipe consegue realizar ciclos de desenvolvimento e testes constantemente. Quanto menor for o tempo de build, mais vezes ele será executado e mais freqüente será o feedback para a equipe sobre o desenvolvimento e integração de código novo.

- Design Incremental: O design do sistema deve receber a medida certa de sofisticação para suportar as demandas de negócio e manter-se flexível para evoluir sem agregar complexidade antecipada ou despender esforços excessivos para construí-lo. Este conceito permite mitigar os esforços e o custo das mudanças que acontecerão durante a construção do sistema. Criar designs que cresçam incrementalmente não é uma tarefa simples, por isso ela é apoiada por ciclos curtos de desenvolvimento com testes automatizados e refatorações.

As onze Práticas Corolário são de aplicação mais difícil sem experiência com as práticas primárias, pois são mais específicas. Destas, apenas a código compartilhado é a equivalente à antiga propriedade coletiva do código. As outras dez são:

- Envolvimento Real com o Cliente: Esta prática é a evolução da prática cliente presente. A nova abordagem considera que o cliente deve, além de oferecer suporte à equipe técnica, manter o comprometimento com suas responsabilidades de negócio, através da priorização de tarefas e identificação das necessidades dos usuários. 
- Implantação incremental: Esta prática diz respeito principalmente ao desenvolvimento de sistemas que substituem sistemas legados. A transição deve ser gradual, provavelmente ao custo de esforço extra, mas necessário para realizar uma migração segura e suave.

- Continuidade da Equipe: Equipes conquistam resultados graças ao talento das pessoas e à sinergia entre elas. Parte do mérito por resultados positivos é devido a bons níveis de comunicação e colaboração, portanto mudanças nas equipes dificultam a criação de sinergia e deixam o sucesso depender apenas de habilidades individuais. Realocações freqüentes para aproveitar pequenos períodos de disponibilidade das pessoas podem prejudicar os resultados de médio e longo prazo.

- Redução da Equipe: À medida que a equipe melhora seu ritmo de produção ou quando o sistema entra em fase de manutenção, ela pode tornar-se grande demais para o volume de trabalho. Quando isto acontecer, a carga de trabalho de um dos membros pode ser diminuída até que ele fique completamente liberado para outras atividades fora da equipe. Esta estratégia tende a não mascarar ociosidade e é baseada no princípio da eliminação do desperdício do modelo Lean (página 72).

- Análise da Causa Inicial: Para cada defeito encontrado, ele e suas causas devem ser corrigidos. Tão importante quanto corrigir o defeito, é identificar o que o causou para evitar que ele ou outros com a mesma origem apareçam novamente. A estratégia sugerida para tratar defeitos é escrever um ou mais testes de aceitação automatizados que reproduzam o problema; escrever testes de unidade que capturem o defeito no menor escopo possível; implementar as devidas correções de forma que todos os testes passem; analisar porque o problema não foi percebido antes; analisar por que ele foi criado; e tomar atitudes para evitar que novos defeitos aconteçam e/ou que sejam evidenciados quando acontecerem.

- Código e Testes: Apenas o código e os testes automatizados devem ser os artefatos mantidos pela equipe. Documentação que se desatualiza ou gera dependência significa esforço duplicado, portanto é desperdício. Até mesmo cartões de história devem ser descartados quando deixam de ser necessários, assim evita-se investir esforço sem acrescentar valor ao sistema.

- Repositório de Código Unificado: Em reforço e complemento à prática do código compartilhado, é recomendável que exista apenas um repositório de código, preferencialmente sem ramificações. Vários repositórios ou ramificações exigem esforços para manter diversas versões do código. Se existirem ramificações, suas existências devem ser constantemente repensadas. 
- Implantação Diária: Quando a equipe consegue produzir testes com eficiência, realizar build ágil e manter o código integrado, ela pode ser radical com a idéia de releases pequenas, fazendo entregas diárias através de ferramentas automatizadas de deployment. Quando a equipe coloca versões em produção diariamente, a velocidade e a quantidade do feedback aumentará, permitindo que ela reaja com mais velocidade.

- Contrato de Escopo Negociável: Como o cliente pode mudar suas prioridades de negócio, os contratos para produção de sistemas devem fixar a qualidade, o tempo e o custo, deixando o escopo variável para ser definido à medida que o desenvolvimento evolui. Dessa forma, ao invés de ficarem determinadas de antemão todas as funcionalidades e características que o sistema deve possuir, elas podem ser escolhidas à medida que as prioridades de negócios mudam e a equipe ganha domínio das regras de negócio. Este modelo permite que estimativas sejam mais precisas e a implementação cubra sempre as funcionalidades de mais alta prioridade.

- Pague-pelo-uso: Esta prática sugere que a equipe seja paga de acordo com o uso do software. Este modelo de negócios alinha os interesses do cliente e da equipe de desenvolvimento. Neste formato, tanto cliente quanto desenvolvedores têm interesse em ter o maior número de funcionalidades o mais rápido possível em produção, eliminando divergências de escopo e custo tradicionalmente encontradas durante negociações contratuais.

\subsubsection{Família Crystal}

Alistair Cockburn, criador dos métodos Crystal, defende o valor da comunicação e das interações entre as pessoas durante o desenvolvimento de software [Coc00, Coc06], pois com mais comunicação, o número de artefatos intermediários para a obtenção do produto final poderá ser diminuído e o trabalho será mais objetivo [Coc04]. Cockburn também diz que projetos de desenvolvimento de software possuem diferentes características e criticidades, portanto, exigem a adoção de metodologias com pesos adequados à sua complexidade [Coc00]. Para lidar com projetos classificados como simples, ou até projetos críticos, ele estabeleceu um conjunto de métodos, a Família Crystal [Coc06], que compartilham características em comum, mas com diferentes graus de sofisticação e formalismo para serem usados conforme a complexidade de cada projeto.

Os métodos Crystal são focados nos talentos e nas habilidades das pessoas, por isso permitem que o processo de desenvolvimento seja moldado conforme as características específicas da equipe, mesclando a sua cultura de trabalho com a proposta de desenvolvimento ágil. Cada método Crystal é 
caracterizado por uma cor de acordo com o número de envolvidos. Crystal Clear é uma metodologia leve, para equipes de 1 a 8 pessoas, podendo chegar até 12 em casos especiais [Coc04], Yellow, para equipes por volta de 10 a 20 membros, Orange [Coc98, Coc06] e a variante Orange Web [Coc06] são apropriados para times de 20 a 50 participantes e Red para equipes de 50 a 100 membros. Cada um dos métodos com graus de gerenciamento e de comunicação adequados ao tamanho da equipe.

Apesar de nomeá-los, Alistair não definiu todos os métodos. Até o momento apresentou apenas aqueles que lhe foram necessários durante a sua vida profissional, o Crystal Clear, Orange e Orange Web. Yellow e Red ainda não têm muitos detalhes definidos além do tamanho da equipe. Para projetos maiores ou mais críticos, Cockburn prevê a expansão da família com os métodos Maroon, Blue e Violet [Coc04].

Os métodos Crystal apóiam-se em um conjunto comum de princípios que estão alinhados com o Manifesto Ágil $\left[\mathrm{BBvB}^{+} 01\right]$ valorizando o desenvolvimento incremental, entregas freqüentes, envolvimento de usuários e clientes, testes automatizados, adaptação a mudanças e aprendizado contínuo. As equipes focam na produção do software e para isso produzem o menor número possível de artefatos intermediários. Cada equipe tem liberdade para escolher os artefatos que julga úteis para concentrar seus esforços na criação do produto final, o software.

\section{Classificação de Projetos}

Para a escolha da metodologia de trabalho, Cockburn recomenda primeiro classificar o projeto usando duas características: a sua criticalidade e o número de pessoas envolvidas. O número de pessoas é importante porque influencia os meios de comunicação necessários para garantir um nível satisfatório de informação no projeto, pois quanto mais pessoas envolvidas, mais artefatos e formalismo torna-se necessário. A criticalidade é definida pelo tipo de perda causada se um defeito se manifestar no software [Coc00]. Na Figura 2.10 essas variáveis são dispostas em eixos permitindo que os projetos sejam classificados.

Crystal se propõe a lidar com projetos que envolvam desde perdas de conforto até projetos de criticalidade média-alta, que podem provocar grande prejuízo financeiro, sem se ater a projetos que envolvam perdas de vidas. Na tabela da Figura 2.11, adaptada de [Coc06] com a abordagem mais recentemente apresentada em [Coc04], podemos ver para quais tipos de projeto cada metodologia se aplica. 


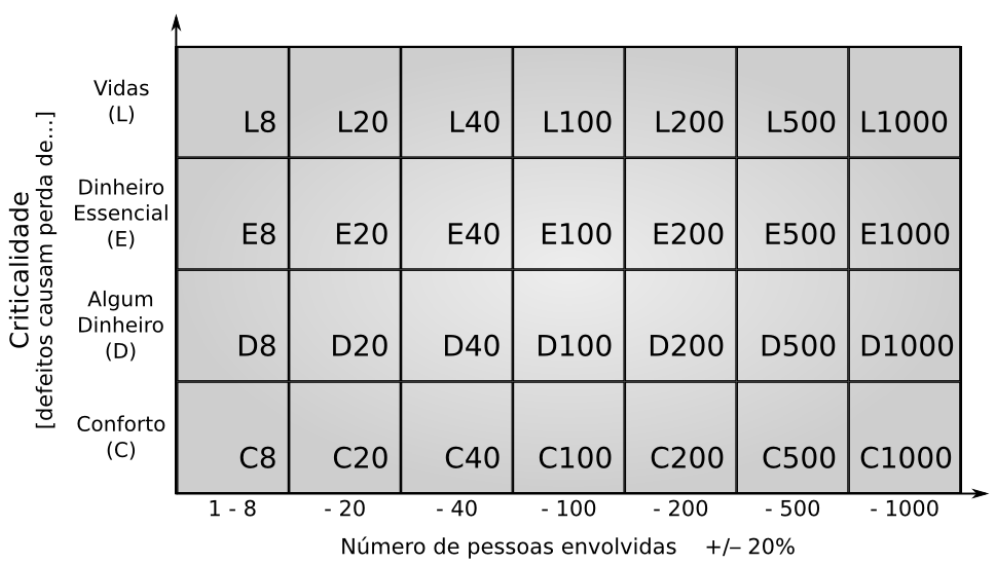

Figura 2.10: Classificação de projetos pela criticalidade e número de envolvidos.

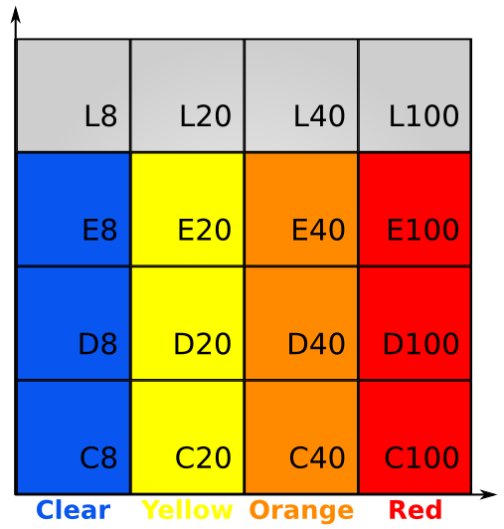

Figura 2.11: Aplicação de metodologias Crystal conforme o número de envolvidos.

\section{Propriedades}

Os métodos Crystal apoiam-se em um conjunto de sete propriedades alinhadas com os valores do Manifesto Ágil $\left[\mathrm{BBvB}^{+} 01\right]$. Dentre eles, três caracterizam-se como principais: Entregas Freqüentes, Comunicação Intensa e Melhora por Reflexão. As propriedades definem os valores da metodologia que devem ser seguidos durante o desenvolvimento. No entanto, para cada método, as propriedades são aplicadas de acordo com as características e o escopo que o projeto se propõe a cobrir. Na página 66 apresentamos as estratégias sugeridas pela metodologia para valorizar essas propriedades. 
1. Entregas Freqüentes - software testado e funcional deve ser entregue a cada poucos meses. As iterações devem seguir o conceito de "time boxing", com datas de entrega fixadas inicialmente.

2. Melhora por Reflexão - a partir de oficinas de reflexão (reflection workshops) ${ }^{12}$ a equipe deve identificar formas de melhorar a metodologia para torná-la mais aderente ao seu contexto e mais eficaz.

3. Comunicação Intensa - como as metodologias são focadas nas pessoas, a comunicação entre elas é um fator importante. Crystal prioriza a comunicação pessoal em detrimento de documentações formais. O ambiente de desenvolvimento deve facilitar a comunicação direta. Quanto menos paredes entre os participantes do desenvolvimento melhor. A equipe deve trabalhar no mesmo ambiente ou em salas próximas, mas nunca em prédios diferentes.

4. Segurança Pessoal - as pessoas devem se sentir à vontade para dar opiniões no trabalho da equipe. É preciso estabelecer um ambiente de confiança dentro da equipe para que as pessoas não tenham medo de admitir atrasos e falta de conhecimento, ou apontar erros e fazer ou receber críticas, pois quanto mais cedo esses problemas forem levantados, mais rápido poderão ser tratados.

5. Foco - as prioridades do projeto devem estar claras. O dono do projeto deve definir claramente as prioridades mais altas para a equipe focar seu trabalho e produzir algo que acrescente valor ao projeto. Para assegurar o foco, os desenvolvedores devem poder trabalhar com o mínimo possível de interrupções externas e de tarefas paralelas.

6. Acesso Fácil a Usuários Experientes - usuários com experiências reais devem ser consultados desde o planejamento para orientar os interesses dos especialistas de negócio a identificar os principais grupos de foco. Durante a implementação, os usuários devem estar disponíveis para esclarecer dúvidas dos desenvolvedores e, após a entrega, para avaliar as funcionalidades.

7. Integração Contínua com Testes - o desenvolvimento deve ser assegurado por testes automatizados e deve permitir que os programadores contribuam e obtenham contribuições facilmente através de integração contínua.

O Crystal Clear usa ciclos de entrega de no máximo 3 meses, o Orange permite ciclos de até 4 meses, enquanto que o Orange Web sugere ciclos de 2 a 4 semanas. Enquanto Crystal Clear exige

\footnotetext{
${ }^{12}$ Reflection Workshop é o nome original que Alistair Cockburn deu para a prática que depois passou a ser conhecida também em outras metodologias com o nome de Retrospectiva.
} 
que a equipe trabalhe no mesmo ambiente e extremamente próxima para realizar a comunicação

osmótica $^{13}$ [Coc04], Crystal Orange, permite que a equipe se divida, pois lida com grupos maiores e a comunicação osmótica entre toda a equipe torna-se difícil. A estratégia neste caso é dividir a equipe em subgrupos formados por membros com habilidades variadas e complementares. Cada subequipe é formada por um analista de negócios, um designer de interface, de 1 a 3 programadores e opcionalmente um analista de banco de dados e um testador. Assim, cada grupo poderá realizar comunicação osmótica internamente e deve manter contato constante com os demais subgrupos, que estão trabalhando próximos, preferencialmente no mesmo andar, mas nunca em prédios diferentes. Crystal Orange baseia-se fortemente na comunicação e não oferece suporte para desenvolvimento com equipes distribuídas.

\section{Papéis}

Dentro da Família Crystal cada método define um grupo de possíveis papéis assumidos por seus membros. Para o Crystal Clear, o patrocinador, o usuário representante, o líder de projeto e o programador são papéis principais que são normalmente assumidos por pessoas distintas. Os papéis de coordenador, o especialista de negócios, o testador e o escritor são secundários e podem ser acumulados ou rotacionados entre os participantes do projeto. Para equipes maiores, Crystal Orange oferece mais papéis: o designer de interfaces gráficas, o projetista de banco de dados, o especialista em uso, o facilitador técnico, o analista de negócios, o arquiteto, o mentor e o reuse point.

O reuse point é um papel de tempo parcial que pode ser assumido por um programador ou arquiteto. A função do reuse point é identificar trechos de código reutilizáveis ou componentes prontos que possam ser usados no projeto. Além disso, ele também pode procurar por oportunidades de refatoração ou de aplicação de padrões de projeto [GHJV95]. O especialista de negócios interage diretamente com os usuários para definir os requisitos funcionais e a interface desejada. Durante o desenvolvimento, ele também revisa o projeto e fornece feedback para os programadores. O escritor é responsável pela criação das especificações e documentação necessária para a equipe e pela documentação que será usada fora do ambiente de desenvolvimento, como por exemplo, manuais para usuários.

\footnotetext{
${ }^{13}$ Comunicação Osmótica acontece quando o ambiente propicia uma fácil comunicação visual e verbal de forma que perguntas e respostas possam acontecer rapidamente, permitindo que todos sejam expostos a informações importantes do projeto e as absorvam involuntariamente, por osmose, por estarem em contato com elas.
} 


\section{Estratégias}

Com base em suas propriedades (página 63), a metodologia oferece um conjunto de estratégias, nas quais a equipe pode fazer adaptações conforme o seu contexto. Contudo, apesar da flexibilidade, duas práticas são indispensáveis: o desenvolvimento incremental em ciclos de no máximo poucos meses e reflexões de aprimoramento (reflection workshops) no modo de trabalho da equipe. As cinco estratégias sugeridas são:

1. Exploração de $\mathbf{3 6 0} 0^{\circ}$ - No início do projeto, a equipe identifica os pontos que não possui entendimento suficiente para se sentir confortável e os explora em todas as direções para tomar conhecimento das possíveis soluções. Esta exploração pode durar alguns dias ou até duas semanas se houver muitas incertezas atreladas ao projeto e as suas tecnologias. Durante a exploração a equipe colhe ou produz amostras do projeto para aumentar a sua compreensão. Amostras de valor de negócio podem ser colhidas com clientes e usuários através de perguntas e respostas que indicarão os principais casos de uso e tipos de usuários do sistema. Amostras de requisitos podem ser casos de uso pouco detalhados que indicarão as principais funcionalidades. Os desenvolvedores podem produzir amostras de tecnologia fazendo pequenas aplicações com as tecnologias candidatas e amostras de modelagem criando esboços do projeto.

2. Vitória Antecipada - O projeto deve começar com um objetivo que a equipe possa atingir relativamente rápido. A primeira porção entregue de código visivelmente funcional, dá à equipe a sensação de vitória e uma posição mais confortável no projeto. Os participantes aprendem com os estilos de trabalho dos demais e já podem refletir sobre como se aprimorar. Para usuários e o patrocinador, a equipe transmite uma imagem positiva. Usuários já passam a ver o software e o patrocinador vê algum resultado do investimento.

3. Esqueleto que Anda - Para cada tipo de projeto pode haver estruturas ou operações essenciais para o sistema ou para suas funcionalidades que representam o esqueleto do projeto, tal como a comunicação entre máquinas distribuídas, entre tecnologias ou entre sistemas heterogêneos. Este esqueleto deve ficar pronto e funcional cedo para permitir que ele seja testado isoladamente com mais facilidade e tornar a implementação e os testes das próximas funcionalidades mais realistas.

4. Rearquitetura Incremental - A arquitetura do sistema evolui a partir do Esqueleto que Anda até incorporar todas as sofisticações exigidas. A equipe parte de uma solução simples 
sabendo que o esqueleto possui estruturas básicas que possivelmente serão substituídas com o crescimento do sistema. O trabalho de reestruturação pode aparentemente ser um pouco maior, mas essa estratégia ajuda o projeto a alcançar a Vitória Antecipada e ajuda a equipe a entregar freqüentemente enquanto aumenta seu conhecimento sobre a complexidade do sistema e modela soluções arquiteturalmente mais sofisticadas.

5. Radiadores de Informação - Painéis colocados em lugares de fácil visualização onde as pessoas possam obter informações a respeito do projeto são os Radiadores de Informação. Eles devem ter novos dados inseridos fácil e freqüentemente e devem ser grandes o suficiente para serem vistos e compreendidos mesmo por observadores desavisados. Geralmente radiadores são cartazes ou pôsteres, mas também podem ser desenhados em quadros brancos ou ficar disponíveis na Web. As informações exibidas são as que a equipe julga mais relevantes para o seu trabalho. Podem ser sobre o código, a quantidade e o estado dos testes, tarefas pendentes ou mesmo o resultado do último Reflection Workshop.

\section{Práticas}

Das nove práticas propostas, apenas o Reflection Workshop é obrigatória, pois ele auxilia a equipe a melhorar continuamente. As demais ajudam a equipe a fazer planejamento, estimação e priorização, além de, no âmbito geral, auxiliarem na condução do projeto.

1. Modelagem da Metodologia - Para definir uma metodologia compatível com a equipe, entrevistas com os participantes são conduzidas para identificar os principais pontos positivos e negativos das últimas experiências da equipe. A partir das respostas das entrevistas, a equipe realiza um workshop de modelagem da metodologia para chegar ao conjunto de práticas que atenda às suas necessidades e às do projeto. Na entrevista, que pode ser individual ou em grupos, cada participante conta sua visão do último projeto, identifica os pontos positivos, que devem ser mantidos, os pontos negativos, que precisam ser corrigidos, aponta suas prioridades e levanta outras questões que julgar relevantes. No workshop de modelagem da metodologia os participantes analisam a lista de itens positivos para identificar quais podem ser facilmente incorporados ao projeto. Depois, com a lista de itens indesejados, todos procuram maneiras de conduzir o projeto evitando-os, formando uma lista com um conjunto de práticas, regras e convenções que se tornarão a base da metodologia e serão melhoradas ao longo do tempo à medida que as pessoas forem tendo novas idéias. 
2. Reflection Workshop - A equipe deve parar o desenvolvimento periodicamente para refletir sobre o seu trabalho. Para a reunião de reflexão, um formato bastante usado consiste em encontrar respostas para três questões: "O que deve ser mantido?", "Onde estamos tendo problemas?" e "O que vamos tentar na próxima iteração?". Além dessas, Norm Kerth descreve várias atividades para serem realizadas durante retrospectivas [Ker01]. O resultado do Reflection Workshop são três listas com as respostas para as perguntas apresentadas no formato de um radiador de informações que fica exposto no ambiente de desenvolvimento para ajudar a equipe a se lembrar das conclusões a que chegou durante a reflexão.

3. Planejamento a Jato - Baseado no Jogo do Planejamento de XP [BF01], esta variação se propõe a fazer um planejamento rápido onde os patrocinadores e usuários direcionam o projeto por períodos de até 3 meses. Desenvolvedores, patrocinadores, usuários representantes e analistas de negócios se reúnem para concordarem com um plano de curto prazo. Todos discutem e escrevem tarefas necessárias no projeto com ajuda de cartões de história. Os cartões são organizados na mesa por dependência. Todos revisam o conjunto de tarefas com o objetivo de adicionar as que não foram lembradas. A equipe de desenvolvimento anota no cartão suas estimativas de duração, o nome daqueles que se comprometem com a tarefa e, quando existirem, as dependências externas ao projeto. A equipe reavalia as dependências e as referencia nos cartões. O Esqueleto que Anda, a primeira versão e a primeira fonte de receita são planejados para ajudar os usuários e a equipe de negócios a alinhar suas expectativas com a realidade do desenvolvimento. Assim é feito um esforço para visualizar como esses marcos se posicionam em meio às tarefas técnicas. Além da primeira versão, outras podem ser definidas simplesmente agrupando os cartões. Por fim, o resultado do planejamento é fotografado para virar um radiador de informações, ou a posição dos cartões é reproduzida colando-os em uma parede e, para evitar que a ordem seja perdida, os cartões são numerados.

4. Estimação Delphi Baseada em Experiências - Para estimar a duração total do desenvolvimento de um software, esta técnica considera os principais pontos que influem na velocidade do desenvolvimento e a experiência dos profissionais envolvidos [Coc04, Coc98]. Após fazer a Exploração de $360^{\circ}$, os membros mais experientes da equipe reúnem-se e criam uma grande tabela. Cada um coloca os elementos que podem influenciar na velocidade do projeto em uma linha, tais como: arcabouços, ferramentas para o banco de dados, casos de uso, interface para o usuário, regras de negócio, etc. Cada participante escreve em sua coluna o quanto acha que há de peso em cada fator para o projeto. Após uma rodada, o primeiro adiciona uma nova 
coluna e coloca sua estimativa revisada baseado nas opiniões que obteve dos demais durante a primeira rodada. Geralmente três rodadas são suficientes para estabilizar as estimativas. Após isso, os elementos mais importantes são multiplicados por fatores que indicam o número de classes de negócio, classes técnicas, páginas (ou telas), casos de uso, etc. Esses resultados podem ser usados para determinar a quantidade de pessoas na equipe ao longo do projeto, a distribuição do nível de experiência e balancear versões baseado em dependências técnicas e de negócios [Coc04].

5. Reunião Diária em Pé - Para evitar que a reunião torne-se um dispêndio de tempo com discussões infindáveis e inúmeras distrações, a prática de reuniões rápidas em pé, originária do Scrum [SB02], foi incorporada como uma forma de disseminar informações, identificar dificuldades e verificar as prioridades. Durante a reunião, cada desenvolvedor simplesmente responde aos demais a três perguntas: "O que eu fiz ontem?", "O que eu vou fazer hoje?" e "Que problemas estou tendo?".

6. Descoberta das Interações do Usuário - O desenvolvimento da interface do usuário requer a identificação dos principais grupos de usuários e a compreensão de suas necessidades. A partir da abordagem de Design Centrado no Uso, sugerido por Constantine [CLW00], Jeff Patton criou uma adaptação para o contexto ágil. Em um encontro que reúne os principais envolvidos no projeto com representantes de grupos de usuários com interesses diversos, serão criados vários diagramas e cartazes que servirão de base para a criação da interface e de guia para a compreensão dos objetivos e prioridades do projeto. Para esta reunião, o ideal é um grupo de 8 a 12 participantes, reunidos em um ambiente confortável com quadros brancos, cartões em branco, canetas coloridas, papel para rascunho e guloseimas. Os tipos de perfis de usuário são identificados, nomeados e colocados em cartões junto com seus principais objetivos, a freqüência com que acessam o sistema e a importância do ponto de vista dos analistas de negócios (Alta, Média ou Baixa). Os cartões são agrupados conforme os objetivos e colados em um quadro ou em uma superfície de papel para que linhas possam ser desenhadas para unir grupos relacionados ou dependentes, criando o Modelo de Papéis de Usuários. Os mais experientes no negócio votam nos tipos de usuários determinantes para o sucesso do software, criando o foco dos perfis. De cada papel são extraídas as operações que os usuários precisam realizar para alcançar seus objetivos. Os cartões de operações são agrupados por similaridade e os grupos são unidos por linhas para indicar os relacionamentos e a ordem em que elas acontecem, criando o Modelo de Tarefas. Novamente os participantes votam, desta vez, nas 
tarefas de maior valor de negócios ou que serão realizadas mais vezes. A partir do modelo de tarefas, os lugares no sistema onde essas operações se encontram são identificados (Contextos de Interação) e ligando-os, é obtido um mapa de navegação do software. Depois, em um novo espaço são desenhados dois eixos, o eixo horizontal representa o tempo, no caso, o momento em que o usuário irá realizar cada operação e, o vertical, a importância para o negócio. Uma cópia dos cartões é feita para dispô-los sobre o plano deste eixo de forma que os do topo sejam os de valor de negócio mais altos, geralmente formando um dos fluxos de operações que o usuário fará; esta fileira é uma possível primeira versão. O resultado desta reunião será: 1) a identificação das principais funcionalidades e prioridades do software e, 2) vários radiadores de informação que serão colocados no ambiente de desenvolvimento.

7. Mini-Processos - A etapa de introdução de processos para equipes ou empresas requer a compreensão do panorama geral para depois detalhes poderem ser explorados. Peter Merel inventou a Hora Extrema [Mer], que introduz XP em 1 hora através de duas iterações de 30 minutos. A abordagem de Mini-Processos permite introduzir novas metodologias ou práticas em seções curtas e didáticas. Ela pode ser usada para apresentar metodologias através do desenvolvimento de aplicações simples ou introduzir técnicas como Reflection Workshop, Descoberta de Interações de Usuário ou Planejamento a Jato com versões simplificadas desses processos com duração de poucos minutos, para depois apresentar os detalhes em seções completas.

8. Programação Lado a Lado - Ao trabalhar lado a lado, cada programador terá sua estação de trabalho e uma tarefa para fazer. No entanto, por estarem sentados próximos, podem manterse atualizados sobre a evolução das tarefas do companheiro. Este modelo vai um passo além da comunicação osmótica, pois além de facilitar a troca de informações, os envolvidos podem acompanhar o trabalho do parceiro apenas olhando para o lado e contribuir diretamente para melhorá-lo através de revisão de código e de sugestões de implementação.

9. Burn Charts - Para acompanhar o andamento do projeto, é importante identificar medidas adequadas e deixá-las visíveis através de radiadores de informação. Gráficos burn-up e burndown são maneiras de exibir e documentar a evolução do desenvolvimento. O eixo horizontal representa o tempo (geralmente em dias) e o eixo vertical a quantidade de trabalho ${ }^{14}$. Nos casos em que o volume de trabalho sofre mudanças durante o período acompanhado, esses

\footnotetext{
${ }^{14}$ Gráficos burn-up são interpretados com foco na quantidade de tarefas testadas e entregues; para gráficos burn-down, a análise é feita com foco nas tarefas que ainda precisam ser concluídas.
} 
gráficos perdem expressividade. Para lidar com essas situações, variantes do burndown podem ser usadas para manter a representatividade do gráfico [Coh06, Coc04].

\subsubsection{Lean Software Development}

No fim da década de 40, a Toyota ainda era uma pequena empresa que percebeu a possibilidade de crescimento e aquisição de uma fatia do mercado de automóveis se conseguisse produzir veículos baratos e mantê-los com alta qualidade. Com este desafio, Taiichi Ohno e Shigeo Shingo lideraram o processo de corte de gastos na linha de produção da Toyota. Sua filosofia foi eliminar tudo que pudesse ser um desperdício desde a fabricação até a entrega dos produtos. As mudanças propostas por Ohno e Shingo definiram novos paradigmas para a manufatura, logística, linha de montagem e desenvolvimento de produtos criando as bases para o pensamento Lean ${ }^{15}$. As técnicas de produção Just-in-Time, que eliminou o estoque, e a Stop-the-Line, que pára a produção se um defeito é encontrado, formaram os pilares do que mais tarde se tornou o Sistema de Produção da Toyota [Ohn88]. Depois, os mesmos princípios foram estendidos para cadeias de abastecimento e para o desenvolvimento de produtos.

O Desenvolvimento de Software Lean deriva do Sistema de Desenvolvimento de Produtos. Portanto, ele agrega a capacidade de adaptação rápida e efetiva a um grande conjunto de demandas do cliente, combinada à habilidade de produção regular e escalável, que continuamente melhora o processo interno e ao mesmo tempo é flexível para a produção de vários tipos de produtos. A implantação do desenvolvimento Lean implica, muitas vezes, em mudanças estruturais da instituição, por isso a sua utilização depende da aceitação de suas idéias pelas esferas de comando da empresa. $\mathrm{O}$ impacto das mudanças estará além do escopo do trabalho das pessoas individualmente, elas abrangerão o processo como um todo, por isso é imperativo que os principais envolvidos na tomada de decisão tenham seus ideais alinhados com este modo de trabalho.

Os princípios Lean são focados na otimização de processos com aumento de qualidade e redução de custos. Eles podem ser utilizados na produção e desenvolvimento de praticamente qualquer tipo de produto através de práticas adequadas a cada contexto. Para o desenvolvimento de software, o modelo Lean possui 7 princípios [PP03], dos quais a eliminação de desperdício é o principal deles.

\footnotetext{
${ }^{15} \mathrm{O}$ termo lean significa: magro; sem gordura.
} 


\section{Princípios}

Os princípios Lean apontam meios para aumentar a qualidade do processo e do produto pela aplicação de práticas que afetam o modo de tratar ou executar tarefas e o fluxo de trabalho com foco na otimização dos resultados gerais do processo de produção [PP06].

1 - Elimine o desperdício que pode acontecer sob vários pontos de vista, dentre eles, desperdício de: dinheiro, recursos, tempo, esforço e espaço. O criador do pensamento Lean define desperdício como:

"Tudo aquilo que não acrescenta valor ao produto na percepção do cliente."

Taiichi Ohno

Cada etapa e atividade realizada no processo deve necessariamente contribuir para que o produto final seja construído mais rapidamente, com mais qualidade ou a um custo mais baixo.

Funcionalidades incompletas são desperdício porque despendem esforços para serem iniciadas e não adicionam valor ao software. Pedaços de código incompletos tendem a se tornar obsoletos, mais difíceis de serem integrados e os programadores lembram menos a respeito da intenção inicial do código. Por estarem inacabadas, foi um desperdício começá-las. Mesmo quando forem concluídas, essas funcionalidades não deixarão de representar desperdício pois o esforço inicial poderia ter sido feito mais tarde em troca da implementação de funcionalidades que entrariam em produção primeiro. Em uma análise extrema, funcionalidades em progresso também são um desperdício pois exigiram um investimento inicial que está sofrendo depreciação até que elas sejam concluídas e acrescentem valor ao software.

Excesso de processos é um desperdício porque eles demandam recursos e aumentam o tempo para a conclusão das tarefas. A criação de documentos infla o processo e causa desperdício pois eles consomem tempo para serem produzidos, sem garantias de que alguém irá lê-los. Documentos ficam desatualizados e podem ser perdidos, tornam a comunicação mais lenta e reduzem o poder comunicativo, pois são um meio de comunicação de via única no qual não é possível que escritor e leitor interajam em tempo real. Além disso, muitas vezes, documentos representam apenas formalismos burocráticos que não acrescentam valor ao software. Processos complexos aumentam a quantidade de documentos, por isso também caracterizam desperdício. Processos envolvem comunicação e atividades de gerenciamento, quanto mais simples e objetivos eles forem, menos pessoas serão necessárias, 
menos etapas precisarão ser cumpridas até a conclusão de um ciclo e, portanto, o processo inteiro será mais rápido e barato.

Antecipar funcionalidades é um desperdício porque aumenta a complexidade do software desnecessariamente com mais código, mais esforços com testes e mais integrações. Mais funcionalidades criam mais pontos de falha em potencial sem ter certeza de que alguém usará os recursos extras. Os $64 \%$ de funcionalidades raramente ou nunca utilizadas apontados por Johnson evidenciam esse tipo de desperdício [Joh02].

Troca de tarefas é uma forma de desperdício porque um número excessivo de mudanças de contexto reduz a produtividade. Clark e Wheelwright concluíram que a máxima produtividade é alcançada com duas tarefas pois a troca de atividades é benéfica quando algum obstáculo impede a tarefa atual de evoluir [CW93]. No entanto, trocar muitas vezes de atividade reduz a produtividade porque exige muitas mudanças do contexto mental. Alocar desenvolvedores em mais de um projeto também é um desperdício porque as necessidades de um projeto não levam em conta a situação dos outros. Isso causa trocas de contexto em momentos de necessidade de um dos projetos, deixando tarefas incompletas e podendo causar efeitos em cadeia ao obrigar que outros programadores também mudem suas tarefas para compensar a ausência daqueles que mudaram primeiro.

Esperar causa atraso e portanto desperdício. Esperas por requisitos, por testes, por aprovação ou por feedback retardam o fluxo do desenvolvimento ou a identificação de problemas. Desenvolvedores precisam tomar decisões constantemente e não é possível assumir que toda a informação está documentada. A falta de disponibilidade de informações obriga o programador a seguir por um dos três caminhos: 1) pesquisar para tentar descobrir a resposta; 2) trocar de tarefa (que é uma forma de desperdício); ou 3) fazer suposições e prosseguir, aumentando a chance de gerar funcionalidades erradas.

Movimentações causam desperdício. Trocar pessoas de equipes causa perda de conhecimento pois o conhecimento tácito é difícil de transmitir [WJR90]. Movimentação indica a falta de centralização. Informações descentralizadas, pessoas desagrupadas ou artefatos espalhados aumentam os esforços quando o acesso a algum desses elementos é necessário. O acesso não-trivial a elementos dispersos tira o foco da tarefa principal. Dificuldades para comunicação também provocam desperdício porque exigem mais esforços para a troca de informações.

Defeitos são desperdício porque o custo para corrigi-los aumenta com o tempo. À medida que o projeto evolui, a complexidade do código aumenta, com isso, a localização e a remoção de um defeito 
torna-se mais difícil [ $\left.\mathrm{SBB}^{+} 02\right]$. Algumas vezes corrigir defeitos também é uma forma de desperdício pois novos defeitos aparecerão e isso pode causar um ciclo vicioso que consome tempo e os recursos do projeto. Portanto, tão importante quanto corrigir defeitos rapidamente é identificar a sua causa para evitar que novos erros sejam introduzidos pela mesma razão, seja ela uma falha de comunicação ou um problema no processo.

2 - Amplifique o aprendizado a partir da experiência adquirida. Lições devem ser extraídas das experiências vividas pela equipe e incorporadas ao processo fazendo com que dificuldades sejam fonte de conhecimento e contribuam para o amadurecimento da equipe e do processo. Usar um processo definido engessa o aprendizado, por isso possibilidades devem ser deixadas para que o processo seja melhorado continuamente. Identifique o problema, localize a sua causa, crie uma solução, implemente-a, verifique os resultados e adapte-se à nova realidade, este é o ciclo de melhoria contínua proposto por Deming [Dem86].

3 - Adie comprometimentos e mantenha a flexibilidade para adaptação a mudanças. Ambientes com muita incerteza dificultam previsões. Adiar decisões permite que as escolhas sejam apoiadas por mais experiência e conhecimento adquiridos no decorrer do processo.

Para retardar decisões durante a construção de sistemas é importante que a equipe crie a capacidade de absorver mudanças tratando os planejamentos como estratégias para atingir um objetivo e não como comprometimentos. Assim, mudanças serão vistas como oportunidades para aprender e atingir as metas.

4 - Entregue rápido software funcional. Rapidez entre um pedido e uma entrega e entre a entrega e as percepções de quem o solicitou permite que o cliente e desenvolvedores aprendam e melhorem através de feedback veloz, atualizado e confiável. Com ciclos rápidos, o desenvolvimento caminha através de um processo iterativo no qual o cliente refina suas necessidades e as obtém implementadas já no próximo ciclo. Iterações curtas trazem mais experiência para a equipe e aumentam a sua segurança para tomar decisões. Mary Poppendieck recomenda [PP03]:

“...entregue o que foi pedido tão rápido que os clientes não tenham tempo de mudar de idéia".

Mary Poppendieck

Seguindo este conceito, a chance de entregar software desatualizado ou incompleto será menor e 
a equipe de desenvolvimento sempre atenderá às expectativas do cliente.

5 - Valorize a equipe de desenvolvimento. A equipe de desenvolvimento é responsável pela confecção do produto que é entregue ou usado pelo cliente, o software. O conhecimento dos detalhes técnicos deve ser levado em consideração na tomada de decisões a na definição de processos.

Não trate as pessoas simplesmente como recursos. Quanto mais a equipe tiver seu trabalho reconhecido, mais motivada e interessada na melhoria de processo ela ficará. Quanto mais a equipe puder contribuir e aprender, mais comprometida ela ficará.

6 - Adicione segurança ao software. A equipe deve implementar soluções que a deixem segura de que estão construindo um produto de qualidade. Utilizando uma arquitetura adequada, mantendo uma alta cobertura de testes automatizados e preservando a flexibilidade para mudanças, adaptações e extensões são meios de trazer segurança e motivação para alcançar níveis mais elevados de qualidade. Ao invés de gastar tempo para encontrar e corrigir defeitos, invista os esforços prevenindo-os através de vários tipos de teste.

7 - Otimize o todo. A criação de grandes sistemas envolve soluções integradas que devem prover bons resultados perante uma análise global do software. Os pontos de vista dos clientes e dos usuários equivalem a visões de alto nível do sistema. Otimizações macro canalizam os esforços para aumentar a satisfação dos usuários finais através de um produto consistente. Otimizações pontuais nem sempre são sinérgicas quando precisam funcionar simultaneamente. Para resolver problemas, busque e elimine as suas causas, não os seus sintomas.

Lean ainda recomenda a escolha de métricas de alto nível que sejam representativas para identificar a evolução. Essas métricas devem levar em consideração também a qualidade e a satisfação do cliente, pois a partir delas será possível avaliar quais trocas são vantajosas.

A proposta de Lean chega a ser considerada radial porque é mais do que uma mudança de hábitos, chega a ser uma mudança de cultura [PP06]. Karlsson e Åhlströn relatam dois anos de experiências com a implantação de Lean e apontam diversos obstáculos encontrados durante o processo de transição. Eles recomendam duas práticas para tornar este processo mais confortável: 1) estabelecimento da consciência sobre os conceitos e aceitação da necessidade de mudança e, 2) assegurar-se que a transição mantenha o processo consistente, o que significa que a etapa de mudanças deve adotar práticas de forma suave o suficiente para que o processo continue funcionando em todos os momentos [KA96]. 


\section{Capítulo 3}

\section{Experiências com Desenvolvimento Ágil}

As experiências descritas neste trabalho aconteceram entre 2003 e 2007 em projetos dentro da universidade e em alguns segmentos da indústria. As equipes com quem trabalhamos eram mistas, formadas por indivíduos com experiência em desenvolvimento ágil e desenvolvedores iniciantes, com pouco conhecimento no desenvolvimento de sistemas de grande porte e muitas vezes nenhuma experiência com metodologias ágeis.

Nosso objetivo primário foi identificar maneiras de melhorar a produtividade e agregar a máxima qualidade ao produto em desenvolvimento sem, no entanto, prejudicar a produtividade da equipe no longo prazo. Estas metas motivaram a experimentação de diversas práticas para gerenciamento e organização da equipe e para implementação do software.

\subsection{Na Universidade - IME-USP}

A necessidade de desenvolvimento de software que a USP precisa é imensa. Inicialmente para a produção de inúmeros sistemas de uso interno para os departamentos e, em segundo lugar, para a manutenção e evolução dos sistemas existentes. No entanto, a escassez de pessoal qualificado para tal desenvolvimento provoca atraso na produção dos sistemas novos e ainda impossibilita que a manutenção aconteça de maneira satisfatória.

No decorrer deste capítulo vamos identificar as dificuldades para o desenvolvimento de software dentro da universidade e apresentar nosso modelo para a produção de software utilizando recursos disponíveis dentro da universidade. 


\subsubsection{Os Sistemas da USP}

O Departamento de Informática (DI) da Universidade de São Paulo (USP) é responsável pelo desenvolvimento dos grandes sistemas que a universidade necessita. Entre eles estão o Júpiter, o Fênix, o Mercúrio, o Marte e, mais recentemente, o Janus ${ }^{1}$. Para a criação, manutenção e operação desses sistemas são investidos milhões de reais anualmente com o objetivo de atender às necessidades da universidade como um todo. Apesar desses esforços, ainda há uma enorme carência por sistemas menores, específicos para os departamentos de cada unidade da USP. A falta desses sistemas obriga a universidade a ter mais funcionários para realizar as tarefas de forma manual e sujeita a erros operacionais.

Percebendo essa carência por software, algumas iniciativas de desenvolvimento acontecem a partir de esforços isolados de alunos durante seus trabalhos de conclusão de curso ou projetos na pósgraduação. Desses trabalhos, somente uma parcela evolui ao ponto de se tornar estável e confiável o suficiente para ser usado como uma solução dentro da universidade. Um destes é o Panda ${ }^{2}$, um sistema de acompanhamento didático que foi usado durante vários anos pelos professores do IME e por alunos de diversos institutos da USP. Apesar deste caso de sucesso, outros softwares ainda fazem-se necessários. Seções importantes, como a biblioteca do IME, ainda não possuíam um sistema adequado.

\subsubsection{Colméia}

Apesar de existirem vários sistemas gerenciadores de biblioteca com código aberto ${ }^{3}$, muitos ainda não possuem todas as funcionalidades desejadas. Por outro lado, sistemas comerciais exigem um investimento financeiro muito acima dos padrões da maioria das instituições brasileiras, como pequenas bibliotecas, acervos escolares, igrejas e outras instituições públicas. Ademais, seria difícil para elas sustentar os gastos de manutenção e investir em atualizações de versão. Um representante dessas instituições era a biblioteca Carlos Benjamin de Lyra, do IME-USP, que possui uma extensa coleção de livros e periódicos de Computação e o segundo maior acervo de Matemática da América Latina. Até 2003, ela figurava entre as instituições que praticamente não possuíam sistemas bibliotecários e

\footnotetext{
${ }^{1}$ Respectivamente: http://sistemas2.usp.br/jupiterweb, http://sistemas.usp.br/fenixweb, http: //sistemas.usp.br/mercurioweb, http://sistemas.usp.br/marteweb e http://sistemas.usp.br/janus

${ }^{2}$ http://panda.ime.usp.br

${ }^{3}$ Koha (http://www.koha.org), OpenBiblio (http://obiblio.sourceforge.net), Emilda (http://www. emilda.org), LearningAccess (http://www.learningaccess.org/website/techdev/ils.php), Gnuteca (http: //www.gnuteca.org.br), entre outros.
} 
operavam manualmente.

Este cenário motivou o investimento de tempo e esforço para a pesquisa e desenvolvimento de um software com código aberto que atendesse aos requisitos de bibliotecas universitárias, pois estas possuem características particulares, em função da grande variedade de tipos de usuários e da vasta coleção de obras periódicas compreendidas por revistas científicas, jornais e títulos que temporariamente publicam novos volumes e fascículos. Esta coleção é de suma importância para os pesquisadores e alunos da universidade, mas não possuía um software capaz de gerenciá-la de maneira adequada. Essa necessidade foi a que culminou com o início do desenvolvimento do Colméia ${ }^{4}$, o sistema de gerenciamento bibliográfico criado pelo IME-USP para preencher as suas necessidades e contribuir com a comunidade de software livre.

Para produzir o Colméia, dezenas de pessoas, incluindo alunos, professores e funcionários do IME-USP, se motivaram com o objetivo de produzir um sistema que inicialmente ajudaria centenas de pessoas do instituto e com potencial para atender a milhares de usuários em diversas instituições brasileiras. Essa colaboração permitiu que fossem utilizados apenas os recursos já disponíveis dentro da universidade, sem que inicialmente nenhum centavo extra fosse gasto pela instituição. Em agosto de 2003 o projeto se iniciou apoiado pelo esforço de desenvolvimento dos alunos de duas disciplinas no curso de computação do IME-USP, usando um modelo de desenvolvimento empírico apoiado pelas práticas de XP. O seu principal ciclo se estrutura em duas fases complementares e iterativas. A Fase Incremental dura aproximadamente 4 meses com dedicação individual de aproximadamente 7 horas semanais e tem como objetivo produzir um novo conjunto de funcionalidades e, em seguida, a Fase de Maturação que foca no aprimoramento do software produzido na fase anterior para colocá-lo em produção.

Como o processo que optamos baseou-se em um modelo empírico, sabíamos que seria preciso adaptá-lo e melhorá-lo no decorrer do desenvolvimento, por isso decidimos apoiar a sua evolução com conceitos e práticas de métodos ágeis e adotar uma arquitetura que prevê a existência de vários subsistemas. Para tanto criamos o banco de dados dividido em módulos, seguindo os resultados das pesquisas de Barreira e Ferreira [BJFG04,FF00,FB99] e introduzimos no início do projeto uma camada de acesso às estruturas do banco de dados formada por stored procedures, que tornam a modelagem do banco de dados transparente para a camada de negócios e oferece as operações para manipulação dos dados, permitindo que a modelagem do banco de dados evolua sem afetar os sub-

\footnotetext{
${ }^{4}$ http://colmeia.incubadora.fapesp.br
} 
sistemas que o utilizam e evitando que eles tenham que tratar descasamentos de abstrações entre os modelos de objetos e relacional (impedance mismatch) [Kee93].

A camada de interface do banco conta com 158 stored procedures públicas e mais 29 privadas que encapsulam a lógica que lida com a complexidade da modelagem do banco e permitem adicionar, remover, modificar e encontrar dados em 134 tabelas que armazenam os dados de 30 tipos diferentes de usuários, 8 tipos de obras e informações referentes aos processos de empréstimos e aquisição de novos exemplares.

Para nosso estudo, o objetivo foi estabelecer o processo de desenvolvimento que propusemos e completar o ciclo para colocar em produção o subsistema de Gerenciamento de Periódicos. Conseguimos fazê-lo. Atualmente, o Colméia está parcialmente em operação dentro da biblioteca do IME-USP. Colocamos em produção o subsistema de Periódicos e, posteriormente, o de Controle de Pessoas com 90\% dos usuários. Através do ciclo de desenvolvimento que envolve os alunos foi implementada parcialmente a importação e exportação dos dados do acervo em formato MARC. O subsistema de Cadastro de Obras e o de Busca foram entregues pelos alunos da fase de implementação e precisam passar pela fase de maturação. Além do processo estabelecido, alguns alunos demonstraram interesse pelo projeto e produziram o subsistema de Empréstimos como trabalho de formatura.

\subsubsection{XP e a Academia}

Tanto métodos ágeis quanto os modelos tradicionais de desenvolvimento de software são voltados para a produção de sistemas na indústria. Em ambientes acadêmicos existem restrições e características que diferem do ambiente empresarial, no entanto esses métodos não as consideram. Beck sugere que XP seja adaptada sempre que ela não for adequada a um contexto [BA04]. O ambiente de produção do Colméia mescla fins didáticos com o desenvolvimento real de um sistema, o que aumenta a complexidade do processo e exige um número maior de adaptações para tornar a metodologia adequada a este contexto. Identificamos as principais características do projeto que requereram atenção especial e as apresentamos a seguir junto com as soluções que encontramos para adaptar XP.

Alguns papéis característicos da indústria assumem formas diferentes dentro de uma universidade. Os desenvolvedores são alunos ao invés de empregados de uma empresa, o papel do superior é substituído pela figura do professor e o cliente, que geralmente paga pelo software, neste caso é representado por funcionários do instituto com interesse em colaborar com o projeto. Essas diferenças causam mudanças na maneira como as pessoas se relacionam e como se posicionam em relação ao 
projeto (Tabela 3.1). Percebemos basicamente dois padrões de dedicação entre os alunos: aqueles que tratavam as atividades da disciplina como uma lista de obrigações que deveriam ser cumpridas para conseguir uma determinada avaliação em seu boletim e aqueles preocupados em concluir as tarefas com que se comprometeram para apresentar avanços ao clientes. O primeiro grupo compreende cerca de $2 / 3$ dos alunos e caracteriza-se pela preocupação em cumprir um determinado número de horas de programação. Para estes foi importante definir um critério de aprovação para definir o mínimo de contribuição esperado de cada um. O 1/3 restante foca suas preocupações em conseguir soluções para as tarefas. Quando a dificuldade das tarefas cresce durante a implementação este grupo caracteriza-se por buscar soluções alternativas que também resolvam o problema.

A aplicação de XP dentro da universidade afeta também a aplicação de algumas das práticas propostas por Beck e Andres [BA04]. Das 13 práticas primárias e 11 práticas corolárias de XP, destacamos aquelas que têm seu uso dificultado no ambiente acadêmico:

- Time Completo: Equipes formadas por alunos não possuem membros muitos experientes. No entanto, o ambiente acadêmico é propício para o aprendizado de habilidades ausentes. Elas podem ser adquiridas individualmente e propagadas para os demais através de programação em pares ou exemplos de código.

- Ciclo Trimestral: Ciclos longos geralmente não são possíveis porque as atividades acadêmicas são muitas vezes semestrais. Cada semestre conta com aproximadamente quatro meses letivos. Portanto, mesmo projetos anuais são interrompidos por férias e por isso têm dificuldades em estabelecer ciclos contínuos de desenvolvimento e entrega de releases.

- Design Incremental e Desenvolvimento Dirigido por Testes: A pouca experiência com o desenvolvimento de sistemas dificulta ou retarda a criação incremental de bons designs e a implementação de testes a priori, pois os alunos não dominam essas técnicas. Algumas vezes eles ainda desconhecem testes automatizados.

- Continuidade da Equipe: Atividades acadêmicas em equipes tendem a ser curtas. Longos trabalhos com grupos grandes estão sujeitos a dificuldades para avaliação individual e a desistências que podem prejudicar toda a equipe. Projetos grandes acabam usando equipes ou participantes que se renovam periodicamente. Esta rotatividade é exatamente oposta ao que a prática de XP defende. 


\begin{tabular}{|c|c|c|}
\hline Fator & Indústria & Academia \\
\hline Hierarquia & $\begin{array}{l}\text { Apesar de XP propor uma equipe } \\
\text { não-hierárquica, sempre existe um } \\
\text { superior responsável pela equipe e a } \\
\text { quem ela se reporta. }\end{array}$ & $\begin{array}{l}\text { Entre alunos e professores esta hie- } \\
\text { rarquia é menos rígida pois o pro- } \\
\text { fessor apenas orienta e o aluno tem } \\
\text { liberdade para tomar suas decisões, } \\
\text { pois isto irá determinar a sua avali- } \\
\text { ação na disciplina. }\end{array}$ \\
\hline Remuneração & $\begin{array}{l}\text { Salário e benefícios oferecidos pela } \\
\text { empresa. }\end{array}$ & $\begin{array}{l}\text { Sem remuneração ou com bolsas de } \\
\text { auxílio estudantil, com valores mais } \\
\text { baixos que os salários pagos nas em- } \\
\text { presas. }\end{array}$ \\
\hline Cobrança & $\begin{array}{l}\text { O cliente sente-se mais à vontade } \\
\text { para realizar pressão sobre a equipe } \\
\text { pois está pagando pelo produto e de- } \\
\text { seja que suas vontades sejam aten- } \\
\text { didas. }\end{array}$ & $\begin{array}{l}\text { Os clientes estão colaborando com } \\
\text { o projeto sem fazer investimento fi- } \\
\text { nanceiro próprio. }\end{array}$ \\
\hline Relacionamento & $\begin{array}{l}\text { E mais formal pois as pessoas preci- } \\
\text { sam respeitar as regras da empresa } \\
\text { e manter um tratamento profissio- } \\
\text { nal entre os participantes da equipe } \\
\text { e pessoas externas. }\end{array}$ & $\begin{array}{l}\text { A média de idade das equipes geral- } \\
\text { mente é menor e elas são formadas } \\
\text { por amigos e colegas de classe em } \\
\text { um ambiente sem grandes formali- } \\
\text { dades. }\end{array}$ \\
\hline Motivação & $\begin{array}{l}\text { Funcionários são motivados por me- } \\
\text { tas para obter melhor remunera- } \\
\text { ção ou a possibilidade de promoção, } \\
\text { pelo reconhecimento do seu trabalho } \\
\text { através de boas avaliações de seus } \\
\text { superiores. }\end{array}$ & $\begin{array}{l}\text { A avaliação na disciplina é o prin- } \\
\text { cipal fator motivador. Para alguns, } \\
\text { participar pela primeira vez de uma } \\
\text { equipe com várias pessoas é uma no- } \\
\text { vidade estimulante, para outros, co- } \\
\text { laborar com um grande projeto é o } \\
\text { maior estímulo. }\end{array}$ \\
\hline Dedicação & $\begin{array}{l}\text { Constante, com várias horas diárias } \\
\text { destinadas ao projeto. }\end{array}$ & $\begin{array}{l}\text { Parcial, com algumas horas por se- } \\
\text { mana divididas em duas ou três se- } \\
\text { ções de programação. }\end{array}$ \\
\hline Prioridades & $\begin{array}{l}\text { Para funcionários cujo desenvolvi- } \\
\text { mento de software é a principal fun- } \\
\text { ção essa atividade recebe alta prio- } \\
\text { ridade pois está associada à susten- } \\
\text { tabilidade de seu emprego. }\end{array}$ & $\begin{array}{l}\text { Para muitos alunos, independente- } \\
\text { mente de sua motivação, o tempo } \\
\text { precisa ser dividido com as ativi- } \\
\text { dades de outras disciplinas que ele } \\
\text { cursa em paralelo, igualmente im- } \\
\text { portantes para a sua formação. Por- } \\
\text { tanto a participação no projeto pos- } \\
\text { sui prioridade no máximo mediana. }\end{array}$ \\
\hline
\end{tabular}

Tabela 3.1: Comparação de fatores da indústria e da academia que influenciam no desenvolvimento de software. 
- Implantação Diária: A implantação diária é conseguida depois que a equipe encontra o seu ritmo de trabalho, porém, a alta rotatividade das equipes e as interrupções no ciclo de desenvolvimento dificultam o estabelecimento de um ritmo estável e seguro para implantar software em períodos curtos.

- Contrato de Escopo Negociável: O ambiente menos formal tende a facilitar a negociação do escopo entre os envolvidos.

- Pague-pelo-uso: O acordo entre os envolvidos com o projeto pode assumir diferentes significados para o pagamento. Ele pode significar a avaliação disciplinar, sem valores financeiros, ou corresponder ao pagamento de bolsas de auxílio a estudantes, nas quais os valores não são negociáveis, pois são determinados por regras da universidade.

\subsubsection{Fase Incremental}

A fase incremental acontece dentro de duas das disciplinas optativas do curso de Ciência da Computação do IME-USP, o Laboratório de Programação Extrema (LAB-XP) e o Laboratório de Banco de Dados (LAB-BD). A primeira ensina XP a mestrandos, doutorandos e alunos do penúltimo e último anos da graduação. Ela propõe que os alunos entrem em contato direto com as principais práticas de XP através de várias horas de programação trabalhando em um único projeto ao longo do semestre. O LAB-BD tem o objetivo de apresentar aspectos arquiteturais da implementação de SGBDs, exercitar a capacidade de modelagem relacional e aumentar a familiaridade dos alunos com a linguagem SQL. No entanto, apesar do LAB-BD construir os modelos incrementalmente, não usa explicitamente as práticas de XP.

O objetivo da fase incremental foi aproveitar o esforço de desenvolvimento dos alunos para produzir software que supra demandas da universidade. O Colméia é o principal e maior projeto produzido com auxílio do LAB-XP e do LAB-BD até o momento. Ele foi beneficiado com a implementação de 4 de seus módulos em conjunto com o LAB-XP: 1) o módulo para gerenciamento de periódicos, 2) o módulo de cadastro e gerenciamento de usuários, 3) o módulo de busca no acervo e 4) um módulo que implementou o uso do padrão MARC 21 [MAR07]. O LAB-BD colaborou com a criação e implementação do modelo relacional para todo o acervo e para os 30 possíveis tipos de usuários da biblioteca, colaborou também com a definição do fluxo navegacional para a aquisição de novos exemplares e para o empréstimo de obras. Assim como o Colméia, outros projetos de código aberto, 
como o Mico $\left[\mathrm{FGF}^{+}\right.$04], o Cigarra [FGK05], o Borboleta ${ }^{5}$, o $\operatorname{Archimedes}^{6}$, o GinLab e um aplicativo marcador de reuniões, também foram alavancados pelo LAB-XP através do desenvolvimento de diversas de suas funcionalidades pelos seus alunos.

\section{Laboratório de Programação Extrema}

A disciplina Laboratório de XP tem como pré-requisito o conhecimento de orientação a objetos. O seu programa prevê apenas quatro aulas teóricas no início do curso, nas quais são introduzidas: metodologias ágeis e programação extrema, testes automatizados e refatorações. As demais aulas acontecem em um ambiente que favorece as práticas de XP: um laboratório que segue as recomendações de Beck [BA04] e Cockburn [Coc06], onde o desenvolvimento dos sistemas é feito sob a perspectiva ágil, conforme descrevem Goldman et al. [GKdSeSY04].

Os alunos são inicialmente agrupados em equipes que variam de 4 a 12 participantes, de acordo com o tamanho e a complexidade do software que irão produzir. Cada equipe elege um tracker e o aluno mais experiente do time recebe o papel de coach. O professor atua como guia das equipes, auxiliando na condução do projeto e avaliando o que está sendo produzido. A disciplina conta ainda com um mestrando com experiência em desenvolvimento ágil, que atua como monitor auxiliando o professor nas atividades acadêmicas e as equipes na condução de seus projetos.

Para garantir que o software atenda às necessidades a que se propõe, as aulas são acompanhadas pelos clientes do produto em desenvolvimento, que geralmente são os futuros usuários, ou um cliente proxy que compreende os interesses dos usuários e é capaz de representá-los. Este ambiente proporciona aos alunos uma experiência muitas vezes inédita em suas jovens carreiras profissionais, aproximando-os de um cenário de desenvolvimento mais realista e parecido com os que irão encontrar fora da universidade.

A cada semana, os alunos realizam 2 seções de programação, uma de 2 horas e outra de 3 horas. Além disso, é recomendado que cada aluno dedique, no mínimo, mais duas horas por semana para atividades do projeto, não necessariamente ligadas à programação, podendo ser: leituras sobre XP, pesquisa ou estudo de tecnologias, compreensão das regras de negócio do sistema, preparação de estratégias de teste, entre outras. Ao todo são 7 horas semanais de dedicação, divididas em três seções, o que corresponde a menos do que um dia de trabalho por semana ${ }^{7}$. Considerando a duração

\footnotetext{
${ }^{5}$ http://borboleta.incubadora.fapesp.br

${ }^{6}$ http://archimedes.incubadora.fapesp.br

${ }^{7}$ Comparando com o turno de trabalho de 8 horas da indústria de software.
} 
da disciplina como aproximadamente 4 meses, que é o período letivo do semestre, chegamos a uma carga horária de aproximadamente 112 horas, que é menos do que 3 semanas de trabalho na indústria. Ao fim desse período, cada equipe apresenta formalmente a versão final do software que produziu e a entrega aos clientes.

Ao dividir 7 horas em três seções, podemos ter conseqüências positivas e negativas para o desenvolvimento. Para cada nova seção, um tempo é gasto para o desenvolvedor se concentrar no trabalho e se contextualizar sobre a situação do problema, uma vez que, graças à prática de propriedade coletiva, outros participantes de sua equipe podem ter modificado o código desde sua última seção de trabalho. Portanto realizar seções pequenas e temporalmente dispersas causa redução na produtividade. Por outro lado, para problemas que o programador ainda não sabe a solução, essa divisão torna-se interessante, pois o intervalo entre as seções de programação cria tempo para ele refletir sobre a tarefa, pesquisar ou perguntar para pessoas que entendam do assunto. Seções menos concentradas também colaboram com as situações em que o programador depende de fatores externos, como a resposta de um e-mail, autorizações, liberação de acesso, informações de terceiros ou mesmo processamentos de dados demorados, pois com apenas uma seção de trabalho semanal, quando esses eventos não acontecerem no mesmo dia da solicitação, o desenvolvimento teria que esperar por uma semana para evoluir, ou em alguns casos, apenas tomar atitudes para avançar com a obtenção das informações externas.

No decorrer das seções de desenvolvimento, as equipes executam todas as etapas da produção de um sistema. Inicialmente, realizam entrevistas com o cliente, acompanham a escrita dos cartões de história e escolhem as tecnologias. Junto com o professor e o cliente todos realizam o jogo do planejamento [BF01], estabelecendo prioridades, definindo estimativas e estabelecendo versões intermediárias até a entrega final. Durante a implementação, o cliente se mantém presente e disponível para o esclarecimento de dúvidas sobre as regras de negócio ou suas necessidades. Decisões arquiteturais e de modelagem são tomadas pela equipe sempre que necessário. Além disso, todos têm a obrigação de fazer testes automatizados e refatorações $\left[\mathrm{FBB}^{+} 99\right]$ e, invariavelmente, rever os planos iniciais de acordo com novas prioridades ou informações descobertas tardiamente. Sempre que as implementações atingem as versões intermediárias, a equipe realiza uma apresentação das funcionalidades concluídas e o cliente pode aprová-las ou não.

À medida que os alunos absorvem os valores ágeis, a orientação do professor e do monitor torna-se menos freqüente pois eles passam a conhecer as regras do jogo e descobrem como a equipe lida com cada uma. 


\section{Laboratório de Banco de Dados}

Nesta disciplina os alunos formam grupos de 3 a 6 participantes para desenvolver projetos que compreendem subdomínios no banco de dados do Colméia. O professor orienta as decisões de modelagem e fornece a base teórica para a construção do modelo. A disciplina também conta com um aluno experiente que atua como monitor, corrigindo os exercícios de SQL feitos pelos alunos.

Como o objetivo do banco de dados vai além dos fins didáticos da disciplina, uma nova atividade fez-se necessária e permitiu que os alunos exercitassem mais uma habilidade necessária na engenharia e construção de sistemas: a investigação. Os alunos realizam a coleta dos requisitos através de conversas com os funcionários e visitas à biblioteca para identificar quais dados precisavam ser armazenados e como eles se relacionam.

Durante o curso, são mescladas algumas aulas teóricas, onde são apresentados aspectos conceituais e as principais estruturas de gerenciadores de banco de dados (GBDs), com muitas atividades de modelagem, análise e implementação realizadas no laboratório. Como cada grupo lida com um subdomínio diferente, periodicamente apresentações são realizadas para que os demais possam compreender as soluções propostas por cada equipe e também contribuir com sugestões. Através de vários ciclos de investigação, modelagem e apresentação, a solução foi se refinando até alcançar um grau de elegância e sofisticação aceitáveis para um sistema deste porte.

No início do projeto, as disciplinas de LAB-BD e LAB-XP aconteciam em paralelo, com isso a modelagem do banco de dados e o desenvolvimento das camadas de interface e negócios aconteciam juntos, criando uma dependência muito forte entre as equipes, dificultando a tomada rápida de decisões e duplicando os esforços pois as duas equipes precisavam compreender as regras de negócio e sincronizar a modelagem de dados com a de objetos. Segundo Popperwick [PP03], isto representa excesso de esforço que encarece e atrasa a entrega do produto final. Para que o LAB-XP pudesse se utilizar do conhecimento adquirido durante o LAB-BD e produzir software de acordo com o que o banco desse suporte, o semestre de oferecimento do LAB-XP foi mudado para que as disciplinas se alternassem entre os semestres e a modelagem do banco de dados estivesse sempre com um passo à frente da implementação da camada de negócios e interface.

\subsubsection{Fase de Maturação}

A fase de maturação vem em complemento à incremental. Apesar de software produzido possuir as funcionalidades desejadas, vários motivos corroboram para que ele ainda não esteja pronto para 
entrar em produção:

- funcionalidades desenvolvidas podem estar aquém do mínimo necessário para o uso;

- padrões de codificação podem não ter sido seguidos pelos alunos;

- soluções mais elegantes ou simples podem ser implementadas por alunos mais experientes;

- o código pode precisar de refatorações;

- o código novo precisa ser integrado ao restante do projeto;

- equipes que se atrasam na implementação podem produzir código de menor qualidade para conseguir cumprir o prazo combinado;

- os testes podem estar incompletos.

Gilb [Gil88] e Jones [Jon96] apontaram ganho de qualidade com a inspeção de código. Além da programação em pares no LAB-XP, que é um tipo de inspeção, o software passa por um período de lapidação no Laboratório de Banco de Dados do IME/USP ${ }^{8}$, ou sob a responsabilidade de um mestrando, que passa a ser seu mantenedor e acrescenta recursos mais sofisticados ou otimizados e aproveita a experiência e o código para avançar com sua pesquisa.

Quando o software produzido entra em produção, os usuários identificam novas demandas, pequenos ajustes e erros e as reportam para o mantenedor. Este avalia caso a caso para classificar a requisição e definir se é uma correção ou uma implementação. No primeiro caso e para implementações simples, ele mesmo providencia a solução e atualiza a versão em uso. Quando a implementação é mais extensa, ela é discutida com os professores envolvidos no projeto para determinar sua prioridade e decidir se será feita de imediato ou entrará na lista de funcionalidades que serão produzidas na próxima fase de implementação.

Apesar do código ser capaz de transmitir sua lógica aos novos desenvolvedores, ele nem sempre explica as razões que levaram a cada escolha na arquitetura e na implementação. A complexidade do projeto mostrou que o conhecimento do histórico de decisões é importante para evitar que alguns problemas fossem rediscutidos sempre que novos desenvolvedores começassem a trabalhar no projeto. Por outro lado, à medida que o projeto cresce, novas necessidades são descobertas e novos requisitos

${ }^{8}$ http://malariadb.ime.usp.br/labd 
precisam ser incorporados. Isso inviabiliza a criação de uma documentação nos moldes tradicionais de desenvolvimento de software pois muito esforço precisaria ser despendido para mantê-los atualizados. A solução foi usar as monografias relacionadas ao projeto como documentação e histórico de decisões. Além disso, uma parcela do conhecimento ficou preservada nos mantenedores e nos professores, pois estas são pessoas ativas no projeto e com baixa chance de se desligarem dele.

Com o tempo, o mantenedor aprofunda seu conhecimento nos detalhes do código e no início das próximas fases de implementação, ele apresenta o código aos novos alunos para acelerar a familiarização com o projeto. O mantenedor ainda ajuda na escolha das próximas tecnologias que serão agregadas ao projeto e acompanha as listas de discussão das disciplinas de LAB-XP e LAB-BD. Enquanto isso, os professores identificam as próximas necessidades e expandem seu conhecimento sobre as regras de negócio.

\subsubsection{Avaliação da Metodologia}

A adoção desta forma de desenvolvimento, baseada em disciplinas semestrais, gerou dois problemas: a falta de pessoas que conheçam bem todos os detalhes do código e a falta de uma equipe fixa, o que exige maior dedicação dos novos grupos que iniciam subprojetos, pois precisam aprender sobre o código das fases precedentes. O primeiro pôde ser abrandado mantendo uma boa documentação no código e fora dele. O segundo foi sanado com a alocação dos alunos de mestrado que acompanham o projeto desde o início e adquiriram um conhecimento amplo sobre cada módulo.

As equipes temporárias foram vantajosas, pois dificilmente estavam desmotivadas, já que trabalharam no projeto por apenas um semestre. Como se trata de um projeto vinculado a uma disciplina, há uma forte cobrança por parte do docente para que a qualidade do software se mantenha elevada. Sobretudo, os alunos sabem que, se não entregarem um software de alto nível, sua avaliação na disciplina estará comprometida.

A forma com que o sistema vem sendo desenvolvido não exigiu novos investimentos da universidade, pois usamos somente recursos já disponíveis. O grande motivo da realização deste projeto foi a união de duas necessidades: a biblioteca precisava de um software e os alunos precisavam de um projeto. O resultado é um sistema que custaria à universidade centenas de milhares de reais.

A arquitetura facilita o uso do banco por desenvolvedores de novos componentes e ingressantes no projeto, pois estes não precisam conhecer detalhes do banco para trabalhar no código dos subsistemas. 


\subsection{No Setor Público - ALESP}

Em 2002, um grande órgão público do Brasil, a Assembléia Legislativa do Estado de São Paulo (ALESP), sentiu a necessidade de informatizar seus departamentos para simplificar os processos internos e tornar o trabalho menos burocrático e mais produtivo. As necessidades que mais urgiam estavam em torno de um sistema de administração de pessoal. A proposta deste sistema foi substituir o trabalho manual realizado no Departamento de Recursos Humanos (DRH), simplificar os processos internos e ainda permear todos os demais departamentos, facilitando a interação entre os funcionários e o DRH.

Motivados pela oportunidade de implantar um sistema inédito em órgãos públicos brasileiros, os funcionários realizaram uma pesquisa sobre as soluções disponíveis no mercado e chegaram à conclusão que nenhuma os atendia completamente devido ao grande número de especificidades. Portanto, a ALESP precisaria de um sistema desenvolvido sob medida pois só assim todos os requisitos seriam atendidos. Nestes casos, a solução mais usada é a terceirização do desenvolvimento. No entanto, a ALESP já havia feito dessa maneira algumas vezes e percebeu que o custo do desenvolvimento era muito elevado, os sistemas entregues apresentavam muitos erros e a baixa qualidade do código ainda dificultava a manutenção. Essas experiências mostraram resultados altamente insatisfatórios, por isso a decisão foi desenvolver internamente com a equipe de tecnologia da própria ALESP.

A complexidade dos processos e o grande número de particularidades motivou a produção do sistema através de um processo tradicional de desenvolvimento. começando pela coleta de todos os requisitos. Contudo, esta abordagem mostrou-se muito lenta e pouco produtiva. Após 18 meses de projeto os resultados foram o levantamento dos requisitos e a produção de uma vasta documentação dos fluxos e processos internos, porém, nenhuma linha de código implementada.

De posse desta documentação, a equipe deveria iniciar a implementação. Porém, além da grande complexidade identificada nos processos, algumas dúvidas mais básicas surgiram: Qual linguagem usar? Por onde começar? Tudo isso dificultou a etapa de transformar a documentação em código e, sem as respostas, o desenvolvimento parou.

Após um período de pesquisas, a equipe da ALESP concluiu que Java seria uma escolha adequada por sua portabilidade, flexibilidade e variedade de tecnologias e arcabouços. Porém, os desenvolvedores não possuíam bons conhecimentos nessa linguagem e nem mesmo em orientação a objetos, uma restrição que tornava a produção do sistema praticamente impossível. 


\subsubsection{Solução: Ajuda Especializada}

Após um longo período sem resultados plausíveis, a equipe percebeu que seria muito difícil produzir o sistema sozinha e partiu em busca do auxílio de profissionais especializados em desenvolvimento de software. A opção mais natural seria a equipe externa criar e entregar o software, mas esta escolha manteria a ALESP dependente da equipe desenvolvedora para evoluir ou realizar manutenção em seu sistema. Por outro lado, a alta complexidade das regras de negócio exigiria um grande esforço de aprendizado por parte de uma equipe externa.

No início de 2005, através de uma parceria com o Instituto de Matemática e Estatística da Universidade de São Paulo (IME-USP), por intermédio da Fundação de Apoio à Universidade de São Paulo (FUSP), uma equipe composta por dois Professores Doutores, dois Mestres e um mestrando em Ciência da Computação, foi composta para conduzir o desenvolvimento. Contudo, considerando os prazos e a complexidade do sistema, a equipe do IME-USP julgou como a solução mais adequada capacitar e orientar a equipe da ALESP durante o desenvolvimento para que ela mesma pudesse produzir o seu sistema. O modelo de auxílio proposto pela equipe do IME-USP se dividiu em duas etapas: na primeira um treinamento em orientação a objetos, em Java e nas tecnologias que seriam usadas para desenvolver o sistema de $\mathrm{RH}$ e, em seguida, o desenvolvimento do sistema de $\mathrm{RH}$ assistido pela equipe do IME-USP. Desta forma, ficaram definidos objetivos de curto, médio e longo prazos:

Curto prazo: treinar um grupo de funcionários, familiarizando-os com uma linguagem orientada a objetos, com as melhores técnicas de programação e com as principais ferramentas usadas para desenvolvimento profissional.

Médio prazo: introduzir uma metodologia de desenvolvimento de software; produzir o software solicitado pela instituição e transmitir a experiência dos especialistas em desenvolvimento de sistemas.

Longo prazo: tornar a equipe de funcionários auto-suficiente, com capacidade de expandir o software criado, desenvolver novos sistemas e disseminar o conhecimento adquirido para outros grupos de funcionários.

\subsubsection{Capacitação em Desenvolvimento}

O objetivo da capacitação foi permitir que a equipe da ALESP (equipeA) adquirisse conhecimento em tecnologias modernas e domínio de uma metodologia de desenvolvimento de software para transformar um grupo de desenvolvimento com dificuldades em apresentar resultados práticos em 
uma equipe capaz de produzir sistemas confiáveis de forma eficiente.

A capacitação aconteceu em duas fases: a etapa de Treinamento e a etapa de Implementação. Na primeira, o objetivo é nivelar e elevar o conhecimento técnico da equipe com a introdução de conceitos e técnicas inerentes a programação orientada a objetos. Na segunda fase, a equipe inicia a implementação do software acompanhada por especialistas em desenvolvimento de sistemas.

O Treinamento foi dividido em três momentos principais: (1) introdução de uma linguagem de programação orientada a objetos; (2) apresentação de arcabouços e ferramentas; e (3) introdução de uma metodologia ágil de desenvolvimento de software.

A etapa de Implementação foi pensada para consolidar o aprendizado da fase anterior, com a equipeA utilizando as técnicas introduzidas na fase de Treinamento para codificar seu sistema com o suporte e orientação da equipe do IME-USP (equipeIME). O objetivo foi a equipeA adquirir experiência prática com boas técnicas de programação e em uma metodologia ágil enquanto participava de um projeto real, produzindo um sistema que seria usado por ela própria no futuro.

A Implementação foi caracterizada pela mescla de duas equipes. A equipeA e a equipeIME passavam a trabalhar juntas no dia-a-dia do desenvolvimento. Todos participavam juntos de todas as etapas da produção do software, desde as reuniões com o cliente até a codificação. Esta estratégia permitiu que a equipeA ganhasse o máximo de experiência a cada dia e que os especialistas acompanhassem de perto e guiassem o andamento do projeto para atingir os objetivos de implementação, prazo e qualidade com sucesso.

\subsubsection{Organização da Equipe}

Os funcionários da ALESP têm seus horários de trabalho distribuídos durante o dia. Alguns membros da equipe começam a trabalhar às $7: 00 \mathrm{~h}$ da manhã e terminam seu turno mais cedo do que outros que chegam mais tarde e saem às 20:00h. Com essa configuração era impossível que a equipeIME estivesse presente em todos os momentos, primeiro porque a dedicação prevista era de 40 horas divididas entre os cinco membros e segundo porque isso seria desperdício de esforços. Desta forma, a equipeIME organizou um esquema de trabalho para dar apoio à equipeA com o máximo de eficiência. Os especialistas do IME se revezavam nas tarefas de instrução e acompanhamento e orientação. A cada dia, conforme as atividades programadas e as especialidades de cada um, um ou dois membros eram selecionados para realizar atividades na ALESP.

Os professores, que possuíam grande experiência com atividades didáticas, foram responsáveis 
pelo maior número de aulas durante a fase de Treinamento. Depois, na Implementação, sua contribuição continuou com orientações na gestão do projeto, através de visitas semanais e com palestras sobre temas mais avançados à medida que a equipeA ia ganhando experiência e maturidade.

Os mestres e o mestrando foram responsáveis por acompanhar o desenvolvimento durante a fase de Implementação, pois eles tinham mais familiaridade com detalhes de programação e com as ferramentas de desenvolvimento. Além disso, algumas aulas e grande parte dos exercícios práticos do Treinamento foram ministrados por eles.

Além das atividades presenciais, após cada dia de visita à ALESP, os especialistas que a haviam realizado enviavam um relatório por e-mail para toda a equipeIME contando os principais avanços e problemas do dia. Esta prática fortaleceu a comunicação e permitiu que no próximo dia aqueles que fossem à ALESP estivessem a par das novidades e muitas vezes já munidos de idéias para solucionar os problemas do dia anterior. Também via e-mail, a equipe discutia possíveis melhorias, idéias para as próximas fases e soluções para os maiores problemas ou dificuldades que surgiam durante o andamento do projeto.

\subsubsection{Treinamento}

O Treinamento durou quatro meses e ofereceu cursos que abrangeram desde os conceitos de orientação a objetos, passando por noções básicas de Java até as ferramentas e tecnologias que permitiriam criar o sistema desejado, incluindo o uso da plataforma de desenvolvimento Eclipse $^{9}$ e de importantes arcabouços de persistência e de desenvolvimento de aplicações web, como Hibernate ${ }^{10}$, Struts $^{11}$ e Velocity ${ }^{12}$. Esta etapa culminou com a apresentação de Programação eXtrema, seguida por um treinamento prático em um projeto piloto, que foi suficiente para deixar a equipe familiarizada e preparada para aplicar a metodologia durante fase de Implementação.

Diariamente, 4 horas de aula ocupavam o período da tarde dos funcionários da ALESP e o restante do expediente era usado para estudo, exercícios práticos e tarefas do dia-a-dia. Cada novo conteúdo era apresentado seguido por uma bateria de exercícios práticos, que auxiliavam na assimilação dos novos conceitos. Parte dos exercícios era realizado durante o treinamento com o acompanhamento da equipeIME, com suporte e orientação personalizada. Esse acompanhamento permitiu identificar os

\footnotetext{
${ }^{9}$ http://www.eclipse.org

${ }^{10}$ http://www . hibernate.org

${ }^{11}$ http://struts.apache.org

${ }^{12}$ http://jakarta.apache.org/velocity
} 
pontos de maior dificuldade no aprendizado, tornando possível que eles fossem reforçados nas aulas seguintes.

Como uma preparação para o aprendizado de XP, alguns de seus principais conceitos foram introduzidos já no início do treinamento. As tarefas de programação foram feitas em duplas desde o primeiro dia de curso. Aos poucos a equipe se adaptou a este modo de trabalho, aprendeu a "pensar em dupla" e a usufruir das vantagens que a programação em pares oferece. A partir do segundo mês de treinamento, a equipeA teve contato com testes automatizados e técnicas para realizar diversos tipos de teste, com atenção especial para testes de unidade [Bin99]. Isso permitiu que a equipeA criasse testes automatizados durante a resolução dos exercícios seguintes de programação.

Periodicamente, mesmo fora do ambiente acadêmico, foram aplicadas avaliações. Essas avaliações foram importantes porque estabeleceram prazos para que a equipe estivesse realmente preparada, estimularam o interesse por minúcias na resolução dos exercícios e ainda permitiram identificar as maiores dificuldades individuais e coletivas. A partir das avaliações também percebemos quando a equipe estava realmente preparada para avançar para a próxima etapa da capacitação e, finalmente, iniciar a construção de seu sistema.

\subsubsection{Implementação Assistida}

Na implementação, da equipeA, participavam 4 programadores com dedicação exclusiva e mais 5 com dedicação parcial. Da equipeIME, diariamente dois membros acompanhavam o desenvolvimento durante meio período cada, variando entre duas configurações de horário, conforme as necessidades de implementação. Ou um dos membros acompanhava o desenvolvimento na parte da manhã e o outro à tarde, ou os dois na parte da tarde. A primeira estratégia favorecia situações onde era preciso oferecer auxílio individual para alguma implementação. Quando os dois estavam no mesmo horário, um deles podia dispensar mais atenção para as duplas com maiores dificuldades enquanto o outro podia circular pelas demais duplas tirando pequenas dúvidas.

O uso de XP provocou grandes mudanças na cultura da equipeA. O treinamento trouxe novos hábitos para a equipe e mais elementos para o ambiente de trabalho. Por volta das 14:30h acontecia uma reunião em pé com todos os presentes (página 42). Cada um dizia rapidamente o que havia feito desde a última reunião, o que pretendia fazer até a próxima e quais dificuldades estava encontrando. Essa prática permitiu principalmente sincronizar as ações da equipe com aqueles com horários de trabalho menos coincidentes. Graças a essas reuniões, os participantes que chegavam de manhã e 
iam embora mais cedo sabiam em que aqueles que chegavam após o almoço estariam trabalhando e vice-versa.

Como os programadores do IME-USP sabiam da heterogeneidade da equipe e tinham consciência de que um dos objetivos era a capacitação da equipe da ALESP, os problemas relatados por Williams [WK02] decorrentes da combinação de programadores de diferentes níveis puderam ser evitados. Para facilitar os momentos em que dois programadores inexperientes pareavam, a escrita dos cartões de histórias foi propositalmente feita com tarefas tão pequenas quanto fosse possível. Assim, a implementação se tornou bastante segmentada e pontual, permitindo que mesmo os programadores novatos pudessem realizá-las criando pequenas porções de código e anexando-as a um núcleo estável sem comprometer o restante do sistema.

A equipeIME ainda cuidou do planejamento do projeto, ajudou a guiar as priorizações de implementação e a tomar decisões de modelagem. Enquanto isso, a equipeA participou ativamente da codificação e acompanhou a gestão do projeto. Após poucos meses ela já era capaz de contribuir com boas sugestões e soluções para questões amplas, de grande impacto para o projeto e para problemas específicos de implementação.

Com o aumento da experiência da equipeA, eles próprios percebiam possíveis melhorias no código que significavam refatorações. Algumas delas não eram triviais, por isso, a cada período de aproximadamente um mês, a equipe sentia necessidade de interromper a criação de novas funcionalidades e reservar alguns dias para refatorações no código. Durante as refatorações, a equipeIME, que também havia ampliado seu entendimento sobre as regras de negócio, tinha a oportunidade de apresentar soluções mais elegantes e sofisticadas de modelagem e arquitetura.

Os papéis de Treinador e Acompanhador foram distribuídos para dois membros da equipeA seguindo um rodízio entre os programadores. Isto permitiu exercitar novas habilidades e aumentar a bagagem de experiência de cada um. A equipeIME pôde conhecer mais sobre os perfis dos membros da ALESP e identificar os mais aderentes a cada papel, facilitando a distribuição das próximas tarefas conforme suas habilidades.

Para manter os bons resultados e adequar o desenvolvimento a fatores que se tornam variáveis, são necessários alguns acertos no processo durante a implementação. Ajustes pequenos são feitos diariamente, porém decisões importantes com maior impacto na implementação requerem reunir as opiniões dos envolvidos e debatê-las a fim de conhecer novos pontos de vista e tomar a decisão que melhor atenda aos requisitos e respeite possíveis restrições tecnológicas ou inerentes às condições de 
trabalho. Aproximadamente a cada dois meses, reuniões com a participação de todos os membros das equipes do IME/USP e da ALESP eram realizadas para fazer uma retrospectiva [Ker01, Coc04] para identificar possíveis melhorias no modo de trabalho, para debater questões técnicas de grande impacto, para propor refatorações que afetariam a arquitetura ou significativamente a modelagem e para discutir a adoção de novas tecnologias.

\subsubsection{Resultados}

Os resultados levam em consideração, após os 11 meses que contribuímos com o projeto, 4 deles na fase de Treinamento e 7 durante a fase de Implementação, o software produzido, a melhoria na capacitação técnica dos funcionários da ALESP e as perspectivas para o futuro do projeto e da equipe.

Após o treinamento, o salto de qualidade técnica na equipeA foi uma unanimidade entre seus participantes. A equipe passou a dominar os conceitos de orientação a objetos e ter conhecimento nas tecnologias necessárias para construir o software que a instituição precisava. A linguagem de programação implantada tornou-se um fator essencial para o trabalho do grupo. Ela proporcionou o aumento da comunicação e do entrosamento entre seus membros. A transferência de conhecimento cresceu naturalmente, dúvidas passaram a ser sanadas internamente com rapidez, as pessoas puderam compartilhar idéias com mais facilidade e passaram a obter soluções melhores para os problemas do dia-a-dia. A introdução de uma metodologia de desenvolvimento foi outro fator que contribuiu para a melhoria da comunicação e ainda unificou o modo de trabalho dentro da equipe, definindo padrões e criando um fluxo conhecido e utilizado por todos.

A convivência entre a equipeIME e a equipeA permitiu uma enorme troca de informações e experiências que foi decisiva para o amadurecimento da equipeA. O processo de capacitação começou no treinamento e continuou durante a implementação com a participação em todas as etapas da produção do sistema. Este envolvimento contribuiu para que a instituição desse seus primeiros passos a caminho da produção autônoma de seus sistemas, pois os maiores conhecedores do código do sistema de RH são os funcionários da ALESP, assim alterações e extensões podem ser feitas internamente.

No início do processo alguns sintomas de insegurança em relação à efetividade da metodologia proposta eram claros em alguns funcionários da ALESP. Devido a fracassos em tentativas anteriores, a tensão e a ansiedade de alguns eram visíveis. À medida que a implementação avançou e os primeiros resultados práticos tornaram-se visíveis, esses sentimentos tornaram-se menores até desaparecerem 
por completo. A introdução da programação em pares, a produção de testes automatizados [Bin99] e a constante realização de refatorações $\left[\mathrm{FBB}^{+} 99\right]$ fez com que a equipe se sentisse motivada e adquirisse confiança no software que produziu.

A mescla entre programadores com grande experiência e iniciantes mostrou ser bastante produtiva. Apesar da falta de experiência com desenvolvimento ágil da equipeA, ótimos resultados foram alcançados desde o início do projeto. Após dois meses de implementação, a apresentação de primeira versão estável do sistema de RH confirmou a eficiência do processo de capacitação. Com seis meses de implementação, o rendimento do trabalho se mostrou em constante crescimento e a versão apresentada à diretoria do DRH causou uma ótima impressão nos escalões superiores da ALESP, que avaliaram o projeto de forma extremamente positiva e aprovaram a renovação da parceria por mais dois anos, expandindo a aplicação da metodologia para outros sistemas do Departamento de Informática.

Os resultados ganharam ainda mais destaque quando comparados com as tentativas anteriores de construção deste software, que sequer alcançaram a fase de implementação, mesmo após quase dois anos de projeto. Portanto, pesando apenas o investimento financeiro, podemos dizer que já alcançamos um resultado substancial. Além disso, convém considerar os benefícios atrelados à melhoria da capacidade técnica dos funcionários, que colocou a equipeA em outro patamar de produtividade.

Após deixarmos de colaborar com o projeto, a equipeA o continuou com auxílio de consultores que atuaram aumentando a força de desenvolvimento por aproximadamente mais dois anos. No final desse período, a diretoria da ALESP foi trocada por dirigentes com interesses diferentes dos anteriores. Com isso, gradativamente, a prioridade do projeto diminuiu e no final de 2007 o desenvolvimento foi oficialmente descontinuado. Mesmo assim, no período entre a nossa saída e o término do projeto, a equipe produziu dois sistemas importantes para a ALESP. Primeiro, implantou os módulos essenciais da folha de pagamento, que eliminou o trabalho manual e repetitivo. Em seguida, o módulo de controle de presença e férias entrou em fase de homologação para simplificar o processo de coleta de dados para a folha de pagamento.

\subsection{Na Indústria - PR\&A}

A PR\&A ${ }^{13}$ é uma empresa cujas especialidades são o apreçamento de ativos non-standard, análise de fundos de investimento, análise de Fundos de Investimentos em Direitos Creditórios (FIDCs),

\footnotetext{
${ }^{13}$ http://www.pra.com.br
} 
consultoria para bancos e empresas de médio porte para a criação e aprimoramento de suas áreas de risco e a criação de softwares de mensuração de riscos de mercado, crédito, liquidez e operacional do setor financeiro. O perfil dos funcionários é dominado por jovens com forte formação na área de exatas, dos quais grande parte são economistas, cientistas da computação, matemáticos e engenheiros. A maior parcela do desenvolvimento de software utiliza como linguagem o C\# e é feito sob a demanda dos contratos, produzindo sempre soluções específicas para cada cliente.

\subsubsection{O Projeto e a Equipe}

No início de 2006, a empresa passou por uma renovação em sua diretoria. Novos sócios passaram a compô-la e uma reestruturação na forma como os projetos de desenvolvimento de software eram conduzidos começou. Uma das metas do novo diretor de tecnologia foi a produção de uma nova versão para um software de análise de ações e fundos de investimento produzido originalmente em Delphi no fim da década de 90. Esta versão apresentava problemas de desempenho e exigia diversas horas de manutenção e suporte técnico. O desenvolvimento de novas funcionalidades havia se tornado insustentável graças a inúmeras dependências obscuras no código. Isso dificultou enormemente a sua expansão e impediu que novos programadores trabalhassem no projeto. Como havia também o interesse de utilizar o sistema pela Internet, a proposta foi produzi-lo novamente, desta vez em Java e para a Web, com todo o escopo de funções da versão anterior, mas com otimizações, correções e todas as novas funcionalidades vislumbradas pelos analistas e diretores da empresa.

Para produzir esse software, um desenvolvedor com experiência com desenvolvimento ágil foi contratado para liderar o projeto. Após a análise do projeto, ele sugeriu a adoção de práticas de $\mathrm{XP}$, de acordo com algumas características que indicaram a compatibilidade entre as condições do projeto e a metodologia:

- O ambiente de trabalho possuía um clima informal e propício para a comunicação verbal.

- Os desenvolvedores tinham interesse em trabalhar com metodologias ágeis.

- Os profissionais das demais áreas estavam dispostos a colaborar e tinham grande interesse no projeto, pois no futuro, o software seria mais uma de suas ferramentas de trabalho.

- Os maiores entendidos sobre as funcionalidades e problemas da versão vigente, assim como das inovações, eram os próprios funcionários das equipes comercial, de suporte e financeira. Isso 
garantia a presença do cliente para esclarecer dúvidas e dar feedback rapidamente durante a implementação.

- Os desenvolvedores possuíam parte do conhecimento sobre o mercado financeiro para a modelagem do comportamento dos ativos e implementação dos cálculos. Isso dispensou o investimento de tempo de profissionais da área financeira para a produção de especificações das funcionalidades. Bastou que eles pudessem dar pequenas explicações sobre detalhes específicos do mercado financeiro.

- A diretoria gostaria de obter resultados rápidos sobre o andamento do projeto para se assegurar de que o desenvolvimento estava no caminho correto e iniciar as atividades comerciais e de marketing.

A equipe era composta por 4 membros, o líder do projeto que realizava atividades de desenvolvimento e de gerenciamento da equipe e mantinha a comunicação com a diretoria e com contatos de fora da empresa, um desenvolvedor com experiência no mercado financeiro, mas inicialmente com pouca prática na linguagem do projeto (Java) e dedicação de $55 \%$ de seu tempo, (45\% de seus dias de trabalho foram dedicados a pequenos projetos sazonais). Os outros dois membros da equipe possuíam conhecimento de Java mas eram estagiários que trabalhavam $25 \%$ menos do que os outros, sendo que um deles só foi integrado à equipe no terceiro mês do projeto. O diretor de tecnologia, um representante comercial e o coordenador do suporte da versão antiga eram os clientes que escreviam cartões de histórias para implementação. Analistas financeiros, economistas e outros funcionários da PR\&A atuaram como usuários com opiniões sobre funcionalidades desejadas, pois iriam utilizar o software em seu trabalho.

\subsubsection{Processo de Desenvolvimento}

O representante comercial também colaborou criando esboços da interface a partir da união da sua experiência nas funcionalidades da versão antiga e o contato direto com os usuários reais (clientes da PR\&A). Inicialmente tentamos utilizar um software específico para desenho de interfaces HTML mas o representante comercial não se adaptou e preferiu produzir os esboços no Excel, mesmo não sendo um software específico para este propósito, mas que se mostrou eficaz pois ele possuía domínio sobre esta ferramenta. As primeiras versões dos esboços eram discutidas com a equipe de desenvolvimento, que por vezes sugeria mais funcionalidades ou as adequava ao ambiente Web. Depois, a interface era apresentada ao diretor de tecnologia, que aprovava o início da implementação. 
Durante o desenvolvimento da primeira versão entregue, a equipe ainda estava incompleta e não possuía domínio de todas as tecnologias que utilizava. Foram necessários dois meses e meio para criar o núcleo do sistema, um novo layout para a interface com a navegação aprimorada e o primeiro conjunto de funcionalidades básicas. Depois, a cada iteração foi desenvolvido um dos módulos do sistema em iterações de duas ou três semanas, conforme a quantidade e a complexidade das tarefas. No fim de cada iteração, as novas funcionalidades eram formalmente demonstradas para os clientes através de uma apresentação onde elas eram aprovadas e sugestões eram coletadas para refinar o produto.

\subsubsection{Práticas Ágeis}

No dia-a-dia do desenvolvimento, diversas práticas de XP foram utilizadas. No entanto, apesar de diversas estudos indicarem as vantagens da programação em pares [WKCJ00, Nos98, CW01], em nossa abordagem pudemos obter diversos de seus benefícios sem realizá-la o tempo todo. Graças ao fortalecimento do valor da comunicação, com uma boa bateria de testes automatizados e a facilidade que o ambiente proporcionava para conseguir auxílio dos companheiros, a equipe adquiriu segurança e sentiu-se confortável para trabalhar individualmente. A programação em pares foi utilizada em cerca de $20 \%$ do tempo, em um formato que passamos a chamar de programação em pares sob demanda. Esta modalidade de programação em aconteceu apenas quando os desenvolvedores sentiam necessidade. Suas principais aplicações foram para: integrar membros à equipe, desenvolver algoritmos complexos e encontrar erros menos óbvios.

A mobília padrão da empresa era de mesas em formato de "L", com divisórias de meia altura que tradicionalmente seriam acomodadas para que seu usuário ficasse voltado para a parede, ou, agrupadas conforme a Figura 3.1.

Optamos por um posicionamento diferente dessas mesas de forma a potencializar o ambiente de desenvolvimento para favorecer a comunicação e a interação entre os membros. Utilizamos as mesmas mesas, mas sem divisórias e dispostas em formato de estrela, com as pessoas voltadas para o centro, assim a participação em conversas e o acompanhamento das atividades do projeto ficou facilitada (Figura 3.2).

Pequenas perguntas sobre o código ou sobre o mercado financeiro eram muito freqüentes e puderam ser resolvidas instantaneamente graças ao posicionamento das estações de trabalho, sem criar interrupções que dispersassem a atenção dos desenvolvedores de suas atividades. Nas paredes ao 


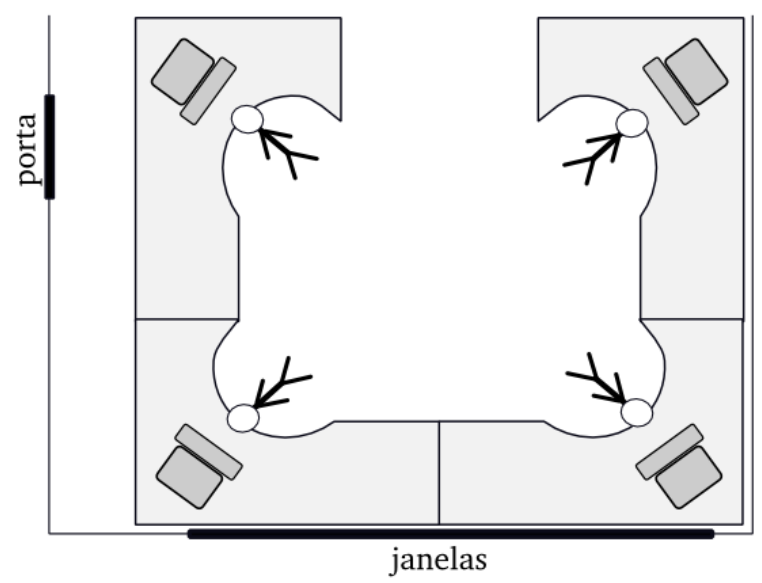

Figura 3.1: Uso tradicional das mesas e do espaço.

redor das mesas foram instalados três quadros brancos que eram usados para pregar os cartões da iteração, para listar refatorações, ajustes e problemas, para manter desenhado um diagrama com as principais classes do sistema e para fazer rascunhos durante as pequenas reuniões diárias da equipe. Ainda nas paredes ficavam cartolinas com gráficos que mostravam a evolução do número de testes e a velocidade da equipe.

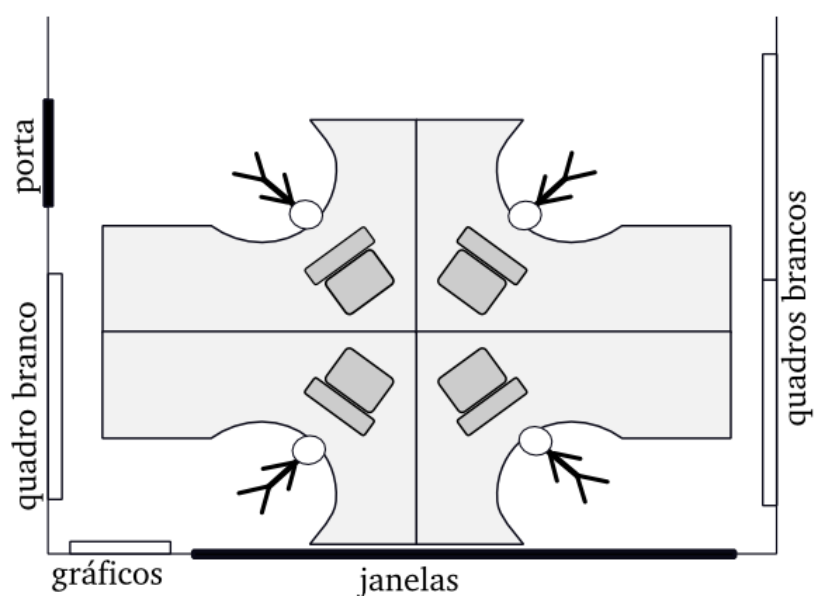

Figura 3.2: Ambiente de desenvolvimento potencializado para comunicação e compartilhamento de informações. 
Periodicamente, a equipe se reunia para discutir a evolução do projeto. Alguns dos encontros tinham o formato de retrospectiva, em outros, batizados de Code Meeting, a equipe se reunia exclusivamente para discutir o código do projeto. Os desenvolvedores que haviam utilizado novas tecnologias demonstravam a organização do novo código e comentavam suas experiências e dificuldades. Os que tinham feito refatorações, ou criado código reutilizável poderiam apresentar essas melhorias e explicar como os outros poderiam tirar proveito disso.

A versão antiga do software foi utilizada para homologar resultados complexos que não podiam ser validados através de ferramentas de testes. Para os outros resultados, a equipe de desenvolvimento se assegurava da corretude dos valores usando testes unitários feitos com o JUnit. Porém, esses testes não eram tão significativos do ponto de vista dos clientes e usuários. Eles já confiavam nos cálculos da versão antiga, então preferiam comparar os resultados da versão nova com a antiga para sentirem-se confortáveis. Em alguns casos, este processo de comparação apontou diferenças que nos levaram a refletir sobre diferentes abordagens, que não eram erradas, mas tratavam alguns elementos de formas conceitualmente diferentes.

Se por um lado a existência da versão antiga do software foi positiva para testes e homologação, por outro tornou-se uma barreira. A interface da aplicação antiga, feita para aplicações desktop, influenciou demais e dificultou o rompimento de alguns paradigmas para a criação de uma interface Web. Inicialmente, as outras áreas eram resistentes às mudanças no modo de navegação e operação do software pois estavam presos aos conceitos de interface utilizados na versão antiga, mas depois concordaram que a nova interface era mais simples e tão poderosa quanto a antiga.

\subsubsection{Conclusão do Projeto}

O desenvolvimento durou 11 meses nos quais a equipe nunca precisou fazer horas extras. Todos os seus integrantes declararam ter aprendido com o projeto e ampliado seus conhecimentos em novas tecnologias, planejamento de projetos, técnicas de desenvolvimento ágil e finanças.

Após 6 meses de desenvolvimento, uma versão beta do software foi disponibilizada em um servidor interno para que os funcionários da PR\&A pudessem usar, acompanhar o desenvolvimento e sugerir melhorias antes que clientes reais tivessem contato com o software. A cada iteração, as funcionalidades aprovadas eram incluídas na versão beta, até que, em janeiro de 2007, uma versão com o escopo necessário para colocar o software no mercado foi fechada. Poucos meses após a entrega desta versão, o sistema foi negociado com uma empresa parceira que também atua no mercado brasileiro 
de análise de fundos de investimento e ações e em meio à negociação, dois dos desenvolvedores da equipe original também foram contratados pela nova dona do projeto.

\subsection{Uma Startup - Ikwa}

Em novembro de 2006, a Ikwa ${ }^{14}$ (http://www. ikwa.com. br) foi a primeira empresa brasileira da geração "Web 2.0" a receber investimento de capital de risco. Seu objetivo foi desenvolver um Web site com ferramentas e conteúdos para auxiliar na orientação, escolha, desenvolvimento, colocação e networking profissional através de um modelo que mescla conteúdo qualificado, produzido por jornalistas, com conteúdo colaborativo, criado pelos usuários.

Diferente da maioria das startups, que são criadas a partir de esforços pessoais e depois lutam para conseguir investimentos, a Ikwa começou na Monashees Capital $+{ }^{15}$, uma empresa de capital de risco que identificou a oportunidade no mercado para criar uma empresa no segmento de orientação profissional. A Monashees buscou três jovens empreendedores dispostos a criar e gerir a Ikwa e reuniu um conselho com quatro profissionais experientes para auxiliar nas decisões importantes e oferecer uma visão ampla sobre a evolução da nova empresa. A partir desse núcleo e de um investimento de capital, mais 15 profissionais e estagiários foram contratados para compor a equipe da Ikwa, sendo 5 de tecnologia, 7 de audiovisual e 3 jornalistas.

Os empreendedores foram escolhidos a dedo por serem, cada um deles, especialista em uma das três áreas fundamentais para o sucesso da empresa: planejamento estratégico, desenvolvimento de sistemas e jornalismo. Os três lideraram a construção da empresa com auxílio da Monashees instituindo um senso de colaboração entre os funcionários e criando um ambiente informal com abertura para opiniões, sugestões e críticas. Somadas essas condições à constante necessidade de adaptação, criou-se um cenário propício para o uso de métodos ágeis.

\subsubsection{Dificuldades de Startups}

Startups operam inicialmente com orçamentos enxutos e buscam investimentos externos para alavancar seus negócios. A partir do momento que conseguem investimentos, precisam apresentar retorno rápido na forma de receita, produtos ou softwares para dar sinais visíveis de progresso e transmitir segurança aos investidores. Muitas vezes é necessário trocar resultados de longo prazo por

\footnotetext{
${ }^{14}$ Ikwa, no dialeto africano Sotho, significa "estar consciente; escutar a si mesmo".

${ }^{15}$ http: //www . monasheescapital . com . br
} 
outros imediatistas, para ganhar fôlego e apresentar avanços que encoragem os investidores a fazer novos aportes. Em fase inicial, startups possuem poucos ou nenhum cliente, por isso usam o investimento recebido para sustentar os custos, tentando manter o burn rate (valor gasto mensalmente) baixo para que seus recursos durem mais e, portanto, tenha mais tempo para alcançar o brake-even (produzir receita suficiente para manter seus custos fixos) e entrar definitivamente no mercado como uma empresa estável.

Empresas da geração "Web 2.0", como é o caso da Ikwa, ainda enfrentam dificuldades por terem seu foco centrado na Internet, pois o desenvolvimento para Web apresenta características que diferem da produção de aplicações convencionais [Hoi03]. Ginige e Murugesan descrevem:

"Sistemas baseados na Web crescem e mudam rapidamente seus requisitos, conteúdo e funcionalidades durante seus ciclos de vida - muito mais do que encontramos normalmente nas engenharias de software, informação e sistemas. O desenvolvimento de sistemas baseados na web é uma atividade contínua sem versões definidas, como acontece com softwares convencionais." [GM01]

Aplicações para a Web têm sempre prazos pequenos devido à velocidade com que a Internet evolui e também porque ela está em operação com centenas de milhões de pessoas navegando diariamente. Este cenário cria a sensação de que a cada dia sem o software, milhares de oportunidades de uso são desperdiçadas. Quando investidores ou idealizadores decidem apostar no desenvolvimento de uma aplicação Web, eles acreditam em seu potencial ou necessidade, portanto, ficam ansiosos por ainda não terem o software. Isso faz com que a equipe de desenvolvimento sofra constante pressão por entregas. Depois de entrar em produção, as correções ou ajustes sempre recebem prioridade altíssima, pois quanto mais tempo um problema demora para ser resolvido, mais pessoas poderão encontrá-lo e, como ele está na Internet, teoricamente qualquer pessoa do mundo pode vê-lo. Embora isso seja verdade, na prática não acontece. Entretanto, essa condição provoca um clima de urgência exagerado e contribui para o aumento da tensão entre a equipe de desenvolvimento e seus clientes.

\subsubsection{Ambiente Colaborativo}

Startups precisam utilizar mecanismos eficientes para divulgar e atualizar informações entre seus membros sem elevar seus gastos ou burocratizar o processo. Documentação física consome tempo para elaboração, exige papel e tinta para ser produzida e fica sujeita a ser perdida ou requer outros recursos 
para manutenção e cópias de segurança. Além disso, produz uma comunicação em apenas uma via: do documento para o leitor, sem a possibilidade de interação. Para evitar essas implicações, o ambiente de trabalho foi pensado para favorecer comunicações verbal e visual. As equipes de desenvolvimento e de jornalistas ficaram reunidas em grandes mesas retangulares no formato de bancadas, que tornava todas as discussões públicas. As duas equipes trabalhavam no mesmo ambiente a apenas alguns metros de distância, com possibilidade de comunicação fácil sempre que preciso. Esta organização favoreceu a colaboração entre as áreas através de explicações e perguntas rápidas sem que fosse preciso produzir qualquer tipo de documentação formal em papel ou em formato eletrônico.

Ao todo, estavam envolvidas 18 pessoas com dedicação exclusiva e 25 considerando conselheiros e investidores. Todas motivadas pela proposta inovadora da empresa e com disposição para contribuir com a construção desta. Com esta grande variedade de sugestões e opiniões, conversas freqüentes pessoalmente e por e-mail foram meios eficientes para identificar oportunidades de melhoria e adaptação à medida que o mercado e os usuários eram melhor compreendidos.

Para acompanhar a evolução do projeto, gráficos e pôsteres, que Cockburn chama de radiadores de informação [Coc06], foram dispostos no ambiente de desenvolvimento para que a equipe monitorasse seu próprio trabalho e identificasse oportunidades de melhoria e visitantes se informassem facilmente sobre o andamento do projeto. Criamos um mural de tarefas e utilizamos quadros brancos e cartolinas para exibir informações relevantes ao projeto conforme sugerido por Beck [BA04], Schwaber [Sch04], Cockburn [Coc06], Sato [Sat07] e, Sharp e Robinson [SR07]. No entanto, como o ambiente não possuía paredes divisórias, tivemos que buscar formas alternativas de publicar informações para os membros da equipe. Em complemento às poucas paredes do ambiente, utilizamos um quadro branco móvel de dupla face (Figura 3.3) e os grandes vidros das janelas como murais de cartões e post-its, como espaços para a fixação de cartazes e como área de rascunho para reuniões em pé [Sch04] e retrospectivas [Ker01].

\subsubsection{Abordagem Ágil}

A grande velocidade com que a tecnologia avança e com que novas aplicações surgem no mercado torna os requisitos cada vez mais instáveis. Boehm chama a incerteza dos usuários no que querem de IKIWISI (I'll know it when I see it) e o desejo por produtos inviáveis de COTS (commercial-off-theshelf) e aponta-os como fatores que também contribuem para a variabilidade dos requisitos [Boe00]. Na Ikwa, a instabilidade dos requisitos chegou a níveis extremos. Outros sites Web 2.0 serviram de inspiração para o seu layout e funcionalidades. Esses sites surgiam ou alteravam suas características 


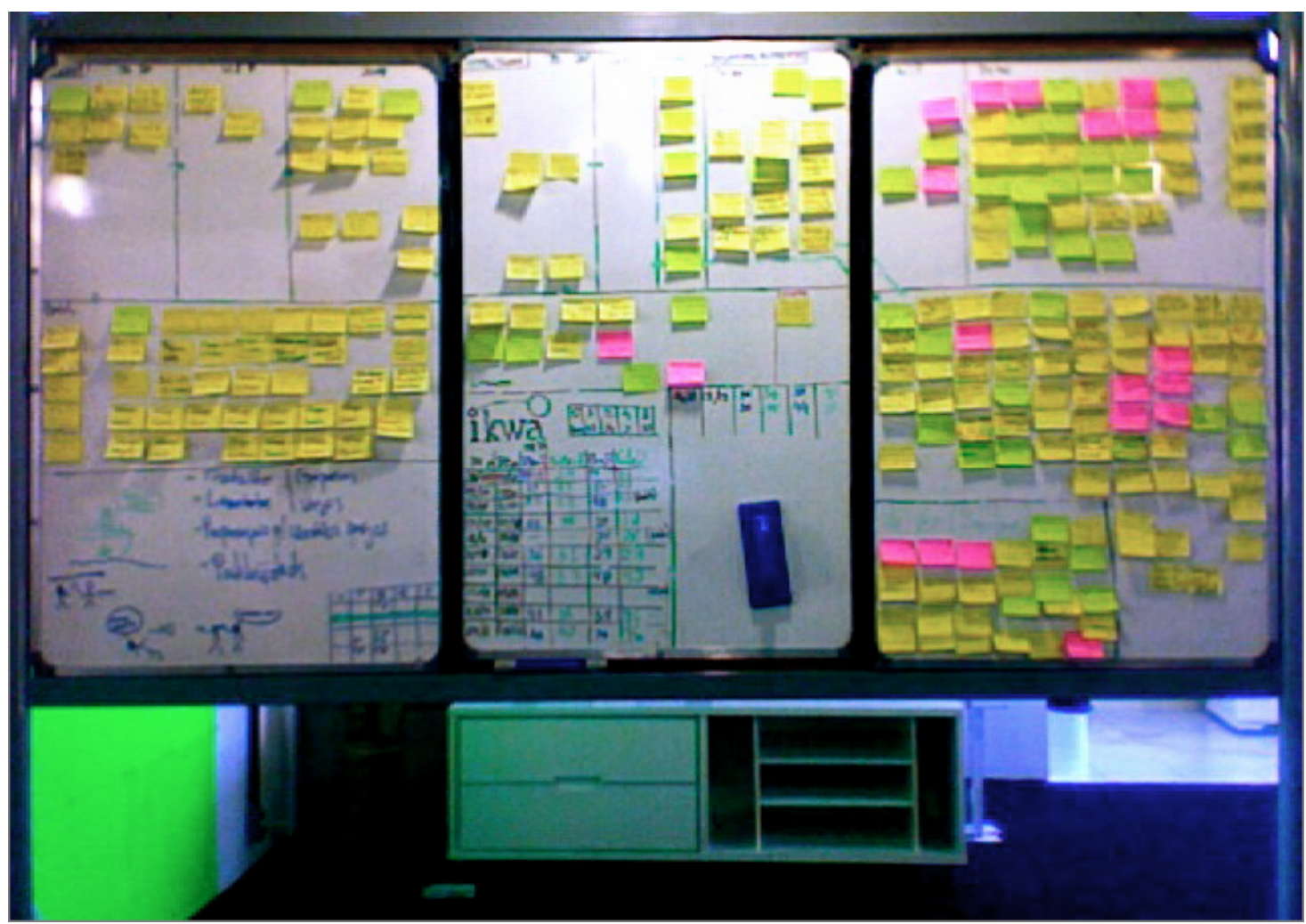

Figura 3.3: Um das faces do quadro móvel com mural de tarefas e alguns rascunhos.

freqüentemente, fazendo com que praticamente diariamente novas influências motivassem melhorias nas funcionalidades e mudanças de prioridade baseadas em adaptações nas estratégias de marketing e comercial.

Para não desperdiçar esforços, startups precisam ser bastante seletivas na escolha de suas atividades. Uma vez definido o objetivo, seus produtos precisam ser criados rapidamente para não perder oportunidades de negócio. Para a equipe de desenvolvimento, isto significa que o foco deve ser colocado em resultados práticos. Portanto, software em produção e produtos com qualidade são muito mais prioritários do que, por exemplo, uma documentação detalhada. Estas características estão de acordo com as premissas do Manifesto Ágil $\left[\mathrm{BBvB}^{+} 01\right]$ e, mesmo antes de sua publicação, Stanley apontava que processos onerosos, tais como CMM [CKS03], não combinavam com startups [Sut00]. Em 2001, Zettel relatou a aplicação com sucesso de métodos ágeis em startups [ZMMW01]. No 
Brasil, o primeiro relato da aplicação de métodos ágeis em startups foi realizado em 2005 por Freire, obtendo bons resultados [FKT05, Fre07]. Apoiados por estes casos, nosso julgamento foi que uma metodologia leve seria a mais adequada para lidar com a alta instabilidade dos requisitos, oferecendo flexibilidade para mudanças e permitindo que resultados pudessem ser alcançados constantemente, com períodos pequenos de desenvolvimento. Optamos por uma abordagem ágil que reuniu conceitos de XP, Scrum, Crystal Clear e Lean para estabelecer um modelo de desenvolvimento adequado às características da Ikwa.

A equipe foi inicialmente embasada com os conceitos dos métodos ágeis através de palestras proferidas pelos dois membros que possuíam larga experiência em desenvolvimento ágil. Para consolidar o aprendizado, as práticas de programação de XP foram exercitadas através de atividades de desenvolvimento nas quais programadores iniciantes interagiram com os experientes e com especialistas em desenvolvimento ágil para construir pequenas aplicações para uso interno em outras áreas da empresa. Após a fase de implantação dos conceitos ágeis e estruturação da equipe, o desenvolvimento do software principal teve início usando a maioria das práticas de XP e algumas de outras metodologias, como desenvolvimento dirigido por testes [Bec03] e retrospectivas [Ker01], com a intenção de selecionar aquelas que mais se adequassem ao projeto.

Passadas algumas semanas foi possível identificar quais práticas trouxeram benefícios à equipe e descartar aquelas que foram tentadas mas não se mostraram valiosas. Algumas características da equipe influenciaram essas escolhas:

- A boa qualidade técnica da equipe e sua autoconfiança fez com que ela se sentisse confortável para não realizar programação em pares constantemente e passar a usar esta prática apenas em situações de maior dificuldade.

- Os cartões inicialmente seguiam o modelo sugerido por Mike Cohn [Coh06] (página 136), porém, gradualmente foram perdendo granularidade à medida que a equipe percebeu a grande instabilidade dos requisitos. Os cartões de história evoluíram para post-its com dimensões um pouco menores e depois para post-its com um quarto do tamanho inicial, aumentando a sua quantidade e a sua especificidade, que além de menores fisicamente, continham tarefas mais curtas que podiam ser concluídas e entregues em menos tempo (antes que o cliente mudasse de idéia).

- Ao fazer iterações mais longas (2 meses), maiores mudanças eram introduzidas na versão atual 
que divergiam das expectativas do cliente. Para mitigar o risco de tais desvios, grandes implementações foram feitas incrementalmente, dividindo-as em pequenas funcionalidades que podiam ser entregues semanalmente e guiavam a implementação das próximas [BA04], evitando o que Gilb chama de big bang delivery [Gil88].

- O ciclo de trabalho foi testado com iterações que variaram desde 1 dia até dois meses e os melhores resultados foram obtidos com iterações pequenas, de até 10 dias. As iterações grandes eram prejudicadas por mudanças de escopo que faziam as estimativas perderem a validade e impediam a equipe de cumprir o planejado. O ponto de equilíbrio foi estabelecido com ciclos de 1 semana que permitiram planejamentos periódicos e davam à equipe a possibilidade de organizar suas atividades.

- O envolvimento de empreendedores, investidores e conselheiros no planejamento estratégico e na definição dos requisitos criou muitos clientes para o sistema e contribuiu para a instabilidade dos requisitos e a mudança de escopo durante a interação. Para diminuir o número de tarefas refeitas, usamos a estratégia de Scrum que sugere ao cliente ter uma só voz [Sch04].

\subsection{Adoção de Práticas}

No início de todos os projetos, selecionamos para cada equipe um conjunto de práticas baseado principalmente nas práticas de XP e, em alguns casos, também nas de Scrum. No entanto, as equipes se adaptaram de formas diferentes a cada uma delas. As características do projeto, o entusiasmo da equipe e os resultados trazidos por cada prática foram os indicadores naturais para mantermos ou substituí-las. As práticas que consideramos essenciais para a qualidade do projeto, como por exemplo, testes automatizados e refatorações no código, insistimos até que a equipe as incorporasse em sua cultura. Para outras, como por exemplo, a atualização diária de gráficos, tentamos não influenciar demais para que a equipe pudesse sentir a necessidade de realizá-las. Durante o projeto, à medida que percebemos necessidades ou oportunidades para melhoria, incluímos práticas propostas por nós (descritas no Capítulo 4) ou originárias de outras metodologias ágeis.

Na Tabela 3.2 apresentamos as práticas oriundas de metodologias ágeis que empregamos nos quatro casos que descrevemos ${ }^{16}$. Esta tabela evidencia a singularidade de cada caso, proporcionada pela combinação entre as características do projeto e da equipe. O símbolo $\sqrt{ }$ indica que ela foi

\footnotetext{
${ }^{16}$ Como reunimos práticas de diversas metodologias, excluímos práticas equivalentes de metodologias diferentes que diferem apenas no nome, nestes casos apresentamos apenas uma delas.
} 
implementada completamente, o que significa que todos os membros a praticaram regularmente durante o período em que a equipe se propôs; o símbolo • indica que a prática foi usada em tempo parcial, ou por apenas uma parte da equipe; e o símbolo o aponta que a prática não foi adotada. 


\begin{tabular}{lcccc}
\hline Prática & Colméia & PR\&A & IKWA & ALESP \\
\hline Sentar Junto & $\sqrt{ }$ & $\bullet$ & $\bullet$ & $\sqrt{ }$ \\
\hline Área de Trabalho Informativa & $\sqrt{ }$ & $\sqrt{ }$ & $\sqrt{ }$ & $\sqrt{ }$ \\
\hline Histórias & $\sqrt{ }$ & $\sqrt{ }$ & $\sqrt{ }$ & $\sqrt{ }$ \\
\hline Ciclo Semanal & $\sqrt{ }$ & $\sqrt{ }$ & $\sqrt{ }$ & $\bullet$ \\
\hline Ciclo Trimestral & $\sqrt{ }$ & $\sqrt{ }$ & $\bullet$ & $\sqrt{ }$ \\
\hline Folga & $\sqrt{ }$ & $\sqrt{ }$ & $\sqrt{ }$ & $\sqrt{ }$ \\
\hline Build Ágil & $\sqrt{ }$ & $\sqrt{ }$ & $\sqrt{ }$ & $\sqrt{ }$ \\
\hline Design Incremental & $\sqrt{ }$ & $\sqrt{ }$ & $\sqrt{ }$ & $\sqrt{ }$ \\
\hline Trabalho Energizado & $\sqrt{ }$ & $\sqrt{ }$ & $\bullet$ & $\sqrt{ }$ \\
\hline Desenvolvimento Dirigido por Testes & $\bullet$ & $\bullet$ & $\bullet$ & $\bullet$ \\
\hline Código Compartilhado & $\sqrt{ }$ & $\sqrt{ }$ & $\sqrt{ }$ & $\sqrt{ }$ \\
\hline Envolvimento Real com o Cliente & $\sqrt{ }$ & $\sqrt{ }$ & $\sqrt{ }$ & $\sqrt{ }$ \\
\hline Padrões de Código & $\sqrt{ }$ & $\sqrt{ }$ & $\sqrt{ }$ & $\sqrt{ }$ \\
\hline Implantação Incremental & $\sqrt{ }$ & $\sqrt{ }$ & $\sqrt{ }$ & $\circ$ \\
\hline Testes Automatizados & $\sqrt{ }$ & $\sqrt{ }$ & $\sqrt{ }$ & $\sqrt{ }$ \\
\hline Repositório de Código Unificado & $\sqrt{ }$ & $\sqrt{ }$ & $\sqrt{ }$ & $\sqrt{ }$ \\
\hline Implantação Diária & $\circ$ & $\circ$ & $\bullet$ & $\circ$ \\
\hline Refatoração & $\sqrt{ }$ & $\sqrt{ }$ & $\sqrt{ }$ & $\sqrt{ }$ \\
\hline Identifique os Envolvidos & $\sqrt{ }$ & $\sqrt{ }$ & $\sqrt{ }$ & $\sqrt{ }$ \\
\hline Mitigação de Riscos & $\bullet$ & $\sqrt{ }$ & $\sqrt{ }$ & $\circ$ \\
\hline Evolução do Planejamento & $\bullet$ & $\sqrt{ }$ & $\sqrt{ }$ & $\sqrt{ }$ \\
\hline Modelagem de Domínio de Objetos & $\bullet$ & $\sqrt{ }$ & $\sqrt{ }$ & $\bullet$ \\
\hline Desenvolvimento por Funcionalidade & $\bullet$ & $\sqrt{ }$ & $\bullet$ & $\bullet$ \\
\hline Exploração de 360 & $\bullet$ & $\sqrt{ }$ & $\sqrt{ }$ & $\sqrt{ }$ \\
\hline Esqueleto que Anda & $\bullet$ & $\sqrt{ }$ & $\bullet$ \\
\hline Retrospectiva & $\bullet$ & $\sqrt{ }$ & $\sqrt{ }$ \\
\hline Reunião em Pé & $\bullet$ & $\sqrt{ }$ & $\sqrt{ }$ \\
\hline Presença de ScrumMaster & $\bullet$ & $\sqrt{ }$ & $\circ$ \\
\hline Presença de Coach & $\bullet$ & & $\sqrt{ }$ \\
\hline Programação lado a lado & $\bullet$ & $\sqrt{ }$ & $\circ$ \\
\hline Burn Down Charts & $\bullet$ & & \\
\hline Outros Radiadores de Informação & $\bullet$ & & \\
\hline & $\bullet$ & & \\
\hline
\end{tabular}

Tabela 3.2: Uso de práticas ágeis durante os projetos que estudamos. 


\section{Capítulo 4}

\section{Práticas Ágeis}

A necessidade de resultados rápidos e expressivos motivou a busca por maneiras mais eficientes de aproveitar os recursos, as habilidades e o conhecimento, seja ele técnico, tácito, tático ou gerencial. Neste capítulo, apresentamos práticas que utilizamos durante os projetos descritos no Capítulo 3 e as conclusões que chegamos baseados nas metodologias que apresentamos no Capítulo 2, nas principais referências da literatura e na experiência que adquirimos após vários anos trabalhando com desenvolvimento ágil.

Recomendamos as práticas que reunimos neste capítulo para equipes pequenas, formadas por até 14 pessoas, não exclusivamente adeptas de desenvolvimento ágil. Extraímos essas práticas de casos de sucesso que obtivemos, por isso as classificamos como "boas práticas" que podem ser usadas isoladamente, independentemente do contexto do projeto. Contudo, sugerimos que cada projeto tenha um conjunto específico de práticas, escolhidas pela equipe e por seu líder de acordo com o seu perfil e com as características do projeto.

Algumas das práticas foram usadas durante todo o ciclo dos projetos que descrevemos, outras em momentos pontuais. Realizamos, em caráter experimental, diversas variações de práticas conhecidas na literatura com o objetivo de aumentar a qualidade do software desenvolvido, a produtividade da equipe, a satisfação dos clientes ou a motivação dos desenvolvedores. As percepções que obtivemos são apresentadas a seguir, agrupadas nas categorias estratégica, motivacional e de desempenho.

\subsection{Práticas Estratégicas}

Classificamos como estratégicas as práticas que ajudam na organização da equipe considerando valores não exclusivamente relacionados ao seu conhecimento técnico. Entre os principais aspectos que 
essas práticas se propõem a reforçar, estão a organização, a distribuição e o melhor aproveitamento do conhecimento dentro da equipe.

\subsubsection{Tripé de Conhecimentos - Alesp Colméia PR\&A Ikwa ${ }^{1}$}

As principais referências da Engenharia de Software destacam a participação de desenvolvedores, analistas de negócios, usuários e outros tipos de colaboradores na construção de sistemas [Kru03, Pre04,BA04,Coc06,Sch04,Som06]. Compilando as habilidades dos envolvidos, percebemos que a produção de sistemas complexos depende essencialmente de três ingredientes: conhecimento técnico, visão de negócios e vivência com o problema. Portanto, ao invés de estabelecer papéis dentro da metodologia para serem incorporados ou preenchidos, é interessante identificar quem são os detentores desses três tipos de conhecimento e garantir que eles tenham a medida certa de envolvimento no projeto.

Os três tipos de conhecimento geralmente não estão presentes nas mesmas pessoas. O primeiro concentra-se na equipe de desenvolvimento, o segundo nos empreendedores que identificam necessidades e o terceiro em usuários que convivem com o problema e conhecem as minúcias operacionais.

A falta ou desproporção de algum dos elementos desse tripé implicará dificuldades para o projeto. A ausência de conhecimento técnico inviabiliza ou atrasa a criação do software. Falta de visão de negócios torna o desenvolvimento desnorteado, sem capacidade para identificar as prioridades. Enquanto a falta de vivência com o problema faz com que o software tenha funcionalidades pouco úteis ou que não motivam o usuário a usá-lo.

As três frentes devem ser consideradas para conduzir o desenvolvimento unidas. $\mathrm{O}$ controle desproporcional desperdiçará esforços sem obter o melhor aproveitamento das atividades de desenvolvimento. Kent Beck aponta conseqüências da desproporção de controle entre responsabilidades técnicas e de negócios. Quando a equipe técnica toma as decisões, o desenvolvimento pode enviesar por inúmeras tecnologias, ferramentas e processos que aumentam o risco e tiram o foco das prioridades de desenvolvimento [Bec99]. O controle total pela equipe de negócios provoca excesso de requisitos e pouca priorização aumentando o custo e o risco de desenvolvimento. O controle nas mãos dos usuários acontece quando as equipes técnica e de negócios transformam todas as opiniões dos usuários em requisitos. A conseqüência é a explosão do número de requisitos e o surgimento

\footnotetext{
${ }^{1}$ Para aumentar a contextualização das práticas, referenciamos no início de cada uma os projetos onde elas foram exercitadas.
} 
de requisitos conflitantes e mutantes. Todos essas funcionalidades atendem a interesses de usuários específicos mas não consideram valor de negócio nem dificuldades de implementação.

Em um cenário ideal, as opiniões de usuários são analisadas pelas equipes técnicas e de negócios para identificar sua relevância, valor de negócios, custo, dificuldade e risco de implementação. Sugestões vindas da equipe de negócios são validadas com usuários e estimadas pela equipe técnica e, necessidades e restrições técnicas são analisadas e negociadas com a equipe de negócios.

Dois erros comuns são: 1) supor que a equipe técnica possui ou irá adquirir rapidamente a vivência com o problema e, 2) misturar vivência com o problema com visão de negócios.

Para evitar o primeiro, é importante perceber que equipes de desenvolvimento dominam detalhes técnicos e têm facilidade para lidar com regras que estão claramente delineadas. Contudo, muitos sistemas lidam com regras pouco definidas, muito dispersas ou que estão armazenadas na forma de conhecimento tácito, dificultando e retardando o seu aprendizado. Nestes casos, é fundamental que pessoas especializadas acompanhem o desenvolvimento. Esta estratégia foi usada na ALESP ao manter a equipe de funcionários - que domina as regras de negócio - trabalhando junto com os desenvolvedores experientes. No Colméia, aumentamos o número de funcionários da biblioteca envolvidos com o projeto para oferecer mais suporte aos desenvolvedores e evitar que eles fizessem suposições ou simplificações das regras de negócio.

A mistura da visão de negócios com a vivência do problema acontece quando a equipe de desenvolvimento não reconhece quem exerce cada um desses papéis. O papel da equipe de negócios é definir as prioridades e selecionar as funcionalidades, sem assumir muitos detalhes minuciosos. Os detalhes podem ser fornecidos pelos usuários para que as equipes de negócios e de desenvolvimento os usem para auxiliar suas decisões. No Colméia, esta separação ficou clara através do envolvimento do presidente da biblioteca no papel de cliente, responsável pela visão de negócios, uma vez que ele compreende as necessidades da biblioteca e é responsável por tomar as decisões, porém não domina os detalhes operacionais do dia-a-dia da biblioteca. Os funcionários da biblioteca atuaram como usuários, fornecendo suas experiências com a vivência do problema. Eles descreveram suas atividades e os detalhes operacionais que poderiam ser criados para aumentar a usabilidade do sistema. Nas vezes em que os funcionários tiveram dificuldade de fornecer respostas precisas sobre a lógica de seus processos, o presidente, com uma visão mais ampla, auxiliava a abstrair essa lógica e a simplificar os processos.

Na Ikwa, o papel referente aos usuários muitas vezes era assumido pela equipe de negócios, porém 
esse foi um problema inerente à natureza do software, que ainda não possuía usuários. Para lidar com essa dificuldade, a equipe de negócios constantemente buscava evidências que indicassem as melhores decisões através da pesquisa de casos de sucesso, tendências da web, conversas com pessoas com perfil de usuário e o oferecimento de acesso a uma versão beta do software para colher feedback de usuários.

\subsubsection{Acoplamento ao Cliente $\quad-$ Alesp Colméia PR\&A Ikwa}

$\mathrm{XP}$ recomenda que o cliente esteja presente durante o desenvolvimento [BA04], Crystal sugere identificar e envolver as pessoas certas para ajudar a identificar e definir as necessidades do projeto [Coc04] e FDD e Scrum recomendam fazer reuniões onde as funcionalidades são detalhadas diretamente aos desenvolvedores [PF02, Sch04]. Essas evidências mostram a intenção de envolver clientes, usuários e desenvolvedores para que a equipe técnica tenha acesso às informações que irão determinar as características do software. Porém, dependendo da maneira como este conhecimento está armazenado e de sua clareza, transferi-lo aos programadores pode ser um processo simples ou lento. Por isso, é válido avaliar a dificuldade das regras de negócio para definir o acoplamento adequado entre clientes, desenvolvedores e usuários.

Nem sempre mais acoplamento é melhor. Quando as regras de negócio estão claras, o desenvolvedor precisa apenas de tempo para implementá-las [DL99]. Neste caso, a presença de clientes não colaborará e pode ser dispensada, ao menos parcialmente. Identificar esses casos evita desperdício com mais envolvidos do que o projeto requer. Por outro lado, para casos que possuem regras de negócio complicadas ou difusas, ao invés de tentar transferir o conhecimento, o desenvolvimento avança mais rápido quando as pessoas que já compreendem essas regras trabalham juntas com os programadores.

Portanto, percebemos que conforme as características de suas regras de negócio e o número de exceções que elas possuem, o projeto requer um nível específico de acoplamento com o cliente. Utilizamos diversos graus de acoplamento entre clientes e desenvolvedores para identificar o envolvimento ideal do cliente em cada projeto. Assim, evitamos o subaproveitamento das pessoas de negócios em projetos menos críticos, permitindo que desde o planejamento elas sejam alocadas parcialmente e fiquem liberadas para outras tarefas no tempo restante.

Quando as regras de negócio são bem definidas e seguem uma estrutura lógica, o acoplamento com o cliente pode ser baixo. No projeto da PR\&A, apesar do sistema possuir uma grande complexidade 
devido a cálculos financeiros, suas regras possuíam poucas exceções. A equipe de desenvolvimento teve facilidade para absorver os conceitos e foi capaz de desenvolver a aplicação fazendo consultas pontuais aos especialistas da área financeira sem precisar alocar um deles especificamente para o projeto.

Na ALESP, a implementação exigiu apenas cálculos simples, porém ela seria impossível sem o contato intenso com os funcionários da instituição. Por exemplo, para calcular os valores salariais dos servidores públicos, precisam ser consideradas a legislação trabalhista pública atual junto com suas versões anteriores, pois elas regulam os direitos adquiridos no decorrer das carreiras dos funcionários. Portanto, como as regras de negócios estão associadas a um grande número de casos particulares, a participação de especialistas para determinar quando cada lei se torna aplicável foi essencial e o acoplamento com o cliente precisou ser alto.

No Colméia, apesar de muitas das funcionalidades serem simples, o sistema também realiza operações administrativas desconhecidas dos alunos que mesmo os funcionários tinham certa dificuldade em explicar a sua lógica e em identificar generalizações ou casos particulares dos processos que realizavam manualmente. Começamos com um acoplamento baixo que cresceu à medida que os casos excepcionais mostraram-se mais numerosos. Primeiramente, apenas o presidente da biblioteca acompanhava o desenvolvimento com visitas semanais ao laboratório e, esporadicamente, alguns funcionários eram convocados para explicar suas atividades ao programadores. Depois, aumentamos o acoplamento para médio com o envolvimento de mais funcionários da biblioteca. As visitas dos funcionários passaram a ser mais freqüentes, os desenvolvedores foram à biblioteca entrevistá-los e um desenvolvedor da biblioteca passou a acompanhar e dar suporte semanalmente durante as aulas no laboratório e por e-mail.

Já na Ikwa, as regras de negócio não estavam definidas, pois tratava-se de um produto em concepção e, portanto, em fase de constante evolução. Não havia usuários, então os programadores tinham a liberdade para contribuir com a definição do produto final, lapidando os detalhes das funcionalidades. Neste caso, o ideal foi um acoplamento médio. Foi importante fazer reuniões freqüentes para reunir idéias e definir os próximos passos da implementação, sem que os clientes precisassem permanecer juntos com os desenvolvedores todo o tempo. As maiores questões eram referentes ao layout da interface do usuário. Em média, duas vezes por semana versões de rascunho eram enviadas por e-mail para os envolvidos e a versão final era produzida considerando suas sugestões.

Para os projetos da PR\&A, ALESP e Colméia o fator determinante para o grau de acoplamento 
foi a quantidade de exceções às suas regras. No caso da Ikwa, o que mais exigiu contato com o cliente foi a definição da interface de usuário e a priorização de funcionalidades.

\subsubsection{Nivelamento de Equipes - Alesp Colméia PR\&A Ikwa}

A composição de equipes de desenvolvimento nem sempre segue o conceito de equipes completas e auto-suficientes recomendada por XP e Scrum [BA04, Sch04], entre outras metodologias. A constituição da equipe pode contribuir para parte das dificuldades encontradas durante a produção do software. Quando os membros possuem perfis muito similares, algumas habilidades podem ficar ausentes e as soluções propostas são baseadas em menos pontos de vista, o que para XP não é bom, pois vai contra o princípio da diversidade (página 52). Por outro lado, pessoas com culturas profissionais radicalmente diferentes terão mais dificuldades na comunicação e para estabelecer um fluxo contínuo de trabalho.

Para instituições públicas e órgãos do governo, a dificuldade na produção de sistemas cresce devido à forma como seus profissionais são selecionados: nestas instituições, a seleção acontece através de concurso público. Equipes formadas dessa maneira contarão com os melhores profissionais na avaliação geral, porém não há garantia de que o grupo tenha imediatamente todas as habilidades que necessita.

Na ALESP, percebemos que funcionários contratados a partir de concursos têm formações radicalmente diversas, modos de trabalho diferentes e experiências em linguagens de programação variadas. Essa diversidade enriquece a equipe com muitas culturas e experiências, porém, a falta de uma linguagem de programação comum cria uma forte barreira para a comunicação e a colaboração no trabalho. Além disso, a ausência de uma metodologia de desenvolvimento promove o individualismo. Como conseqüência, cada profissional trabalha independentemente, usando suas próprias ferramentas, com pouca comunicação e compartilhamento de conhecimento.

Consideramos as deficiências iniciais da equipe da ALESP como críticas para o sucesso do projeto. Por isso, antes de começar o desenvolvimento, julgamos ser imperativo eliminá-las. Realizamos um período de treinamento, onde criamos uma base de conhecimento comum a todos os envolvidos. Após este período de nivelamento, a equipe adquiriu o conhecimento necessário em uma linguagem de programação, nas tecnologias e na metodologia de trabalho para produzir um sistema de grande porte. Com este conhecimento, barreiras de comunicação foram superadas e o número de atividades colaborativas cresceu expressivamente. 
No projeto Colméia, a formação da equipe aconteceu sem que os professores e clientes influenciassem na seleção dos desenvolvedores. Qualquer aluno do curso de computação da graduação (em geral do $3^{\mathrm{O}}$ ou $4^{\mathrm{O}}$ ano) ou da pós-graduação poderia se inscrever, limitados simplesmente ao número de vagas disponíveis na disciplina. Dentre os matriculados, cada um poderia escolher o projeto de que gostaria de participar.

Neste caso, todos tinham formações parecidas e muitos se conheciam, o que eliminou barreiras de comunicação e colaboração. Porém, a maioria não possuía experiência com desenvolvimento em equipes, nunca havia desenvolvido um sistema com usuários e clientes reais e ainda não tinha consolidado diversos dos conceitos que aprendera recentemente na universidade.

Tais fatores demonstravam a presença de lacunas no conjunto de habilidades da equipe. Para colocar todos no mesmo patamar de conhecimento, as aulas ministradas antes da etapa prática da disciplina serviram para apresentar ou reforçar conceitos básicos e necessários para o desenvolvimento de sistemas. Os principais temas abordados durante as aulas de nivelamento incluíram a apresentação dos conceitos de XP e de suas práticas, passando por testes automatizados e refatorações e esbarrando em revisões de boas práticas de orientação a objetos. Durante as aulas de laboratório, a programação em pares ajudou a concluir o nivelamento. Os pares discutiam sobre suas estratégias de implementação e aprendiam juntos sobre o sistema e sobre as tecnologias que usavam. Como conseqüência, os alunos mais adiantados explicavam e ajudavam os iniciantes. O mesmo comportamento colaborativo ocorreu durante a fase de Implementação no projeto da ALESP entre consultores e funcionários e entre os próprios funcionários.

Quando equipes são formadas ou quando novos membros passam a integrá-la, recomendamos o nivelamento do conhecimento para que todos possuam a base de conceitos essenciais para o projeto, tais como tecnologias, processos, regras de negócio e uma visão geral do que foi produzido. Para equipes em formação, o nivelamento pode ser estabelecido através de um treinamento com as principais tecnologias e com a definição de uma metodologia de trabalho adequada ao projeto e à equipe. Quando novos membros juntam-se à equipe, o acesso ao código do sistema com exemplos das principais atividades e o acesso fácil e simplificado às principais regras de negócio o ajudarão a absorver rapidamente o conhecimento necessário para, mesmo sem conhecer os detalhes do projeto, acompanhar o resto da equipe. De posse desse conhecimento essencial, a programação em pares irá facilitar a compreensão das atividades da metodologia e servirá para a absorção de detalhes do código. Opcionalmente, a aquisição do conhecimento básico também pode ser feita em par com um membro experiente. 


\subsubsection{Barreira de Entrada $\quad-\quad$ Alesp $\quad$ PR\&A Ikwa}

Programadores sem experiência em ambientes empresariais precisam se adaptar ao modo de trabalho usado pela empresa. Para contribuírem no projeto que atuam, precisam aprender tecnologias e se familiarizar com o código que já existe. A curva de aprendizado associada a esses fatores torna-se uma barreira de entrada para novos membros se estabelecerem na equipe. Além disso, esta barreira cresce quando o indivíduo ainda precisa se adaptar a processos e a formalidades do desenvolvimento.

Da mesma maneira, quando uma metodologia é introduzida, os antigos hábitos de trabalho são modificados e a adaptação às novas práticas também pode ser considerada uma barreira de entrada para que a equipe atinja a produtividades desejada. Freire sugere padrões para o ensino de XP, aplicáveis em situações específicas [Fre07], já nossa abordagem limita-se a oferecer uma visão e solução gerais para o problema.

Uma forma de reduzir essa barreira para novos participantes é exigir que eles aprendam o mínimo de regras para acompanhar o restante da equipe. Com metodologias leves e a apresentação das práticas, gradativamente, o ambiente de trabalho fica menos formal e mais próximo dos que os iniciantes estão acostumados a conviver.

As equipes com quem trabalhamos possuíam uma grande parcela de integrantes novatos. Com elas o uso de pouca formalidade e introdução gradual das práticas ágeis fez com que os membros se adaptassem mais rápido do que aqueles que foram expostos a todas as práticas de uma só vez. Novos membros foram integrados começando pela programação em pares para que aprendessem as práticas com ajuda de um membro mais experiente.

Karlsson e Åhlströn recomendam, para a implantação de desenvolvimento Lean, que a equipe tenha consciência e aceite as mudanças e que o processo de transição seja suave [KA96]. Nossas conclusões são de que é possível introduzir uma metodologia ágil na cultura de uma equipe mesmo que ela não esteja completamente disposta a aceitar a mudança. Para isso, concordamos que a transição deve ser gradual e estendemos essas conclusões para equipes que não podem parar sua produção. Mudando os hábitos de desenvolvimento um a um, a equipe não sente um choque porque realiza uma transição suave onde pode perceber quais práticas lhe trazem mais benefícios e manterse confiante e motivada. Confiante porque, com pequenas mudanças, os indivíduos continuarão conhecedores do processo geral e motivada porque suas opiniões poderão ser consideradas durante a fase de migração, sem a sensação de que sua cultura de trabalho foi suprimida. 


\subsubsection{Combatendo a Resistência Interna - Alesp Colméia PR\&A Ikwa}

Quando uma metodologia ágil é introduzida, uma etapa importante para o seu sucesso é o convencimento e a motivação da equipe em relação a esta mudança, pois pessoas que trabalham em algo que acreditam, tendem a produzir resultados melhores. Porém, para programadores acostumados com metodologias tradicionais, as práticas usadas em metodologias ágeis trazem hábitos muito diferentes dos que estão acostumados em seus empregos, por isso torna-se difícil confiar que a mudança será vantajosa.

Nossa experiência indica mais facilidade no ensino de métodos ágeis para programadores inexperientes. Desenvolvedores experientes, mas sem hábitos ágeis, tendem a resistir a mudanças para metodologias mais leves. Propriedade coletiva do código, desenvolvimento dirigido por testes (TDD) e programação em pares são as práticas que mais causam estranhamento e geram resistência porque os programadores precisam mudar drasticamente suas formas de trabalhar $\left[\mathrm{SBB}^{+} 06\right]$. Para esses programadores, a propriedade coletiva traz o receio de que pessoas menos experientes modifiquem o código e introduzam erros. Defendemos essa prática mostrando que esse problema é evitado quando existe um conjunto de testes automatizados que cobre adequadamente o código e a equipe adquire o hábito de executá-lo freqüentemente. A programação em pares incomoda profissionais com o costume de trabalhar sozinhos. Williams e Kessler identificam mitos e sinergias relacionados à programação em pares e possíveis efeitos colaterais decorrentes dos perfis dos membros da dupla [WK02]. Na ALESP, introduzimos a programação em pares em equipes compostas por uma parcela de membros experientes neutralizando esses sintomas a partir da conscientização prévia dos benefícios para o projeto e para os indivíduos através de palestras e exercícios de programação em dupla. Depois, combinando potenciais programadores resistentes com programadores experientes em desenvolvimento ágil e em programação em pares para que os primeiros pudessem aprender e perceber os benefícios através de uma experiência positiva com essa prática. O TDD causa resistência porque fazer testes antes e junto com a implementação conflita com a cultura do desenvolvimento tradicional, que segmenta a produção do software em etapas distintas. Conseguimos mostrar os valores dessa prática também através de palestras introdutórias e exercícios de programação que aumentavam a confiança no código com a produção de testes desde o início.

Observamos ainda que, para desvencilhar os programadores de comportamentos individualistas que impedem a assimilação das práticas ágeis, foi importante ressaltar dois pontos: 1) quando a equipe consegue sinergia, alcança resultados mais expressivos e 2) equipes ágeis são medidas por 
resultados e não por horas trabalhadas. Baseado nisso, os resultados do grupo são mais importantes do que conquistas pessoais.

As próximas práticas tratam a resistência gerada por indivíduos de fora da equipe quando métodos ágeis são introduzidos.

\subsubsection{Combatendo a Resistência Externa - Alesp PR\&A Ikwa}

A introdução de uma metodologia ágil pode sofrer rejeição por parte de pessoas de fora da equipe em empresas onde o desenvolvimento tradicional predomina. A falta de informação sobre métodos ágeis pode fazer com que eles sejam vistos de forma preconceituosa, gerando críticas sobre falta de planejamento, falta de organização e etapas pouco definidas no processo. Mesmo fora da equipe, esse tipo de visão coloca em dúvida a qualidade do software e a certeza da entrega para aqueles que ainda não conhecem metodologias ágeis, impondo obstáculos para a implantação de novas metodologia e filosofia de trabalho.

Mostrar as vantagens e os objetivos do desenvolvimento ágil pode evitar que pessoas de fora da equipe façam interpretações distorcidas e tornem-se opositoras. Ao invés disso, elas podem se tornar interessadas em métodos ágeis, aumentando as chances de sucesso, pois mais interessados e colaboradores poderão contribuir com o processo de implantação.

Uma forma amigável de mostrar os valores ágeis é colaborando com equipes que não utilizam essas práticas, para que juntas, ambas as equipes consigam resultados melhores. Conhecendo outro processo de desenvolvimento, a implantação pode evitar problemas já vivenciados. Em troca, algumas práticas ágeis podem ser sugeridas de forma avulsa para as equipes que usam processos tradicionais, como alternativas para as atividades onde elas encontram mais dificuldades.

Outra forma de promover a colaboração entre equipes é o compartilhamento de conhecimento técnico, pois alguns assuntos são de interesse comum, independentemente do tipo de processo de desenvolvimento utilizado. Reuniões informais que visam a discutir melhoria da qualidade do código, estratégias para realizar testes automatizados, refatorações, padrões de projeto, técnicas de otimização, novos arcabouços e experiências anteriores com tecnologias específicas são formas de estabelecer contato entre as equipes. Todos esses assuntos são suficientemente relevantes para reunir interessados em desenvolvimento de sistemas e promover atividades colaborativas. Quando não houver conteúdo confidencial no código, reuniões no formato de Code Meeting (página 101) podem ser usadas para integrar equipes, exibindo casos reais de implementação sem a necessidade de investir tempo na 
preparação de exemplos de código.

Conforme dissemos, cada equipe e projeto necessita de práticas que se adeqüem ao seus contextos. Promover a integração e a troca de experiências entre equipes, mesmo que elas não compartilhem as mesmas filosofias de trabalho, é uma forma de aumentar a disseminação de conhecimento e expandir a gama de práticas que cada equipe retém em seu portifólio para usar no futuro.

\subsubsection{Combatendo a Resistência Superior - Alesp $\quad$ PR\&A Ikwa}

Gerentes, diretores e outros líderes acostumados com modelos tradicionais vêem atividades que colaboram para integrar socialmente a equipe de desenvolvimento de forma negativa [DeM01]. Apesar de diversos resultados comprovarem os benefícios da programação em pares [Nos98, WKCJ00, CW01], esta prática é comumente vista como desperdício de recursos e gera controvérsia. As práticas que sugerimos nas Seções 4.3.3, 4.2.6 e 4.2.7 também provocam essa sensação se analisadas em separado pois não produzem resultados facilmente mensuráveis, mas contribuem para a sinergia da equipe e do conjunto de práticas como um todo, portanto é importante destacar medidas que evidenciem esses benefícios.

Para esses líderes, as métricas que importam estão puramente relacionadas ao avanço na construção do software e, felizmente, para equipes ágeis, a entrega constante de software funcional é uma prioridade. Em métodos ágeis, as funcionalidades podem ser medidas de várias formas, como por exemplo, por pontos [Coh06], porém para tornar possível comparações que evidenciem a eficácia do conjunto de práticas usado pela equipe ágil, é interessante identificar uma forma de comparar os avanços usando as métricas de outras equipes. Para isso, sugerimos escolher métricas externas que destaquem avanços reais através da contagem de elementos finais do ciclo de produção do software, como por exemplo, funcionalidades entregues ou casos de uso concluídos ao invés de métricas com elementos intermediários do processo, como por exemplo, especificações elaboradas ou casos de uso identificados.

Essas medidas comparativas podem ser simplesmente aproximadas e devem ser de fácil obtenção para não tirar o foco do desenvolvimento. Por exemplo, podem ser calculadas em uma planilha a partir das métricas que a equipe já usa. Assim, a equipe pode evidenciar suas conquistas, balizar seu progresso e perceber se precisa rever suas práticas. 


\subsection{Práticas e Aspectos Motivacionais}

Como o desenvolvimento de software depende do envolvimento de pessoas em tarefas analíticas e criativas que estão sujeitas à influência de aspectos pessoais e emocionais, várias das práticas que propomos consideram também o fator humano presente nessas atividades. Por conta disto, apresentamos mais uma teoria, esta relacionada a questões que influem na motivação pessoal dos indivíduos. O psicólogo Abraham Maslow propôs a Teoria das Necessidades Humanas onde ele diz que a motivação e a produtividade são alcançadas à medida que uma hierarquia de necessidades é satisfeita [Mas54].

A Pirâmide de Maslow apresenta os cinco tipos de necessidades dos seres humanos e sugere que elas sejam atendidas da base para o topo (Figura 4.1).

- Necessidades Fisiológicas: Devem ser atendidas primeiro porque estão relacionadas às necessidades do organismo. Ar, água, alimento, descanso e exercícios são alguns exemplos.

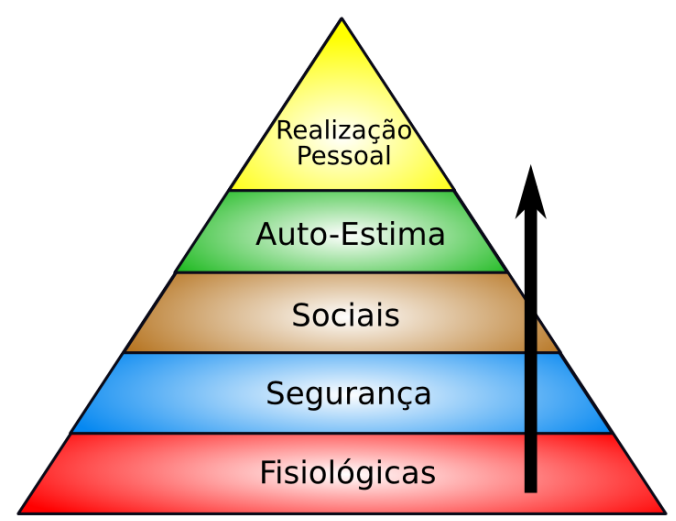

- Necessidades de Segurança: Impor- Figura 4.1: Pirâmide de Maslow com a hierarquia de tantes para criar a sensação de estabilidade necessidades que fortalecem a motivação. em relação a fatores que contribuem para o mínimo de conforto. Segurança física, segurança da família, segurança financeira e saúde produzem esse sentimento.

- Necessidades Sociais: Relações sociais sólidas estabelecem a sensação de pertencimento. Para isso são importantes a família e amigos que transmitam amor e preocupação.

- Necessidade de Auto-Estima: O respeito e a valorização por outros indivíduos atende necessidades de reconhecimento que criam o senso de propósito.

- Necessidade de Realização Pessoal: A liberdade para tomar decisões leva o indivíduo a confiar em sua capacidade. A sensação de superar desafios traz confiança em si próprio e conduz à satisfação pessoal. 
A satisfação das necessidades na ordem correta é importante porque quando isso não acontece elas perdem seu valor. Por exemplo, necessidades fisiológicas, como a alimentação, devem ser satisfeitas antes das necessidades de segurança, pois se ocorrer o contrário, o ser humano estará disposto a sacrificar sua segurança para conseguir comida. Da mesma forma, é importante oferecer condições de trabalho que atendam devidamente as necessidades dos indivíduos para que eles valorizem os benefícios que recebem e tenham motivação para trabalhar.

As práticas que apresentamos nesta seção provêem meios para atender as necessidades dos indivíduos e criar uma atmosfera de trabalho segura, agradável, com possibilidade para relações sociais e que valoriza e reconhece os esforços e contribuições de cada membro com o grupo. Essas práticas chamam a atenção para o lado humano do desenvolvimento de software, considerando as pessoas como indivíduos e não como recursos. Com o aumento do comprometimento e da motivação dos desenvolvedores teremos ganhos na produtividade e na qualidade no software.

\subsubsection{Responsabilidade Promove a Qualidade $\quad-\quad$ PR\&A Ikwa}

Os métodos ágeis dão enfoque para os indivíduos e valorizam as suas capacidades e habilidades. Os princípios da humanidade e da diversidade de XP destacam esses aspectos (página 52). Assim como o da valorização da equipe, de Lean (página 75) e a autonomia da equipe no Scrum (página 42) e no DSDM (página 35).

A valorização do trabalho de um indivíduo é uma forma de estimulá-lo para que ele continue buscando bons resultados. Quando um membro da equipe recebe uma responsabilidade, sua autoestima aumenta pois isto significa que o resto da equipe (ou ao menos o seu líder) acredita que ele é capaz de realizar a tarefa e confia que ela será bem executada. Duas maneiras de distribuir responsabilidades são:

Por Especialidade - Pedir para um especialista fazer o trabalho é sempre a solução mais segura. O risco de fracasso tende a zero e o tempo de desenvolvimento será menor. A experiência o ajudará a fornecer estimativas acuradas, com pouca incerteza associada. Entretanto, nem sempre a equipe dispõe de especialistas em todas as áreas, ou eles já estão alocados. Neste caso, uma membro com alguma experiência no assunto passa a ser uma boa escolha para substituir o especialista, com as devidas perdas de velocidade, eficácia, segurança e precisão. A estratégia de escolher pessoas com experiência tende a trazer resultados recompensadores para ambas as partes. Para o projeto, porque o resultado será provido por seu membro tecnicamente mais 
bem qualificado e, para o desenvolvedor, como um estímulo positivo por ter suas habilidades valorizadas ao receber tal responsabilidade.

Por Interesse - Permitir que uma pessoa trabalhe naquilo que tem interesse aumenta a sua dedicação e engajamento com a tarefa e com o projeto como um todo. Contudo, ter interesse não significa possuir aptidão para concluir o trabalho. Atribuir tarefas que sejam "desafios possíveis" é uma forma de evitar que o executor se frustre. Quando a atividade está muito além do conhecimento do interessado, ele pode ser envolvido com atuação secundária, auxiliando o responsável principal com seções de programação em pares, ou recebendo tarefas relacionadas porém mais simples. Envolver o indivíduo nas atividades que lhe interessam, mesmo sem estar capacitado, é uma forma de mostrar que seus interesses são reconhecidos e de aumentar sua experiência em um assunto no qual ele poderá se tornar um especialista no futuro. Isso significa investir na formação de um profissional que em breve reunirá experiência e interesse.

Sendo especialista ou interessado, o seu comprometimento é conseguido quando ele percebe que é o responsável pelo sucesso da execução. Para que isso aconteça, a equipe precisa confiar na sua capacidade e oferecer apoio, caso ele precise. Em nossos experimentos, o líder do projeto recebeu total confiança de seus superiores. Esta atitude o motivou para a condução do projeto. O líder transmitiu a confiança para os demais participantes distribuindo responsabilidades, oferecendo suporte quando preciso e dando o mérito pela conclusão da tarefa. Em troca, os membros da equipe respeitavam as decisões do líder e confiavam na sua condução do projeto. No caso da PR\&A, após a apresentação da terceira iteração aos clientes, um comentário feito por um dos programadores evidenciou esta prática: "No início, eu não acreditava que um sistema como esse pudesse ser feito dessa maneira, mas como você falou que daria, eu confiei. Agora estou convencido."

\subsubsection{Argumentos de Convencimento $\quad-$ Alesp PR\&A Ikwa}

A introdução de uma metodologia ágil em empresas com cultura de desenvolvimento tradicional em geral sofre resistência, principalmente de profissionais do nível gerencial, que não encontram os mecanismos que estão acostumados para planejamento e controle dos subordinados. Por isso, diversas empresas ainda evitam o uso de métodos ágeis. Porém, devido ao crescente número de relatos de casos de sucesso, mais empresas estão se propondo a usar essa abordagem em caráter experimental com uma pequena equipe ou em um projeto de menor importância. Entretanto, mesmo com bons resultados, mudar a cultura de desenvolvimento de uma empresa é um processo gradativo 
e de longo prazo que depende do interesse de desenvolvedores e gerentes e, em muitos casos, da aprovação da diretoria. Para convencer os tomadores de decisão a usarem XP, Freire descreve alguns padrões, como o Almoço VIP e o Histórias de Sucesso [Fre07]. Porém, para aumentar as chances de sucesso, é interessante que clientes, gerentes, diretores, programadores e até usuários queiram envolver-se com o processo de desenvolvimento, embora esses indivíduos possuem interesses distintos no desenvolvimento de um software. Por isso, é interessante apresentar as vantagens adequadas para cada perfil. Os principais argumentos de convencimento são os seguintes:

Diretores ganham o benefício da flexibilidade estratégica na produção de releases. Com ciclos de desenvolvimento curtos, versões podem ser liberadas freqüentemente para os usuários, mostrando o crescimento constante do software, ou em períodos mais longos, agrupando algumas iterações para produzir lançamentos maiores. O plano que agrupa iterações em releases pode ser construído e alterado com facilidade de acordo com decisões que envolvam, por exemplo, a estratégia da empresa, o plano de marketing, oscilações do mercado e posicionamento dos concorrentes.

Gerentes ganham com a redução do risco de planejamento e, conseqüentemente, com a diminuição do nível de estresse durante o projeto. Ganham também com a possibilidade de periodicamente fazer ajustes no plano junto com diretores e clientes para mantê-lo realista. Esta estratégia evita que mudanças de escopo sem mudança de planos causem surpresas no fim do projeto, ou que dificuldades na implementação sejam anunciadas somente próximo da data de entrega.

Programadores são beneficiados porque abordagens ágeis são centradas no desenvolvimento. A opinião deles passa a ter mais relevância para o projeto porque estão mais envolvidos com atividades de planejamento onde contribuem com pontos de vista e estimativas. O esquema de trabalho deixa de ser um processo onde cada um executa uma tarefa mecanicamente e a equipe mantém seu foco na implementação com um ambiente mais sociável e colaborativo.

Clientes aproveitam-se do contato antecipado e constante com o software antes de ser finalizado. Assim podem delineá-lo com um nível de detalhes que seria impossível sem um acompanhamento periódico. Baseado no conhecimento adquirido durante o projeto, as funcionalidades podem ser criadas, melhoradas ou adaptadas. As prioridades podem ser alteradas durante o desenvolvimento considerando o tempo e o custo com mais precisão à medida que o projeto evolui. 
Usuários beneficiam-se porque podem usar o software à medida que as releases são produzidas. Periodicamente, podem ter acesso a novas funcionalidades e suas opiniões são dadas a tempo de influenciar o desenvolvimento do restante do sistema.

\subsubsection{Refatorações Aumentam a Motivação - Alesp $\quad$ PR\&A Ikwa}

Durante a implementação, pequenas porções de código de baixa qualidade são inseridas quando os prazos estão acabando ou quando a equipe ainda não possui domínio completo das tecnologias que usa. À medida que os desenvolvedores identificam oportunidades para melhorias e as deixam para depois por falta de tempo, a preocupação e a ansiedade aumentam inconscientemente. Como resultado, o trabalho torna-se mais tedioso e estressante.

Para eliminar código de baixa qualidade, refatorar constantemente é a solução recomendada $\left[\mathrm{FBB}^{+} 99\right.$, Ker04, Bec03]. Esta prática atende às características de diversos métodos ágeis. Em XP, além de estar explicitada como uma de suas práticas, colabora com os princípios do benefício mútuo, melhoria, oportunidade e qualidade (página 52). Em Lean, ela auxilia a implementação do princípio Adicione Segurança (página 75). Nos métodos Crystal, assim como em FDD, a Rearquitetura Incremental sugere melhorias contínuas no design do sistema durante o projeto (página 66), assim como a prática da evolução da arquitetura de EVO (página 35) e o princípio do desenvolvimento iterativo e incremental de DSDM (página 35).

Realizar refatorações é uma prática que incentiva os desenvolvedores pois eles passam a maior parte do tempo envolvidos com o código, que é o principal produto do seu trabalho. Estimular a melhoria da qualidade do código significa oferecer melhores condições de trabalho, pois com código de boa qualidade, o esforço para implementar as próximas funcionalidades e a chance de erros são menores.

Refatorações simples podem ser facilmente intercaladas durante o desenvolvimento de novas funcionalidades. Porém, para refatorações maiores (geralmente envolvendo mudanças na modelagem ou na arquitetura), é necessário reservar mais tempo para fazê-las [Lip04]. Uma possível estratégia é ter cartões de refatoração escritos pela equipe de desenvolvimento para serem considerados no planejamento da iteração. Porém, misturar cartões de refatoração com cartões de funcionalidade divide a força de desenvolvimento e requer um esforço maior para conciliar tarefas relacionadas ou dependentes. A conseqüência dessa mistura de atividades é a produção de funcionalidades usando conceitos que ainda não estão completamente definidos ou implementados. Por outro lado, retar- 
dar as refatorações implica mais trabalho de integração, pois as novas funcionalidades precisarão automaticamente ser refatoradas.

As equipes com que trabalhamos solicitaram regularmente tempo para refatorar. Para atender a esses pedidos, reservamos periodicamente alguns dias para dedicar à refatorações não-triviais. A entrega de funcionalidades e o planejamento das iterações aconteceu normalmente, porém quando havia um volume grande de refatorações críticas identificado, alguns dias eram negociados com os clientes antes do início da próxima iteração. Neste período, os desenvolvedores focavam seus esforços para melhorar a qualidade do código e para prepará-lo para as funcionalidades das próximas iterações.

Reservando um período específico para refatorações, as equipes sentiam-se mais valorizadas porque percebiam que seus pedidos haviam sido considerados. Sem a mistura de cartões de funcionalidades com refatorações, a equipe pode trabalhar com um só objetivo, evitando desperdício de tempo e esforço. Após a fase de refatorações, as equipes mostraram-se mais confiantes e satisfeitas com seus trabalhos. Os desenvolvedores ficaram mais motivados e produtivos por trabalharem em um código que tinha atingido o que acreditavam ser "a melhor solução para o problema", ao menos até aquele momento do desenvolvimento.

Em debates com os desenvolvedores, ficou claro que a possibilidade de fazer refatorações periódicas é vista de forma positiva pela equipe. Esta prática foi classificada como um elemento que favorece o interesse pelo projeto e também foi incluída como uma condição essencial para o ambiente de trabalho ser confortável e produtivo, assim como são cadeiras adequadas ou memória extra para os computadores.

\subsubsection{Hierarquia Fraca $\quad-\quad$ PR\&A Ikwa}

As hierarquias na indústria se apóiam no conceito de chefe e subordinados, que estabelecem uma relação de poder que tende a inibir os indivíduos das posições inferiores. Observando as camadas superiores da hierarquia das empresas, percebemos a presença de conselheiros auxiliando na tomada de decisões complexas e importantes. Nestes casos, a hierarquia prevalece, porém as decisões são tomadas em grupo.

Métodos ágeis valorizam os desenvolvedores aumentando o seu envolvimento nas decisões e oferecendo liberdade para contribuírem com opiniões durante o processo de desenvolvimento. Isto é evidenciado pela propriedade da Segurança Pessoal, de Crystal (página 64), pela iteração da equipe de desenvolvimento com o Scrum Master (página 40), pela praticamente ausência hierárquica em XP 
(página 49) e pelo princípio da Valorização da Equipe, de Lean (página 75).

Considerando as práticas ágeis e subvertendo o conceito do conselho para as camadas inferiores da hierarquia, podemos pensar em uma forma amenizada de uso do poder do chefe na condução de projetos. O papel do chefe onipotente é substituído pelo do líder que oferece liberdade para a equipe participar das decisões de planejamento e implementação. Apesar da experiência do chefe, o resto da equipe possui opiniões que devem ser consideradas. O líder usa sua experiência para fazer o melhor julgamento dessas opiniões e para ajudar a equipe a tomar suas decisões.

A criação de uma hierarquia fraca se baseia na criação de um ambiente colaborativo, ao invés de coercivo, e na presença de um líder que oferece apoio à equipe fazendo uso de sua posição superior apenas quando é necessário: em momentos de indecisão, situações de impasse ou para corrigir decisões erradas que a equipe tomaria. Os participantes da equipe atuam com mais liberdade para contribuir com idéias, ao invés de atuarem apenas como mão-de-obra para executar as tarefas idealizadas pelo chefe.

Percebemos aumento do interesse e melhora nos resultados quando houve mais abertura para contribuições e o líder usou sua experiência e poder hierárquico para conduzir os passos da equipe. Neste caso, o líder abriu mão de exclusivamente dar ordens em troca de uma equipe mais motivada. Os membros novatos motivaram-se por verem-se mais próximos dos experientes. Os veteranos perceberam a sua importância pois suas experiências colaboraram fortemente para a condução do projeto e o líder deixou de tomar decisões e passou a endossá-las.

Durante o desenvolvimento, todos são vistos no mesmo nível hierárquico e são estimulados a contribuir com opiniões e sugestões. Quando escolhas precisam ser feitas e, mesmo depois de pesquisas e discussões, a equipe ainda tem opiniões divergentes ou não possui convicção da melhor opção, o líder assume seu papel de comando. Apesar da equipe ter liberdade, ela reconhece a autoridade e a experiência do líder quando dá uma recomendação.

\subsubsection{Desenvolvimento Mercenário - PR\&A Ikwa}

Recompensas são uma forma de motivar a equipe para atingir um objetivo. Porém, evidências empíricas indicam que incentivos financeiros não implicam aumento de desempenho [JMGS98,Koh93, JJ86]. Alfie Kohn diz que recompensas pelo cumprimento de tarefas trazem apenas satisfação temporária e não promovem o comprometimento real com objetivos de longo prazo [Koh93]. Uma posterior ausência de recompensas, provoca desmotivação e a sensação de que algo a mais deveria ser ganho 
pela execução das tarefas. Em sua pesquisa sobre a influência de planos de incentivo nos resultados, Kohn afirma que os melhores resultados são alcançados sem recompensas [Koh93]:

“...pessoas que esperam receber recompensas para completar uma tarefa ou para fazêla com sucesso simplesmente não as realizam tão bem quanto aquelas pessoas que não esperam recompensas".

Alfie Kohn, 1993

Jenkins conduziu estudos em laboratório e em campo que mediram o impacto de incentivos financeiros na produtividade dos indivíduos [JJ86]. Em 57\% dos casos, os incentivos trouxeram resultados positivos em medidas quantitativas, mas apenas $17,8 \%$ dos casos apresentaram aumentos qualitativos, sendo que nenhum deles foi motivado por recompensas.

Em nossos estudos, percebemos que o desenvolvimento de sistemas baseado em incentivos com metas agressivas induzem os desenvolvedores a aumentar a quantidade de funcionalidades produzidas inicialmente, porém implicou o aumento do número de erros e perda de qualidade do código, tornando mais difícil a manutenção e reutilização do código. O modelo de metas agressivas e recompensas tende a não se sustentar no longo prazo, pois em pouco tempo o ritmo de desenvolvimento diminui e os incentivos precisarão ser aumentados, criando uma bola de neve que encarece cada vez mais o desenvolvimento, degenera a qualidade do código e cria um clima de tensão entre clientes e desenvolvedores. Os primeiros, ao oferecerem incentivos, sentem-se cada vez mais à vontade para fazer cobranças e exercer pressão sobre os desenvolvedores, que para compensar a pressão, passam a se sentir no direito de receber mais para fazer o trabalho.

\subsubsection{Desafios com Prêmios $\quad-\quad$ PR\&A}

$\mathrm{XP}$ sugere que os programadores tenham liberdade para escolher as tarefas com as quais gostariam de trabalhar. Implementações de grande dificuldade ou erros que a equipe reconhecidamente não consegue resolver tornam-se tarefas menos atrativas pois o tempo investido nelas acaba trazendo resultados menos expressivos que em implementações normais. Isto faz com que algumas dessas tarefas complicadas sejam menos motivantes para os programadores e elas sejam deixadas por último. Com o tempo, mais cedo ou mais tarde, a equipe elege alguém para trabalhar nelas ou, por falta de opção, essas tarefas são escolhidas. 
Para estimular a escolha espontânea das tarefas complicadas, nossa equipe usou uma estratégia que ajuda a evitar que elas se acumulem no final da iteração: cartões ou post-its com tarefas complicadas foram colados em uma área reservada do quadro branco do ambiente de trabalho. Elas passavam a ser encaradas como desafios e ficavam à disposição de quem quisesse tentar resolvê-las. O programador que eliminasse uma dessas tarefas seria simbolicamente recompensado pela equipe com guloseimas, em sinal de agradecimento por uma contribuição para a evolução do trabalho de toda a equipe.

Apesar desta prática aparentemente conflitar com o Desenvolvimento Mercenário (Subseção 4.2.5), a natureza da premiação é diferente. Primeiro, o desafio é opcional, qualquer um pode escolher fazêlo. Logo, o estresse do projeto não aumenta por causa dele. Segundo, ao invés de premiações vindas de fora da equipe, que causariam competições internas por interesses individuais, a equipe de desenvolvimento se dispõe a recompensar um de seus membros mostrando que seu trabalho é importante para o grupo. Isso aumenta a auto-estima do recompensado e o seu comprometimento com o resto do time. Portanto, a recompensa não tem um valor financeiro significativo. O valor é simbólico.

\subsubsection{Quebra de Rotina - Ikwa}

Apesar da importância de um fluxo de trabalho definido e claro, a sua constante repetição tende a tornar o trabalho entediante e a diminuir a motivação e o rendimento da equipe [DeM01]. Percebendo isso, Law e Charron relataram o aumento da motivação através de atividades sociais periódicas $[\mathrm{LC} 05]$.

Em nossos projetos, introduzimos mudanças na maneira de realizar algumas atividades do dia-adia para torná-las mais agradáveis. Com isso conseguimos quebrar a rotina sem quebrar o fluxo de trabalho, transformando tarefas do trabalho em atividades sociais. As principais ações que promovemos foram:

- Retrospectivas ao ar livre. Mudamos o local onde as retrospectivas ocorriam para o terraço do prédio $^{2}$. Neste ambiente, os participantes mostraram-se mais dispostos a identificar os problemas do processo de desenvolvimento e em contribuir para melhorá-lo.

- Semana sim, semana não, as reuniões de aprovação de layout foram realizadas em um café

\footnotetext{
${ }^{2}$ A Ikwa ocupa o andar na cobertura de um prédio comercial. Suas dependências incluem um terraço ao ar livre de aproximadamente $18 \mathrm{~m}^{2}$, subaproveitado inicialmente, mas que passou a ser usado para atividades de Quebra de Rotina
} 
próximo à empresa, onde a equipe costumava ir regularmente no intervalo do trabalho. Inicialmente, a aprovação servia para validar o trabalho dos designers, exigindo que posteriormente alguns comportamentos e detalhes da interface fossem explicados para os programadores. Unimos a necessidade de fazer duas reuniões ao que antes era uma pausa no trabalho. A mudança aumentou o interesse da equipe na aprovação do layout e eliminou uma etapa do processo, pois os programadores passaram a acompanhar as discussões sobre a interface e compreendiam seus detalhes sem que novas conversas ou reuniões sobre este assunto precisassem ser realizadas.

- Esporadicamente, a equipe levava seus computadores portáteis e demais ferramentas de trabalho ao terraço do prédio para trabalhar ao ar livre. Funcionários de outras áreas, mesmo sem saber programar, declararam ter vontade de participar do grupo para poder usufruir dessa atividade. Isso fez com que os membros da equipe se sentissem privilegiados por fazer parte de um time com mais liberdade.

Esses benefícios foram concedidos deixando claro como contrapartida que a equipe tivesse responsabilidade e comprometimento.

\subsubsection{Motivação pelo Trabalho $\quad-$ Alesp Colméia PR\&A Ikwa}

Metodologias pesadas investem muitos esforços na produção de documentação, na utilização de ferramentas e em tarefas burocráticas que consomem uma parcela considerável do tempo dos desenvolvedores. Essas atividades, tiram o foco do objetivo final, que é produzir o software. Além disso, tornam o trabalho de desenvolvimento entediante para os bons programadores, pois eles não estão fazendo o que gostam: programar.

Tom DeMarco diz que os programadores precisam de "tempo de qualidade" para produzir software. Este tempo é um período no qual o programador pode concentrar-se na solução do problema sem ser interrompido ou incomodado com outras atividades [DL99].

Metodologias ágeis influenciam diretamente no modo de trabalho dos programadores porque a baixa quantidade de documentação extra e de ferramentas de controle fazem com que a porcentagem de tempo dedicada à programação seja maior. Os desenvolvedores passam mais tempo fazendo o que gostam e, fazer algo por gosto é mais satisfatório e produtivo do que por obrigação [Koh93]. Portanto, a tarefa principal, que é a implementação, será feita com mais qualidade.

Em nossos casos de estudo, chegamos a essas conclusões a partir de entrevistas individuais com os 
desenvolvedores. Em todos os projetos, a maioria declarou ter gostado de participar e ter aprendido muito. Em suas opiniões, os aprendizados que mais se destacaram foram relacionados ao uso de arcabouços, ao trabalho em equipe, à produção de testes automatizados e às práticas de refatoração.

\subsection{Práticas de Desempenho}

As práticas de desempenho têm como seu principal objetivo identificar formas de aproveitar os esforços da equipe e amplificar seus resultados qualitativa ou quantitativamente.

\subsubsection{Solução Mínima - Ikwa}

As equipes de negócio sempre querem oferecer uma grande variedade de funcionalidades aos usuários. Contudo, a maioria delas é pouquíssimo usada [Joh02]. Isso é um desperdício que acontece quando o cliente pensa que entende as necessidades e interesses do usuário, ou porque, na dúvida, espera incluir todas as funcionalidades possíveis e depois descobrir aquelas que o usuário irá, de fato, usar. Este é um problema de definição de escopo e de priorização.

Com base no método de prototipação, no conceito de produzir soluções simples de XP [Bec99], nas estratégias de Esqueleto que Anda e Rearquitetura Incremental, de Crystal (página 66) e dos princípios Elimine Desperdícios e Adie Comprometimentos, do desenvolvimento Lean [PP03], percebemos que o tempo e os esforços para a obtenção de uma versão comercializável de novos produtos de software pode ser reduzido quando a equipe de negócios/cliente concorda em ter inicialmente uma solução com o mínimo de recursos básicos que a torne funcional (Solução Mínima). Assim, a equipe de desenvolvimento consegue produzi-la rapidamente e coletar facilmente opiniões de usuários, sem envolvê-los em discussões abstratas.

As sugestões dos usuários junto com suas próprias experiências de utilização darão à equipe de negócios condições de aumentar a sua compreensão sobre as necessidades. A experiência proporcionada por um sistema simplificado em operação ajudará no amadurecimento das funcionalidades e permitirá que a equipe distinga as funcionalidades necessárias das supérfluas e, portanto, facilitará a eleição de prioridades.

O tempo e os esforços totais para a concepção da solução final serão menores pois evitarão que sugestões e opiniões baseadas em suposições durem muito tempo. O cliente não supõe que conhece as vontades dos usuários sobre funcionalidades que ainda não existem, evitando criar uma falsa sensação de estabilidade de requisitos que desmotiva os desenvolvedores quando eles têm seu 
trabalho descartado várias vezes devido a solicitações erradas do cliente.

\subsubsection{Layout Exposto - Ikwa}

Clientes ficam ansiosos e curiosos para saber como o software ficará quando pronto. Para reduzir esta ansiedade e garantir que desenvolvedores e idealizadores estejam falando do mesmo produto, protótipos podem ser feitos no início do desenvolvimento. Os protótipos ajudarão a definir a interface gráfica e apoiar os programadores, porém, como metodologias ágeis seguem modelos iterativos, é razoável que o layout da interface também siga esta abordagem, permitindo que melhorias e adaptações sejam incorporadas durante o processo. Essa estratégia permite retardar decisões para considerar o conhecimento que as pessoas adquirem durante o projeto [PP03].

Para chegar a uma solução que atenda às necessidades de negócio, clientes podem trabalhar junto com designers fazendo sugestões e determinando as diretrizes que gostariam de ver no layout da interface. XP defende essas iterações através dos princípios da diversidade e da melhoria [BA04]. Porém, a curiosidade de pessoas de fora da equipe ou a ansiedade do cliente de aprimorar e incluir novas funcionalidades ocupa o tempo dos desenvolvedores e designers com pedidos de demonstração da interface ou do protótipo.

Para facilitar o acompanhamento por pessoas que não participavam do desenvolvimento, imprimimos a parte mais relevante da interface e a colamos nas paredes do ambiente de desenvolvimento, constituindo mais um radiador de informações. Clientes, visitantes, usuários e desenvolvedores podiam visualizar e discutir sobre a interface sem interromper outros membros da equipe. Antes da utilização desta prática, os desenvolvedores precisavam, em média, parar seu trabalho por 30 minutos para cada pedido de visualização da interface. Com essa prática, muitas interrupções foram evitadas e a interface exposta ainda ajudou nas discussões sobre o layout.

A parede onde a interface foi afixada se tornou um local para a equipe fazer reuniões em pé e discussões sobre a implementação. Neste local, é possível visualizar vários pontos da interface ao mesmo tempo e encontrar com mais facilidade pequenas discrepâncias que podiam ser ajustadas à caneta, para mais tarde, serem incorporadas ao software de uma só vez.

\subsubsection{Posicionamento Otimizado - Ikwa}

O ambiente de desenvolvimento é um fator importante em métodos ágeis para favorecer a comunicação e o espírito colaborativo da equipe [BA04, Coc06]. Poucas paredes, proximidade entre 
as pessoas, facilidade de comunicação e acesso fácil às informações são algumas das características desejadas. Para Cockburn, ambientes com essas características são essenciais, uma vez que sua metodologia é fortemente baseada na comunicação osmótica [Coc04]. Contudo, mesmo em um ambiente propício à comunicação, percebemos variações que a favorecem ainda mais, criando mais oportunidades para contribuições.

A partir da programação em pares e da programação lado a lado (página 70), percebemos como distribuir os desenvolvedores no ambiente para intensificar o trabalho colaborativo. Notamos aumento da comunicação e da qualidade do código quando pessoas que trabalham em atividades semelhantes sentam-se lado a lado e pessoas com atividades dependentes sentam-se frente a frente.

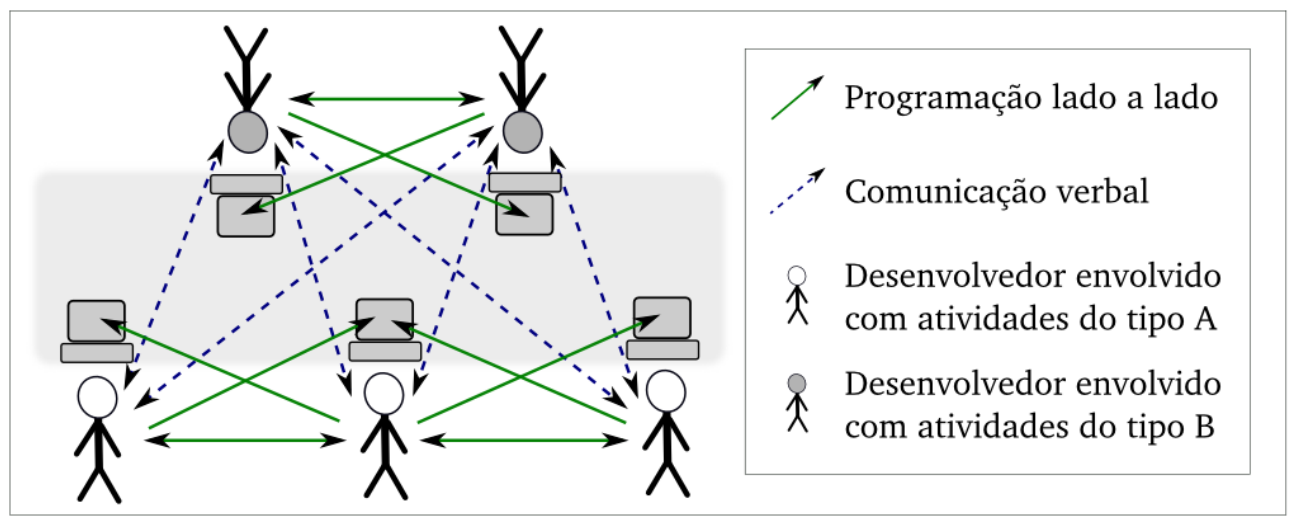

Figura 4.2: Disposição física dos desenvolvedores conforme suas atividades.

Quando desenvolvedores que trabalham em tarefas parecidas estão lado a lado, eles podem facilmente fazer consultas entre si e dar sugestões apenas olhando no monitor ao lado e, se preciso, realizar programação em pares sob demanda (página 99). Para desenvolvedores que realizam tarefas relacionadas ou dependentes entre si, como por exemplo, interface e camada de negócios, ou camada de negócios e banco de dados, a comunicação acontece na forma de pequenas perguntas e respostas. Esse tipo de colaboração exige a proximidade física para a comunicação rápida, o que torna o posicionamento frontal ou diagonal mais adequado.

Na Figura 4.2 podemos observar a disposição física dos desenvolvedores que otimiza a comunicação. As setas contínuas representam trocas de informação realizadas durante a programação lado a lado, enquanto que as setas tracejadas indicam a comunicação que ocorre entre desenvolvedores 
que executam tarefas relacionadas ou dependentes. Para os primeiros, é importante o posicionamento lateral para opinar e colaborar com o trabalho alheio. Para tarefas dependentes, este tipo de comunicação não é necessária. A proximidade e a facilidade para tirar dúvidas passa a ser mais importante.

\subsubsection{Controlando a Instabilidade $\quad-\quad$ Ikwa}

Apesar de metodologias ágeis oferecerem o benefício da flexibilidade para mudanças durante o desenvolvimento, existe um limite de instabilidade para garantir produtividade da equipe. Scrum recomenda sprints de duas a quatro semanas [Sch04]. XP sugere iterações curtas e preferencialmente de tamanho fixo [BA04], Crystal Clear recomenda iterações de no máximo três meses [Coc04] e Crystal Orange Web iterações de duas semanas [Coc06]. Quando não existe um período para a equipe trabalhar sem que as funcionalidades mudem, os desenvolvedores encontram requisitos que aparecem e somem em curtos períodos de tempo, dando sinais de instabilidade excessiva. Batizamoos de Requisitos Faísca, pois desaparecem rapidamente e evidenciam atrito entre idéias que ainda não se acomodaram.

Requisitos faísca podem ser causados por diversos motivos: falta de comunicação entre participantes da equipe de negócios; muitos clientes com poder de decisão interagindo com a equipe de desenvolvimento; ou pequenas requisições feitas sem considerar os seus impactos em todo o software.

A mutabilidade excessiva dos requisitos prejudica o trabalho, mesmo usando uma metodologia ágil. Por isso, uma das razões pelas quais iterações são definidas é proteger a equipe da instabilidade do projeto. Contudo, algumas equipes se propõem a ser "ágeis ao extremo" quando tentam atender a todas as solicitações de imediato. Porém, quando "ágeis ao extremo" lidam com requisitos faísca, a tendência é a perda de produtividade e a desmotivação, pois os requisitos mudam mais rápido do que a equipe consegue desenvolver e o software entregue nunca atenderá às expectativas do cliente. Mesmo tendo cumprido os prazos e objetivos de implementação, o esforço para o desenvolvimento será pouco valorizado pelo cliente e a equipe se sentirá desmotivada por perceber que seu trabalho não teve reconhecimento.

Depois de refazer diversas funcionalidades várias vezes, a equipe de desenvolvimento sabe que seu trabalho será sacrificado porque as funcionalidades não são claras. Como defesa natural, os programadores perdem a confiança na equipe de negócios e passam a questionar se devem realizar as implementações prontamente ou não, pois sabem que, se esperarem um pouco, podem evitar a 
implementação de uma versão que será imediatamente descartada. Por outro lado, correm o risco de causar atraso se a funcionalidade não mudar. Essa incerteza causa insegurança e desconforto em relação ao projeto.

Em nossas experiências, percebemos uma sensível perda de produtividade quando os requisitos mudavam com muita velocidade. O software desenvolvido na linguagem Ruby, usando o arcabouço Ruby on Rails gerou grandes expectativas nos clientes devido à boa produtividade no início do projeto. Quando funcionalidades passaram a mudar de comportamento diariamente, a equipe gastava seu tempo refazendo tarefas dadas como prontas, tentando ser "ágil ao extremo" e deixando de produzir novas funcionalidades. Os resultados foram: 1) grande ansiedade nos clientes que esperavam que o ritmo de inovações fosse mantido e 2) desmotivação na equipe de desenvolvimento porque percebia que seu trabalho nunca era satisfatório e várias vezes era descartado.

Para reduzir as divergências e manter a flexibilidade, a equipe deixou de tentar ser "ágil ao extremo" definindo um conjunto de funcionalidades que faria durante a iteração, mas permitiu que as tarefas fossem trocadas. Cada nova requisição era avaliada e estimada pelos desenvolvedores, depois os clientes decidiam se queriam que a equipe investisse seu tempo naquela tarefa. Dessa forma, mesmo não fixando completamente o escopo da iteração, as requisições que a equipe de fato precisou fazer diminuíram porque ao considerar o tempo de desenvolvimento, os clientes reavaliavam suas necessidades para fazer solicitações mais estáveis. No final da iteração, a equipe tinha uma listagem das tarefas concluídas, inclusive com os requisitos faísca, mas que mostrava claramente a sua produtividade.

\subsubsection{Personagens $\quad-$ Ikwa}

Ao desenvolver software com agilidade, a equipe precisa entregar elementos com valor de negócio para o cliente. Isso acontece quando os interesses dos usuários são identificados e estes enxergam benefícios em usar o software. Porém, diferenças culturais, sociais, econômicas, de idade e de interesse contribuem para que existam muitos perfis de usuários. De acordo com Kent Beck, o designer de iterações é o responsável por identificar formas de tornar a navegação agradável e auxiliar o cliente na escrita dos cartões [BA04]. Cockburn recomenda conhecer os usuários do sistema através da Descoberta de Interações de Usuário [Coc04] e Mike Cohn sugere escrever cartões que explicitem o tipo de usuário e o valor de negócio que a funcionalidade traz, seguindo a seguinte estrutura:

Como um < usuário/papel>, eu gostaria de < funcionalidade $>$ para <benefício/valor de negócio $>$ 
Neste modelo, o cliente pode destacar os benefícios associados a cada funcionalidade e identificar os usuários que se interessam por elas [Coh06]. Com a mescla do padrão de Cohn com o uso de Personas proposto por Cooper [Coo04] sugerimos um uso de personagens para fortalecer alguns princípios e práticas de XP, conforme descrito em [SBG07]:

- o valor da comunicação é intensificado através da criação de uma metáfora para a equipe;

- o uso de um rosto humano estimula a percepção cognitiva e aumenta a humanidade no desenvolvimento;

- a diversidade da equipe faz com que o designer de interfaces trabalhe mais próximo dos outros membros;

- a partir dos perfis de usuário, diferentes cenários de uso e interação são considerados no desenvolvimento e nos testes;

- melhora-se a qualidade do sistema aumentando a sua usabilidade.

As personagens são pessoas fictícias que representam os maiores grupos de usuários do sistema. Para compor o perfil de cada personagem, várias fontes colaboram com informações, tais como entrevistas, questionários, grupos de foco, testes de usabilidade, ou pesquisas de mercado [PA06]. As informações de cada uma são armazenados em fichas que ficam disponíveis para a equipe se referenciar durante o todo o desenvolvimento. Cada ficha exibe os seguintes dados:

- nome e foto;

- dados pessoais (idade, formação, estado civil);

- interesses pessoais no sistema;

- objetivos e tarefas realizadas no sistema;

- personalidade e características comportamentais.

Para adotar esta prática é importante saber que as personagens não irão representar todas as possibilidades de interação com o sistema. O foco deve ser mantido inicialmente nos maiores grupos, 
depois novas personagens poderão surgir conforme o conhecimento sobre o sistema aumenta. A identificação das personagens também não deve despender esforço demais. O processo de criação pode ser feito iterativa e incrementalmente durante o projeto através de testes de usabilidade e entrevistas com usuários reais.

\subsubsection{Limite para Refatoração - Alesp $\quad$ Ikwa}

Refatorações devem ser feitas a todo momento [Bec99] como um mecanismo para mitigar o risco e minimizar a complexidade do código [PP06]. Durante o andamento do projeto, a equipe identifica naturalmente pequenos problemas e possíveis refatorações em vários níveis, como na arquitetura, na modelagem, em algoritmos ou em testes. Fowler sugere que as refatorações sejam realizadas constantemente $\left[\mathrm{FBB}^{+} 99\right]$. Porém, muitas vezes elas são deixadas para mais tarde, por limitações de tempo, por influenciarem em partes do software que estão fora do escopo ou por sua complexidade impor dependências na alteração do código. Lippert fala que a aparição de grandes refatorações é natural e sugere resolvê-las traçando um plano para identificar os passos da refatoração [Lip04]. Na prática, refatorações muitas vezes são deixadas para depois. Neste caso, é relevante manter um acompanhamento dessas pendências para que a equipe permaneça ciente da sua existência e possa avaliar e planejar o melhor momento para realizá-las.

O Limite para Refatoração é um radiador de informações (página 67) que reforça os valores de XP. A comunicação e o feedback são melhorados porque o ambiente de trabalho é aprimorado com informações que mantêm os clientes informados sobre as necessidades de melhoria no código e ajuda os desenvolvedores a acompanhar essas refatorações e a se lembrar de fazê-las mais tarde. Isto dá coragem para a equipe aceitar a responsabilidade de manter a qualidade e cria oportunidades para melhoria no software, garantindo que o código permaneça fácil de ler e manter.

O Limite para Refatoração é representado por um gráfico que mostra as refatorações ainda precisam ser feitas. Neste gráfico, os desenvolvedores definem dois patamares, representando o seu Limite de Conforto (CFT) e o seu Limite Crítico (CRT). O primeiro é o número de refatorações pendentes que a equipe julga não afetar a qualidade do software, enquanto que o segundo indica um limite que nunca deve ser superado por mais do que um dia pois muitas refatorações pendentes irão conduzir a qualidade do código para um nível crítico.

Para acompanhar o número de refatorações, usamos o Eclipse adicionando marcas "TODO" no código. A equipe definiu ainda diferentes categorias de "TODOs" para agrupar tipos relacionados 
de refatorações, como de interface, na arquitetura, nos testes, entre outras.

Refatorações podem ser identificadas ou realizadas a qualquer momento, por isso o tracker do projeto deve atualizar o gráfico diariamente com a quantidade de refatorações pendentes (Figura 4.3) e a equipe tem sempre o objetivo de reduzir este número. Quando o número de refatorações está entre o CFT e o CRT a equipe deve prestar atenção para que ele não atinja o CRT. Se o CRT for superado, toda a equipe deve trabalhar para eliminar as refatorações pendentes até que elas cheguem pelo menos ao CFT.
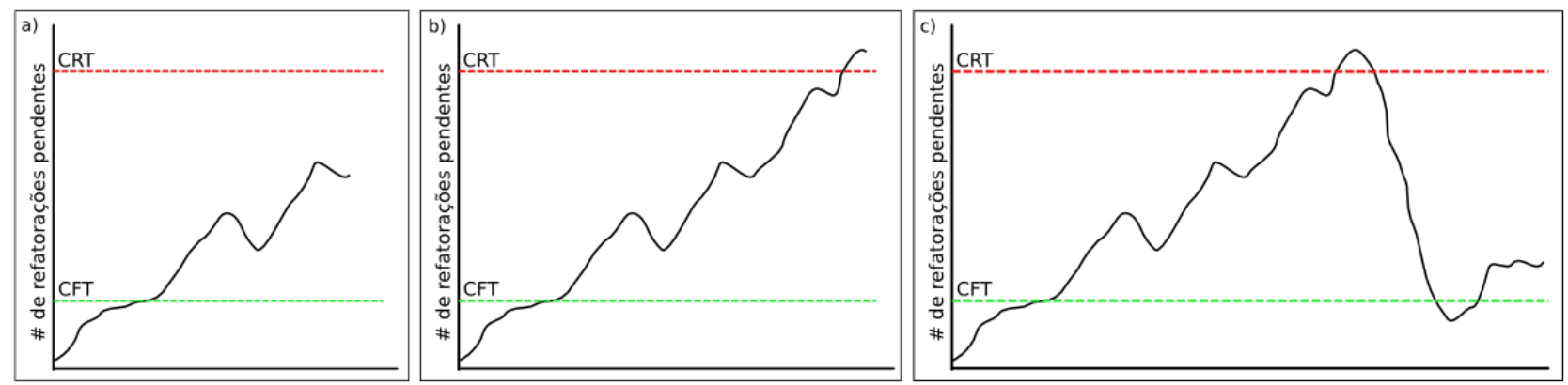

Figura 4.3: Exemplo de evolução da quantidade de refatorações pendentes com relação ao CFT e ao CRT.

Na Figura 4.3 (a), vemos um exemplo do crescimento do número de refatorações identificadas pela equipe. Na Figura 4.3 (b), o número de refatorações supera o CRT e, na Figura 4.3 (c), vemos a redução na quantidade de refatorações por fazer até atingir um patamar abaixo de CFT. Quando o CFT é alcançado, o número de refatorações chega a um nível abaixo do que o projeto esteve em seu passado recente e a qualidade do código estará em um patamar que a equipe considera seguro ${ }^{3}$.

Quando esta prática foi adotada em nossos casos de estudo, a equipe ficou consciente de que criar uma lista de refatorações pode gerar uma lista de trabalho que nunca será feito. Para evitar esse problema, foram definidos valores pequenos para CFT e CRT. Percebemos também que em projetos onde é difícil mostrar ao cliente o valor de refatorações ou mesmo reservar tempo dentro das iterações para introduzir melhorias no código, o mapeamento das refatorações pendentes facilita a transformação delas em tarefas que podem ser estimadas e incluídas na iteração.

\footnotetext{
${ }^{3}$ Os fatores que relacionam refatorações com a segurança da equipe podem ser encontrados na prática Refatorações Aumentam a Motivação, Subseção 4.2.3.
} 


\section{$\begin{array}{llllll}\text { 4.3.7 Integrando a Equipe } & - & \text { Alesp } & \text { Colméia } & \text { PR\&A } & \text { Ikwa }\end{array}$}

Na ALESP, o período de contato da fase de treinamento (Subseção 3.2.4) foi importante para estabelecer um bom relacionamento entre duas equipes que não se conheciam, os consultores do IME-USP e os funcionários da ALESP. As equipes tiveram a oportunidade de trabalhar juntas em atividades didáticas, sem a pressão e atritos que existiriam em projetos reais. Esta convivência eliminou uma potencial resistência da equipe local com a presença de outro time na liderança do projeto em seu ambiente de trabalho.

A comunicação foi imprescindível e determinante para a obtenção de bons resultados. Durante o período de integração, a equipe da ALESP percebeu que o pessoal do IME-USP estava trazendo benefícios através de conhecimento e experiência que seriam úteis em seu projeto. O bom relacionamento pessoal acelerou o processo de transmissão de conhecimento técnico para os iniciantes de desenvolvimento ágil e também permitiu que a equipe do IME compreendesse mais rapidamente as regras de negócio, as necessidades da equipe e as dificuldades do projeto.

Na PR\&A e na Ikwa, integramos novos membros à equipe com programação em pares. Programadores que não conheciam o código, ou recém-contratados, que também não conheciam os outros desenvolvedores, passavam uma semana trabalhando em par com um programador da equipe. Este período serviu para que os novatos absorvessem os hábitos da equipe e aprendessem a trabalhar com as ferramentas usadas no projeto: a plataforma de desenvovimento (Eclipse), os arcabouços e as ferramentas de integração de código. Durante o período de integração, os iniciantes também adquiriram uma visão geral da organização do código e foram integrados socialmente.

Nas práticas Posicionamento Otimizado (Subseção 4.3.3), Quebra de Rotina (Subseção 4.2.7) e Desafios com Prêmios (Subseção 4.2.6) a equipe passa por atividades que promovem a integração e contribuem para criar um ambiente de desenvolvimento colaborativo. Depois que essas práticas foram implementadas percebemos uma redução no número de erros no código e aumento na comunicação durante a implementação. Concluímos que esses resultados são decorrentes do estreitamento das relações interpessoais, uma condição que tornou as pessoas mais dispostas a pedir ajuda quando esbarravam em problemas, sem medo ou vergonha de expor suas dificuldades, pois sabiam que os demais tinham boa vontade em oferecer ajuda. A integração também facilitou atividades que envolviam mais de um desenvolvedor, como a programação em pares sob demanda (página 99), discussões sobre implementação e pedidos de revisão de código. E em retrospectivas, as equipes mostraram-se mais propensas a admitir seus erros e a buscar melhorias no processo de desenvolvimento. 


\section{Capítulo 5}

\section{Considerações Finais}

Em meio às percepções obtidas a partir dos quatro projetos que analisamos e, baseados em diversos relatos presentes na literatura, reunimos evidências que reforçam que a complexidade inerente ao desenvolvimento de software ultrapassa o escopo dos aspectos técnicos e invade o mundo do relacionamento entre indivíduos, envolvendo fatores motivacionais e psicológicos com pesos muito maiores do que os modelos de certificação e os métodos tradicionais supõem.

Enquanto a execução de um software é uma tarefa precisa, a sua produção não é. A execução é feita por uma máquina, enquanto que o desenvolvimento, por pessoas. Essa diferença é ignorada por métodos prescritivos que baseiam seus esforços no processo como se ele fosse o responsável pela produção do software. Processos não irão produzir software, mas os indivíduos irão. Portanto o modelo de desenvolvimento deve ser baseado nos indivíduos, o que significa considerar as características humanas durante o processo. Pessoas não mantêm um ritmo constante de trabalho, não reproduzem tarefas de alta precisão e estão sujeitas a oscilações em seus relacionamentos. Por outro lado, possuem habilidades que máquinas e processos dificilmente conseguem reproduzir. Pessoas estão expostas a muito mais informações do que é possível documentar ou fornecer a sistemas. Por isso, elas conseguem avaliar situações novas ou recorrentes e tomar decisões imediatas ou deixá-las para mais tarde, para que com mais conhecimento, façam escolhas mais conscientes e, portanto, com mais chances de acertá-las.

Métodos ágeis estimulam a adaptação do processo incrementalmente usando a experiência e o conhecimento adquiridos como parte dos insumos para alcançar melhores resultados. Durante nossas experiências, identificamos claramente a necessidade de mudar várias das práticas após usá-las em uma ou mais iterações. Práticas que inicialmente se mostraram benéficas, com o tempo, foram 
descartadas por deixarem de acrescentar ao projeto ou porque foram substituídas por outras mais eficientes. Isso alertou as equipes para a importância do aprendizado contínuo. Para nós, confirmou a hipótese de que cada projeto precisa de um grupo adequado de práticas. Mais do que isso, cada projeto precisa constantemente renovar suas práticas pois, para cada momento, haverá um conjunto delas que será mais produtivo.

\subsection{Contribuições}

Dentre as contribuições deste trabalho, podemos destacar:

- Investigação dos principais modelos de desenvolvimento de software utilizados na indústria e pesquisados pela academia. O Capítulo 2 reúne o resultado desta pesquisa, mostrando as soluções que cada abordagem oferece para a problemática do desenvolvimento de sistemas.

- Aplicação de metodologias ágeis em quatro projetos de desenvolvimento de software. Juntos esses projetos nos proveram mais de quatro anos de experiência com desenvolvimento ágil e contato com cerca de 105 indivíduos, sendo aproximadamente 70 desenvolvedores e 35 clientes, gerentes e diretores envolvidos com os projetos. Além destes, ainda mantivemos contato com algumas dezenas de usuários que nos forneceram feedback durante as implementações.

- Relatos sobre os quatro projetos que selecionamos como caso de estudo para este trabalho: um dentro da universidade, um no setor público e dois na indústria, sendo um deles em uma empresa consolidada no mercado financeiro e outro em uma startup.

- Relatos sobre condução da equipe de desenvolvimento da primeira empresa brasileira de "Web 2.0 " a receber um investimento de capital de risco.

- Proposição de 22 pontos relevantes no desenvolvimento de software, divididos nas categorias que definimos como: Estratégica, Motivacional e de Desempenho. Cada um deles pode ser tratado como uma prática que pode ser aplicada individualmente em qualquer projeto de desenvolvimento de software para fortalecer um ou mais valores ágeis.

- Abordagem de Engenharia de Software que considera também as questões ligadas ao lado humano dos projetos de desenvolvimento de software. 


\subsection{Trabalhos Futuros}

Os resultados obtidos neste trabalho foram conseguidos a partir do estudo de quatro projetos em ambientes não-controlados, os quais nos permitiram a identificação de melhorias no rendimento da equipe a partir da introdução de novas práticas. Dada a dificuldade em conduzir experimentos com equipes de desenvolvimento em ambientes controlados, novas pesquisas podem ser realizadas relatando mais casos de uso de métodos ágeis para que os resultados possam ser reforçados e novas conclusões possam ser obtidas a partir de uma base histórica de projetos. Além disso, pesquisas em ambientes controlados e comparações sistemáticas com métodos tradicionais seriam excelentes complementos a este trabalho.

Novas pesquisas podem ser realizadas para aprofundar as conclusões indicadas neste trabalho. Relatos e análises quantitativas da aplicação das práticas que propusemos podem ser conduzidas utilizando métricas de acompanhamento que as relacionem com a evolução do projeto e com a qualidade do código. Outras pesquisas que proponham e verifiquem a validade de novas práticas também seriam interessantes. Pois, as práticas que propusemos aqui, juntamente com as de outros trabalhos da literatura, podem ser agrupadas para constituir um portifólio de práticas ágeis, ao qual as equipes de desenvolvimento possam recorrer para selecionar aquelas práticas que mais se adequam ao contexto do projeto.

Acreditamos que fatores motivacionais e as relações interpessoais entre os membros da equipe exercem forte influência na evolução do projeto. Portanto, uma linha de pesquisa pode envolver estudos aprofundados no campo da psicologia relacionando fatores emocionais em metodologias adaptativas (ágeis) e em metodologias prescritivas (tradicionais) para verificar a existência de correlações com a qualidade do software e o número de erros encontrados. Outra possibilidade, também da linha da psicologia, é a medição individual das práticas que propusemos na categoria Motivacional, utilizando técnicas e indicadores apropriados que meçam os seus efeitos sob o ponto de vista do indivíduo. 


\section{Referências Bibliográficas}

$\left[\mathrm{ABB}^{+} 98\right] \quad$ Ann Anderson, Ralph Beattie, Kent Beck, David Bryant, Marie DeArment, Martin Fowler, Margaret Fronczak, Rich Garzaniti, Dennis Gore, Brian Hacker, Chet Hendrickson, Ron Jeffries, Doug Joppie, David Kim, Paul Kowalsky, Debbie Mueller, Tom Murasky, Richard Nutter, Adrian Pantea, and Don Thomas. Chrysler goes to "extremes". Distributed Computing, 1(10):24-28, october 1998.

[ANV05] Scott Ambler, John Nalbone, and Michael Vizdos. The Enterprise Unified Process: Extending the Rational Unified Process. Prentice Hall Professional, 2005.

[BA04] Kent Beck and Cynthia Andres. Extreme Programming Explained: Embrace Change. Addison Wesley Professional, 2nd edition, 2004.

$\left[\mathrm{BAB}^{+} 00\right]$ Barry Boehm, Chris Abts, A. Brown, Sunita Chulani, Bradford Clark, Ellis Horowitz, Ray Madachy, Donald Reifer, and Bert Steece. Software Cost Estimation with Cocomo II. Prentice Hall PTR, 2000.

$\left[\mathrm{BBvB}^{+} 01\right]$ Kent Beck, Mike Beedle, Arie van Bennekum, Alistair Cockburn, Ward Cunningham, Martin Fowler, James Grenning, Jim Highsmith, Andrew Hunt, Roland Jeffries, Jon Kern, Brian Marick, Robert C. Martin, Steve Mellor, Ken Schwaber, Jeff Sutherland, and Dave Thomas. Manifesto for Agile Software Development, 2001. http://www. agilemanifesto.org, último acesso: 22/12/2007.

[Bec96] Kent Beck. Smalltalk: best practice patterns. Prentice-Hall, 1996.

[Bec99] Kent Beck. Extreme Programming Explained: Embrace Change. Addison-Wesley, 1999.

[Bec03] Kent Beck. Test-Driven Development: by example. Addison-Wesley, 2003.

[BF01] Kent Beck and Martin Fowler. Planning Extreme Programming. Addison-Wesley, 2001.

[BH94] Sam Bayer and Jim Highsmith. RADical software development. American Programmer, 7(6):35-42, june 1994. 
[Bin99] Robert V. Binder. Testing Object-Oriented Systems: Models, Patterns, and Tools. Object Technology Series. Addison Wesley, 1999.

[BJFG04] Junior Barrera, Roberto Marcondes Cesar Junior, João Eduardo Ferreira, and Marco Dimas Gubitoso. An environment for knowledge discovery in biology. Journal of Computers in Biology and Medicine, 34(5):427-447, July 2004.

$\left[\mathrm{BMR}^{+} 96\right] \quad$ Frank Buschmann, Regine Meunier, Hans Rohnert, Peter Sommerlad, and Michael Stad. Pattern-Oriented Software Architecture - A System of Patterns. John Wiley Press, 1996.

[Boe86] Barry Boehm. A spiral model of software development and enhancement. ACM SIGSOFT Software Engineering Notes, 11(4):14-24, 1986.

[Boe00] Barry Boehm. Requirements that handle IKIWISI, COTS, and rapid change. Computer, 33(7):99-102, 2000.

[BW79] Thomas Berrisford and James Wetherbe. Heuristic Development: A Redesign of Systems Design. MIS Quarterly, 3(1):11-19, 1979.

[Can81] Richard Canning. Developing systems by prototyping. EDP Anal. 19, 9:1-14, 1981.

[CdLL99] Peter Coad, Jeff de Luca, and Eric Lefebvre. Java Modeling Color with UML: Enterprise Components and Process. Prentice Hall, 1999.

[CKS03] Mary Beth Chrissis, Mike Konrad, and Sandy Shrum. CMMI: Guidelines for Process Integration and Product Improvement. Addison-Wesley Professional, 2003.

[CLW00] Larry L. Constantine, Lucy A.D. Lockwood, and Larry Wood. Software for use: A practical guide to the models and methods of usage-centered design. SIGCHI Bulletin, $32(1): 111,2000$.

[Coc98] Alistair Cockburn. Surviving object-oriented projects. Addison-Wesley, 1998.

[Coc00] Alistair Cockburn. Selecting a project's methodology. IEEE Software, 17(4):64-71, July/August 2000.

[Coc04] Alistair Cockburn. Crystal Clear: A Human-Powered Methodology for Small Teams. Addison-Wesley, 2004.

[Coc06] Alistair Cockburn. Agile Software Development. Addison Wesley, 2 edition, 2006.

[Coh06] Mike Cohn. Agile Estimating and Planning. Prentice Hall, 2006. 
[Con] DSDM Consortium. Official DSDM Overview Presentation. www.dsdm.org/ knowledgebase/download/100/official_dsdm_overview_presentation_pdf.pdf, último acesso: 31/01/2008.

[Coo04] Alan Cooper. The Inmates Are Running the Asylum: Why High Tech Products Drive Us Crazy and How to Restore the Sanity. Sams Publishing, 2004.

[CS06] Jan Chong and Rosanne Siino. Interruptions on software teams: a comparison of paired and solo programmers. In Proceedings of the 20th Anniversary Conference on Computer Supported Cooperative Work (CSCW'06), pages 29-38. ACM, 2006.

[CW93] Kim B. Clark and Steven C. Wheelwright. Managing New Product and Process Development: Text and Cases. The Free Press, 1993.

[CW01] Alistair Cockburn and Laurie Williams. The costs and benefits of pair programming. Extreme Programming Examined, pages 223-243, 2001.

[Dan05] Ajay Danait. Agile offshore techniques - a case study. In Proceedings of the 6th International Conference on eXtreme Programming and Agile Processes in Software Engineering (XP'2005), pages 214-217. Springer, 2005.

[Dem86] William Eduwards Deming. Out of the Crisis: Quality, Productivity, and Competitive Position. Cambridge University Press, 1986.

[DeM01] Tom DeMarco. Slack: Getting Past Burnout, Busywork, and the Myth of Total Efficiency. Broadway Books, 2001.

[DK04] Carsten Dogs and Timo Klimmer. An Evaluation of the Usage of Agile Core Practices. Master's thesis, Blekinge Institute of Technology, Sweden, 2004.

[DL99] Tom DeMarco and Timothy Lister. Peopleware: productive projects and teams. Dorset House Publishing, 2nd edition, 1999.

[DSD] DSDM Consortium. http://www.dsdm.org, último acesso: 31/01/2008.

[Eva03] Gary Evans. Agile RUP for non-object-oriented projects. The Rational Edge, 2003. http://download.boulder.ibm.com/ibmdl/pub/software/dw/ rationaledge/sep03/m_rupagility_ge.pdf.

[FaK05] Oskar Fransson and Patrick af Klercker. Agile Software Development in Sweden: A quantitative study of developers' satisfaction and their attitude towards agile thinking. Master's thesis, Jönköping University, Sweden, June 2005. 
[FB99] João Eduardo Ferreira and Gisele Busichia. Database modularization design for the construction of flexibleinformation systems. In Proceedings of the International Symposium on Database Engineering and Applications (IDEAS'99), pages 415-422, 1999.

[FBB $\left.{ }^{+} 99\right] \quad$ Martin Fowler, Kent Beck, John Brant, William Opdyke, and Don Roberts. Refactoring: Improving the Design of Existing Code. Addison-Wesley Professional, 1999.

[FF00] J. E. Ferreira and M. Finger. Controle de concorrência e distribuição de dados: Teoria clássica, suas limitações e extensões modernas. XII Escola de Computação, pages 7383 , July 2000.

$\left[\mathrm{FGF}^{+} 04\right] \quad$ Alexandre Freire, Alfredo Goldman, Carlos Eduardo Ferreira, Christian Asmussen, and Fabio Kon. Mico - university schedule planner. In Anais do $5^{\circ}$ Workshop sobre Software Livre (WSL 2004), pages 147-150, 2004.

[FGK05] Alexandre Freire, Francisco Gatto, and Fabio Kon. Cigarra - a peer-to-peer cultural grid. In Anais do $6^{\circ}$ Workshop sobre Software Livre (WSL 2005), page 177-183, 2005.

[FKT05] Alexandre Freire, Fabio Kon, and C. Torteli. XP South of the Equator: An eXPerience Implementing XP in Brazil. In Proceedings of the 6th International Conference on Extreme Programming and Agile Processes in Software Engineering (XP'2005), pages 18-23. Springer, 2005.

[Fre07] Alexandre Freire. Reflexões sobre o ensino de metodologias ágeis na academia, na indústria e no governo. Master's thesis, Instituto de Matemática e Estatística da Universidade de São Paulo - IME/USP, 2007.

$\left[\mathrm{GBL}^{+} 04\right] \quad$ Fred Grossman, Joseph Bergin, D. Leip, Susan Merritt, and O. Gotel. One XP experience: Introducing agile (XP) software development into a culture that is willing but not ready. In Proceedings of the 2004 Conference of the Centre for Advanced Studies on Collaborative research (CASCON '04), pages 242-254. IBM Press, 2004.

[GHJV95] Erich Gamma, Richard Helm, Ralph Johnson, and John Vlissides. Design Patterns: Elements of Reusable Object-Oriented Software. Addison-Wesley, 1995.

[Gil76] Tom Gilb. Software Metrics. Chartwell-Bratt, 1976.

[Gil85] Tom Gilb. Evolutionary Delivery versus 'Waterfall Model'. ACM Sigsoft Software Requirements Engineering Notes, 10(3):49-61, 1985.

[Gil88] Tom Gilb. Principles of Software Engeneering Management. Addison-Wesley, 1988.

[Gil89] Tom Gilb. A planning language (a planguage). In Proceedings of the APL as a Tool of Thought (APL'89), volume 19, pages 169-177. ACM, 1989. 
[GKdSeSY04] Alfredo Goldman, Fabio Kon, Paulo J. da Silva e Silva, and Joseph Yoder. Being extreme in the classroom: experiences teaching XP. Journal of the Brazilian Computer Society, 10(2):1-17, 2004.

[GM94] M. Gell-Mann. Complex Adaptive Systems. Complexity: Metaphors, Models, and Reality, 19:17-45, 1994.

[GM01] Athula Ginige and San Murugesan. Guest Editors' Introduction: Web Engineering-An Introduction. IEEE MultiMedia, 08(1):14-18, 2001.

[Har98] MJ Harry. Six Sigma: A Breakthrough Strategy for Profitability. Quality progress, 31(5):60-64, 1998.

[Hig97] Jim Highsmith. Messy, exciting, and anxiety-ridden: Adaptative software development. American Programmer, 10(1), january 1997.

[Hig00] Jim Highsmith. Adaptive Software Development: A Collaborative Approach to Managing Complex Systems. Dorset House, 2000.

[Hig04] Jim Highsmith. Agile Project Management: Creating Innovative Products. AddisonWesley, 2004.

[Hoi03] Jesper Hoick. 4 perspectives on Web information systems. In Proceedings of the 36th Annual Hawaii International Conference on System Sciences (HICSS'03), page 8, 2003.

[Ins04] Project Management Institute. PMBOK - Project Management Body of Knowledge. PMI - Project Management Institute, 3 edition, 2004.

[JAH00] Roland E. Jeffries, Ann Anderson, and Chet Hendrickson. Extreme Programming Installed. Addison-Wesley, 2000.

[JBR99] Ivar Jacobson, Grady Booch, and J. Rumbaugh. The Unified Software Development Process. Addison-Wesley, 1999.

[JCJO92] Ivar Jacobson, Magnus Christerson, Patrik Jonsson, and Gunnar Overgaard. ObjectOriented Software Engineering: A Use Case Driven Approach. Addison Wesley Professional, 1992.

[JJ86] G. Douglas Jenkins Jr. Financial incentives. Generalizing from laboratory to field settings: Research findings from Industrial-Organizational Psychology, Organizational Behavior, and Human Resource Management, pages 167-180, 1986.

[JM07] Roland Jeffries and Grigori Melnik. TDD - The Art of Fearless Programming. IEEE Software, 24(3):24-30, 2007. 
[JMGS98] G. Douglas Jenkins, A. Mitra, N. Gupta, and J. D. Shaw. Are financial incentives related to performance? A meta-analytic review of empirical research. Journal of Applied Psychology, 83(5):777-787, 1998.

[JNS07] Ivar Jacobson, Pan Wei Ng, and Ian Spence. Enough Process - Let's Do Practices. Journal of Object Technology, pages 41-66, July-August 2007.

[Joh02] Jim Johnson. ROI, it's your job. In Keynote Speech at 3rd International Conference on eXtreme Programming and Agile Processes in Software Engineering (XP'2002), May 2002.

[Jon96] Capers Jones. Software defect-removal efficiency. Computer, 29(4):94-95, 1996.

[JZ03] Bent Jensen and Alex Zilmer. Cross-Continent Development Using Scrum and XP. In Proceedings of the 4th International Conference on eXtreme Programming and Agile Processes in Software Engineering (XP'2003), pages 25-29. Springer, 2003.

[KA96] Christer Karlsson and Pär Ahlstrom. The difficult path to lean product development. Journal of Product Innovation Management, 13(4):283-295, 1996.

[Kee93] Christopher Keene. Using objects with relational databases. In Proceedings of $C_{++}$ World. SIGS Conferences, 1993.

[Ker01] Norman Kerth. Project Retrospectives: A Handbook for Team Reviews. Dorset House Publishing, 2001.

[Ker04] Joshua Kerievsky. Refactoring to Patterns. Addison-Wesley Professional, 2004.

[KH93] James Kerr and Richard Hunter. Inside RAD: How to Build Fully Functional Computer Systems in 90 Days or Less. McGraw-Hill, 1993.

[KJ95] Raymond Kehoe and Alka Jarvis. ISO 9000-3: A Tool for Software Product and Process Improvement. Springer, 1995.

[KK03] Per Kroll and Philippe Kruchten. The Rational Unified Process Made Easy. AddisonWesley, 2003.

[KM06] Per Kroll and Bruce MacIsaac. Agility and Discipline Made Easy: Practices from OpenUP and RUP. Addison-Wesley Professional, 2006.

[Kni07] Henrik Kniberg. Scrum and XP from the Trenches. InfoQ Enterprise Software Development Series, 2007.

[Koh93] Alfie Kohn. Why incentive plans cannot work. Harvard Business Review, 71(5):54-63, 1993. 
[KR02] Jonna Kalermo and Jenni Rissanen. Agile software development in theory and practice. Master's thesis, University of Jyväskylä, Finland, 2002.

[Kru03] Philippe Kruchten. The Rational Unified Process: An Introduction. Addison-Wesley Professional, 3 edition, 2003.

[KSTT84] Noriaki Kano, Nobuhiku Seraku, Fumio Takahashi, and Shin-ichi Tsuji. Attractive quality and must-be quality. The Journal of the Japanese Society for Quality Control, 14(2):39-48, 1984.

[Lar04] C. Larman. Agile and Iterative Development: A Manager's Guide. Addison-Wesley Professional, 2004.

[LC05] Amy Law and Raylene Charron. Effects of agile practices on social factors. In Proceedings of the Workshop on Human and Social Factors of Software Engineering (HSSE'05), volume 30, pages 1-5. ACM Press, 2005.

[Lip04] Martin Lippert. Towards a Proper Integration of Large Refactorings in Agile Software Development. In Proceedings of the 5th International Conference on eXtreme Programming and Agile Processes in Software Engineering (XP'2004), pages 113-122. Springer, 2004.

[Mar91] James Martin. Rapid Application Development. Macmillan Publishing Co., 1991.

[MAR07] Library of Congress - MARC Standards, 2007. http://www.loc.gov/marc, último acesso em: 12/06/2007.

[Mas54] Abraham Harold Maslow. Motivation and Personality. Harper \& Row, 1954.

[MDL87] H. D. Mills, M. Dyer, and R. C. Linger. Cleanroom Software Engineering. IEEE Software, 4(5):19-25, September 1987.

[Mer] Peter Merel. Extreme Hour. http://c2.com/cgi/wiki?ExtremeHour, último acesso: $22 / 12 / 2007$.

[MS95] Don Millington and Jennifer Stapleton. Developing a RAD standard. IEEE Software, 12(5):54-55, 1995.

[Nos98] John T. Nosek. The case for collaborative programming. Communications of the ACM, 41(3):105-108, 1998.

[NT86] Ikujiro Nonaka and Hirotaka Takeuchi. The new new product development game. Harvard Business Review, 64(1):137-146, 1986. 
[Ohn88] Taiichi Ohno. Toyota Production System: Beyond Large-Scale Production. Productivity Press, 1988.

[PA06] John Pruitt and Tamara Adlin. The Persona Lifecycle: Keeping People in Mind Throughout Product Design. Morgan Kaufmann, 2006.

[PF02] Stephen Palmer and John Mac Felsing. A Practical Guide to Feature Driven Development. Prentice Hall, 2002.

[PP03] Mary Poppendieck and Tom Poppendieck. Lean Software Development: An Agile Toolkit. Addison-Wesley Professional, 2003.

[PP05] Minna Pikkarainen and Ulla Passoja. An Approach for Assessing Suitability of Agile Solutions: A Case Study. In Proceedings of the 6th International Conference on eXtreme Programming and Agile Processes in Software Engineering (XP'2005), pages 18-23. Springer, 2005.

[PP06] Mary Poppendieck and Tom Poppendieck. Implementing Lean Software Development: From Concept to Cash. Addison-Wesley Professional, 2006.

[Pre04] Roger S. Pressman. Software Engineering: a Practitioner's Approach. McGraw-Hill, 6th edition, 2004.

[Rat] Rational Unified Process. http://www.wthreex.com/rup/, último acesso: $31 / 01 / 2008$.

[Roy70] Winston W. Royce. Managing the development of large software systems. In Proceedings of the IEEE WESCON, pp. 1-9, volume 26, 1970. Reprinted in Proceedings of the International Conference on Software Engineering (ICSE) 1989, ACM Press, pp. 328-338.

[RvW07] I. Richardson and C. von Wangenheim. Guest editors' introduction: Why are small software organizations different? IEEE Software, 24(1):18-22, January 2007.

[Sat07] Danilo Toshiaki Sato. Uso eficaz de métricas em métodos ágeis de desenvolvimento de software. Master's thesis, Instituto de Matemática e Estatística da Universidade de São Paulo - IME/USP, 2007.

[SB02] Ken Schwaber and Mike Beedle. Agile Software Development with Scrum. PrenticeHall, 2002.

$\left[\mathrm{SBB}^{+} 02\right] \quad$ Forrest Shull, Vic Basili, Barry Boehm, A.Winsor Brown, Patricia Costa, Mikael Lindvall, Dan Port, Ioana Rus, Roseanne Tesoriero, and Marvin Zelkowitz. What we have learned about fighting defects. In Proceedings of the 8th International Software Metrics Symposium. Ottawa, Canada., pages 249-258. IEEE Computer Society, 2002. 
$\left[\mathrm{SBB}^{+} 06\right]$ Danilo Sato, Dairton Bassi, Mariana Bravo, Alfredo Goldman, and Fabio Kon. Experiences tracking agile projects: an empirical study. Journal of the Brazilian Computer Society, Special Issue on Experimental Software Engineering, 12(3):45-64, December 2006.

[SBG07] Danilo Sato, Dairton Bassi, and Alfredo Goldman. Extending extreme programming with practices from other methodologies. In Proceedings of the 1st Workshop on Rapid Application Development (WDRA'07) in the Brazilian Symposium of Software Quality (SBQS'07), 2007.

[Sch95] Ken Schwaber. The Scrum development process. In Proceedings of the 10th Annual ACM Conference on Object Oriented Programming Systems, Languages, and Applications (OOPSLA'95), Austin, Texas, USA, pages 117-134, 1995.

[Sch04] Ken Schwaber. Agile Software Development with Scrum. Microsoft Press, 2004.

[Scr] Scrum Alliance. http://www.scrumalliance.org, último acesso: 31/01/2008.

[She80] W.A. Shewhart. Economic Control of Quality of Manufactured Product. ASQ Quality Press, 1980.

[Som06] Ian Sommerville. Software Engineering. Addison-Wesley, 8th edition, 2006.

[SR07] Helen Sharp and Hugh Robinson. Collaboration and co-ordination in mature eXtreme programming teams. International Journal of Human-Computer Studies, 2007. http: //dx.doi.org/doi:10.1016/j.ijhcs.2007.10.004.

[SS03] DSDM Consortium Stapleton and Jennifer Stapleton. DSDM: A Framework for Business-Centered Development. Addison-Wesley Longman Publishing Co., Inc., Boston, MA, USA, 2003.

[Sta94] Standish Group. The CHAOS Report, 1994. http://www.standishgroup.com/ sample_research/chaos_1994_1.php, último acesso: 31/01/2008.

[Sut00] Stanley M. Sutton. The role of process in software start-up. IEEE Software, 17(4):33$39,2000$.

[SVBP07] Jeff Sutherland, Anton Viktorov, Jack Blount, and Nikolai Puntikov. Distributed Scrum: Agile project management with outsourced development teams. In Proceedings of the 40th Annual Hawaii International Conference on System Sciences (HICSS '07), pages 274-284. IEEE Computer Society, 2007.

[Tel05] Vinícius Manhães Teles. Um estudo de caso da adoção das práticas e valores do extreme programming. Master's thesis, Universidade Federal do Rio de Janeiro, 2005. 
[WBA02] N. Wallace, P. Bailey, and N. Ashworth. Managing XP with Multiple or Remote Customers. In Proceedings of the 3rd International Conference on eXtreme Programming and Agile Processes in Software Engineering (XP'2002), 2002.

[WJR90] James Womack, Daniel Jones, and Daniel Roos. The Machine that Changed the World. Scribner, 1990.

[WK02] Laurie Williams and Robert Kessler. Pair Programming Illuminated. Addison Wesley, 2002 .

[WKCJ00] Laurie Williams, Robert R. Kessler, Ward Cunningham, and Ron Jeffries. Strengthening the case for pair programming. IEEE Software, 17(4):19-25, 2000.

[WRA ${ }^{+}$04] Kival C. Weber, Ana Regina Rocha, Angela Alves, Arnaldo M. Ayala, Austreglésilo Gonçalves, Benito Paret, Clênio Salviano, Cristina F. Machado, Danilo Scalet, Djalma Petit, and Eratóstenes Araújo. Modelo de Referência para Melhoria de Processo de Software: uma abordagem brasileira. In $30^{a}$ Conferência Latino-Americana de Informática (CLEI'2004), 2004.

[Wue02] Klaus Wuestefeld. Customer proxy and libero. E-mail personal communication, 34, September 2002.

[ZMMW01] Jörg Zettel, Frank Maurer, Jürgen Münch, and Les Wong. LIPE: a Lightweight Process for E-Business Startup Companies Based on Extreme Programming. In Proceedings of the 3rd International Conference on Product-Focused Software Process Improvement (PROFES 2001), volume 2188 of Lecture Notes in Computer Science, pages 255-271. Springer, 2001. 